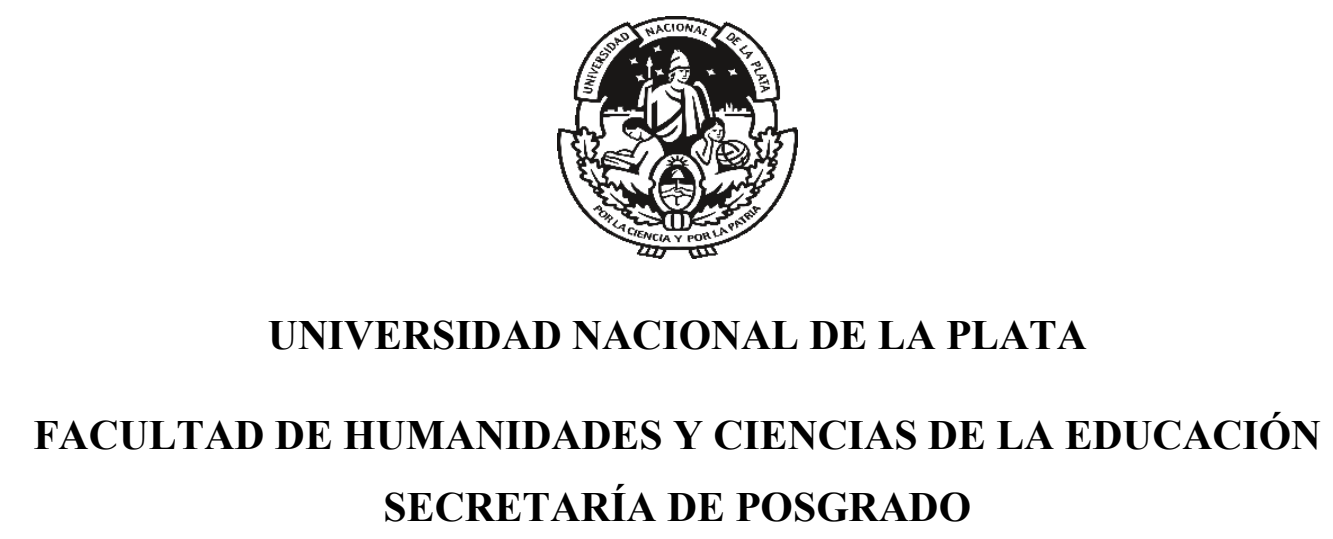

Tesis de Doctorado

\title{
LIDERESAS CAMPESINAS AGREMIADAS EN LA FEDERACIÓN NACIONAL SINDICAL UNITARIA AGRARIA (FENSUAGRO)
}

IDENTIDAD Y RESISTENCIA ANTE LAS POLÍTICAS AGRARIAS DE LOS TRES ÚLTIMOS GOBIERNOS NACIONALES

(COLOMBIA, 2002-2020)

TESISTA: LUZ NANCY SOTOMAYOR TORRES

DIRECTORA: Dr. SOLEDAD LEMMI

CO-DIRECTOR: Dr. MAURICIO ARCHILA

Junio 2021 


\section{INDICE}

LIDERESAS CAMPESINAS AGREMIADAS EN LA FEDERACIÓN NACIONAL SINDICAL UNITARIA

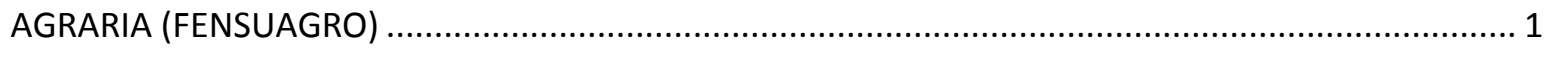

IDENTIDAD Y RESISTENCIA ANTE LAS POLÍTICAS AGRARIAS DE LOS TRES ÚLTIMOS GOBIERNOS

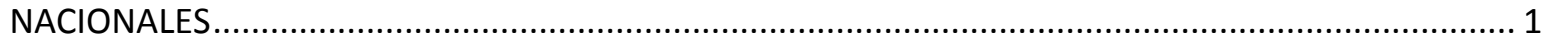

(COLOMBIA, 2002-2020)

LIDERESAS CAMPESINAS AGREMIADAS EN LA FEDERACIÓN NACIONAL SINDICAL UNITARIA

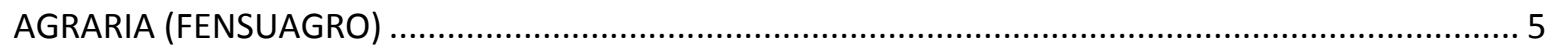

IDENTIDAD Y RESISTENCIA ANTE LAS POLÍTICAS AGRARIAS DE LOS TRES ÚLTIMOS GOBIERNOS

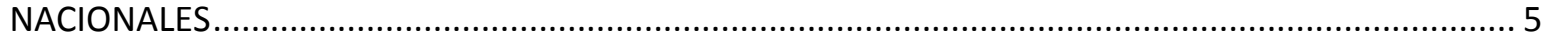

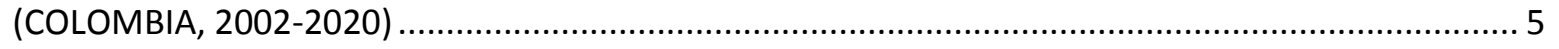

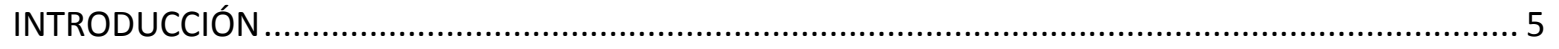

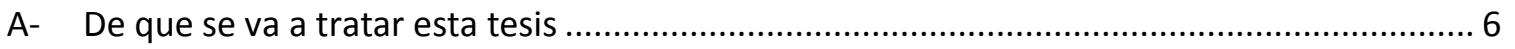

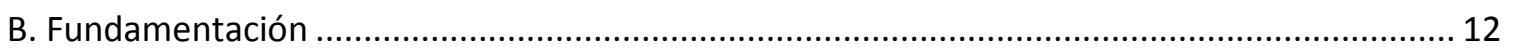

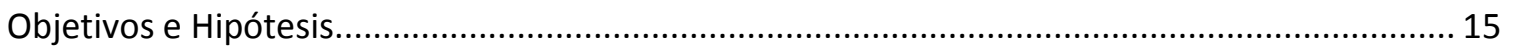

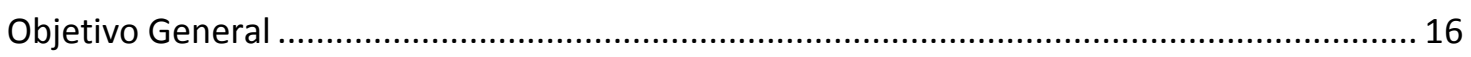

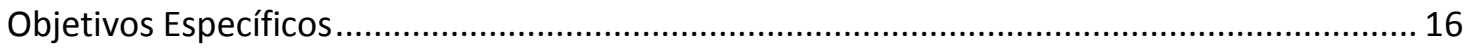

Hipótesis:

Marco teórico, metodología y fuentes de información ................................................................ 17

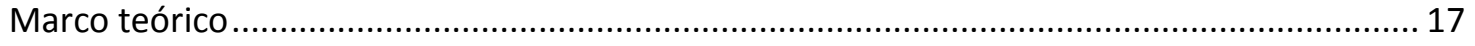

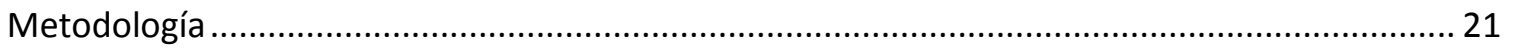

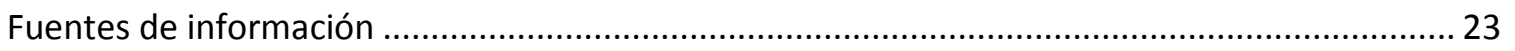

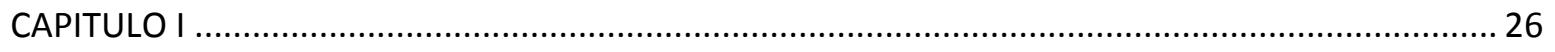

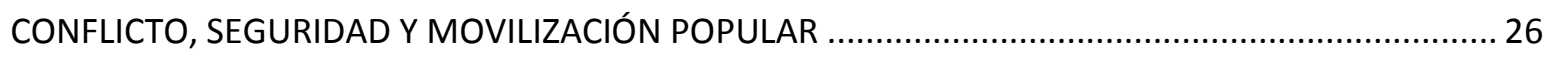

DE LA SEGURIDAD DEMOCRÁTICA AL PROCESO DE PAZ DE LA HABANA (2002-2017) ................... 26

Plan Colombia y Seguridad Democrática: estrategias del primer gobierno de Álvaro Uribe ....... 27

Desplazamiento forzado: consecuencia de la confrontación y estrategia de guerra ..................... 36

Tabla 1. Países con mayores índices de desplazamiento interno ............................................ 39

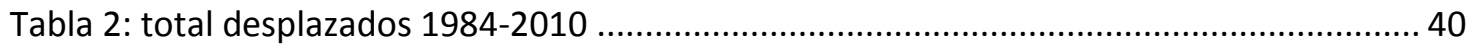

Tabla 3: personas desplazadas de manera individual y de forma masiva ............................... 41

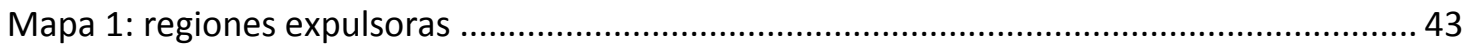

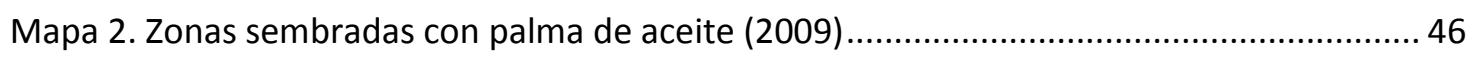

Mapa 3. Desplazamientos realizados por paramilitares entre 1997 y 2009 ............................. 46 
Diálogos con los paramilitares y desmovilización: se renueva el ciclo de violencia 49

Tabla 4: masacres cometidas durante los diálogos de paz con los .......................................... 51

Pactos y parapolítica: estrategia para "refundar la patria" ........................................................... 56

Juan Manuel Santos y El Proceso de Paz. ¿̇Inicio de un nuevo período? ........................................63

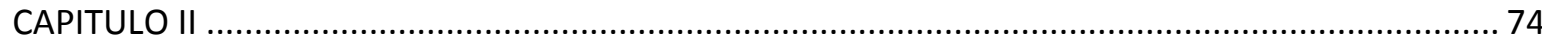

MUJER RURAL, POLÍTICAS PÚBLICAS Y ORGANIZACIÓN CAMPESINA ........................................ 74

2.1. Organización campesina y lucha por la tierra: breve recuento histórico .............................. 74

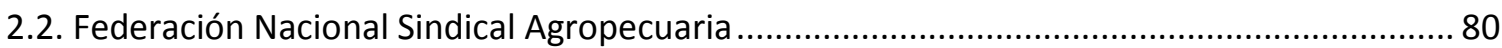

Imagen 1. Mural en la sede de FENSUAGRO, Viotá-Cundinamarca............................................ 84

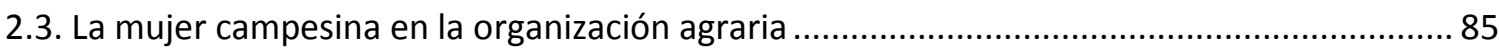

Tabla 5. Datos poblacionales en las zonas rurales .............................................................. 91

Mapa 4. Movilización campesina en Colombia.................................................................. 103

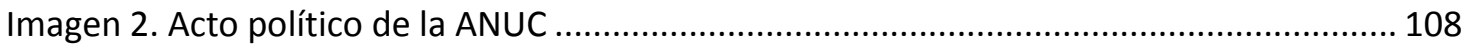

2.4. Condiciones jurídicas en Colombia para la mujer rural.................................................... 109

Tabla 6. Políticas públicas y mujer rural en Colombia............................................................ 117

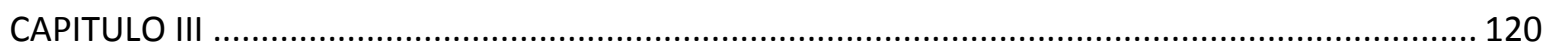

MUJERES LIDERESAS Y CAMPESINAS DE FENSUAGRO: APUESTA DE RESISTENCIA ...................... 120

3.1. ¿Quiénes son las mujeres de esta historia? .................................................................... 120

3.2. Ser mujer y ser campesina, un reto........................................................................ 131

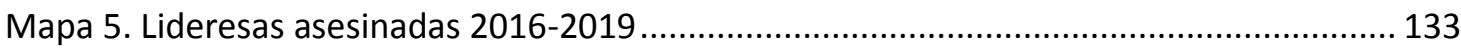

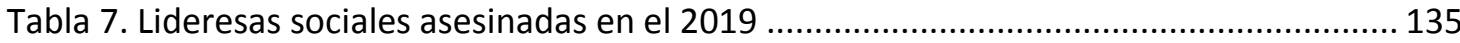

3.3. Voces de resistencia, resiliencia y empoderamiento de lideresa campesinas en Colombia 139

Tabla 8. Ingreso de las Mujeres Lideres Campesinas a FENSUAGRO ....................................... 140

Tabla 9. Machismo como elemento limitante de la participación política ............................. 147

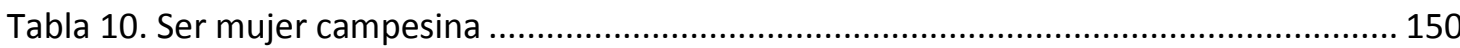

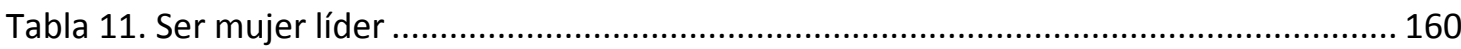

Tabla 12. Empoderamiento de las mujeres líderes campesinas de FENSUAGRO ..................... 166

Mapa 6. Palabras que asomaban en las entrevistas a $\mathrm{MCL}$............................................... 172

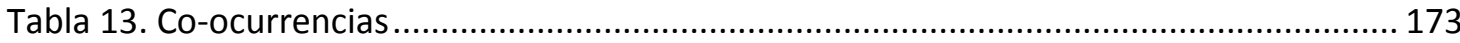

Tabla 14. Lideresas sociales asesinadas en el año 2020.................................................... 175

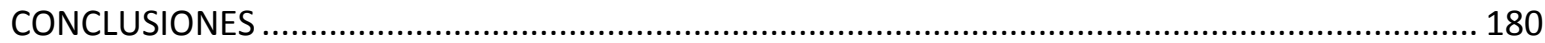

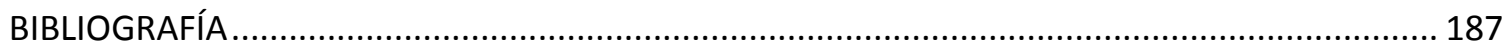




\section{LIDERESAS CAMPESINAS AGREMIADAS EN LA FEDERACIÓN NACIONAL SINDICAL UNITARIA AGRARIA (FENSUAGRO)}

IDENTIDAD Y RESISTENCIA ANTE LAS POLÍTICAS AGRARIAS DE LOS TRES ÚLTIMOS GOBIERNOS NACIONALES

(COLOMBIA, 2002-2020)

\section{INTRODUCCIÓN}

“...en el noble tumulto, una mujer de oratoria vibrante,

Ana Betancourt, anuncia que el fuego de la libertad y el ansia del martirio no calientan con más viveza el alma del hombre que de la mujer “

“... es incompleta la victoria cuando no se mueve el corazón de la mujer.

Él es la medicina; él es el milagro; él es el triunfo".

Ana Betancourt 


\section{A- De que se va a tratar esta tesis}

Esta investigación versará sobre el papel desempeñado por las mujeres campesinas colombianas lideresas en sus comunidades, agremiadas en una organización sindical agraria denominada Federación Nacional Sindical Unitaria Agropecuaria (FENSUAGRO) y sus luchas en un período de intenso conflicto armado interno (20022020). En Colombia al igual que en muchos países latinoamericanos la inequidad de género se ha visto presente en muchos campos, pero donde más se ha hecho evidente es en el sector rural. La mujer campesina ha sido, a lo largo de la historia, una víctima antes y durante el conflicto armado.

En los últimos veinte años se han venido produciendo muchos movimientos a favor de la mujer, hecho mismo que ha servido para presionar al gobierno para decretar algunas normas para proteger a la mujer en general. Estas normas han sido reglamentadas por medio de la Ley 1257 de 2008 sobre equidad de género. Ahora bien, estas normas se extienden a todas las mujeres no importa su condición en particular, pero no abarcan problemáticas específicas que afronta la mujer campesina, que se encuentra en muchas ocasiones en medio del conflicto armado. Sin embargo, podemos decir que muchas de estas mujeres se han convertido en parte activa en movimientos de resistencia para reclamar y hacer valer sus derechos.

De acuerdo con la Comisión Histórica de la Verdad y sus Víctimas creada en el marco de los acuerdos de paz de La Habana, Cuba (2016), existe cierta dificultad para rastrear el origen del conflicto armado en Colombia e identificar sus características originarias. Sin 
embargo, académicos como Darío Fajardo (2014) y Alfredo Molano (2014) afirman que el origen del conflicto puede datarse desde 1920 con las primeras expresiones de luchas por la tierra y la reforma agraria en zonas del Tolima ${ }^{1}$, Sumapaz $^{2}$ y el Cauca $^{3}$. Eventos como la Masacre de las Bananeras en $1928^{4}$, el fracaso del primer intento de reforma agraria en $1936^{5}$ y la muerte de Jorge Eliécer Gaitán en $1948^{6}$ se convirtieron en tres elementos centrales del conflicto armado interno. De esta manera, el conflicto se configuró como consecuencia de varios factores: la acumulación de tierras utilizada por élites rurales y terratenientes para establecerse en el poder político, la exclusión política y social generada contra campesinos pobres y el inicio del Frente Nacional ${ }^{7}$, posterior al asesinato de Gaitán.

Como se evidencia, el conflicto armado tiene su génesis en una estructura rural inequitativa, que ha permitido la acumulación de tierras en manos de terratenientes, la expansión de la frontera agrícola mediante colonizaciones armadas y uno de los índices de desplazamientos más altos del mundo: 0,87 según el Instituto Geográfico Agustín Codazzi ${ }^{8}$. De esta manera, se puede afirmar que las organizaciones sindicales y agrarias en un contexto como el colombiano no son formas de acción colectiva espontánea ni únicamente masculinas. Como lo destaca Donny Meertens (1994), la relación entre mujer, género y conflicto armado

\footnotetext{
${ }^{1}$ Departamento ubicado en la zona cetro del país.

${ }^{2}$ Región que abarca parte de la región centro y oriente del país.

${ }^{3}$ Región occidental del país.

${ }^{4}$ Matanza de trabajadores de la United Fruit Company ocurrida en el municipio de Ciénaga, departamento del Magdalena entre el 5 y 6 de diciembre de 1928, ordenada por el entonces presidente conservador Miguel Abadía Méndez.

${ }^{5}$ La ley 200 de tierras promulgada por el presidente liberal Alfonso López Pumarejo.

${ }^{6}$ Situación que generaría el Bogotazo y la primera ola de La Violencia.

${ }^{7}$ Período de 16 años en el que se alternaban el poder el Partido Liberal y el Partido Conservador, excluyendo otras corrientes políticas.

8 Ver: https://www.eltiempo.com/economia/sectores/desigualdad-en-la-propiedad-de-la-tierra-en-colombia32186.
} 
ha constituido un amplio escenario de análisis que sin embargo no se ha estudiado en profundidad dejando "la perspectiva de género virtualmente ausente" (Meertens, 1994, p.1). Meertens también destaca que el interés investigativo en las mujeres como participantes activas en protestas o movimientos guerrilleros ha llevado al surgimiento de una literatura enfocada en la presencia de mujeres como víctimas de la represión, presentando otras formas de violencia específica contra las mismas: "la tortura como destrucción de la feminidad y la violación como un acto de guerra" (Meertens, 1994, p. 3).

Varias investigaciones afirman que, en los conflictos armados, la mayoría de las sobrevivientes son mujeres (Defensoría del Pueblo, 2008; Casa de la Mujer, 2007; Arango y Zuluaga, 2013) y que cuando deben enfrentarse a la nueva realidad, además de cumplir la labor doméstica, deben convertirse en proveedoras del hogar, papel que se descargaba en la figura masculina. Así, las mujeres deben asumir no sólo tareas concernientes a la producción agrícola sino también los trabajos y roles comunitarios, lo que tiene profundas implicaciones en cuanto a la transformación de las relaciones sociales, económicas y culturales, así como de la vida local en general (Arango y Zuluaga, 2013). En palabras de Harcourt (2010), dichas situaciones se traducen en el aumento de tensiones para compatibilizar y flexibilizar el trabajo reproductivo, productivo y de cuidado.

El análisis de las acciones colectivas de las mujeres, demuestra que en sus signos de identificación colectiva, en términos de Melucci (1996), existe una especie de solidaridad estratégica con objetivos inmediatos. "La organización de estas mujeres obedece a la ampliación del entramado social que defiende posturas pacifistas y que desde sus primeras apariciones en escena reivindica su pertenencia genérica, sin que ello implique una 
adscripción irrestricta al movimiento feminista o a alguna tendencia particular de éste" (Ibarra, 2007, p. 68).

Es importante destacar que las mujeres campesinas han sido doblemente victimizadas en el marco del conflicto. Por un lado, los grupos armados tanto legales como ilegales han utilizado la violencia de género para infundir terror y han cometido violaciones y vejámenes de carácter sexual contra un sinnúmero de mujeres; y por otro, se ha invisibilizado su rol de campesinas y pequeñas productoras. Al respecto, Mondragón (2002) resalta que la negación de derechos como campesinos sugiere una intencionalidad: impedir la presencia política del campesinado en la escena nacional y la vigencia de sus derechos colectivos. "Incluso la Constitución de 1991, que reconoció derechos fundamentales de las comunidades indígenas y afrocolombianas, fue incapaz de identificar los derechos campesinos. Esto fue el reflejo de la situación de persecución a que estaba (y está) sometida la organización campesina" (Mondragón, 2002, p.4). Sin embargo, Nora Segura y Donny Meertens (1997) consideran que la mujer campesina es triplemente víctima:

(..) primero, del trauma que les han producido los hechos violentos (asesinatos de cónyuge u otros familiares, quema de sus casas, violaciones); segundo, de la pérdida de sus bienes de subsistencia (casa, enseres, cultivos, animales), lo que implica la ruptura con los elementos conocidos de su cotidianidad doméstica y con su mundo de relaciones primarias; y tercero, del desarraigo social y emocional que sufren al llegar desde una apartada región campesina a un medio urbano desconocido. Así, la destrucción toca mucho más allá de sus efectos materiales: se trata de una pérdida de identidad como individuos, como ciudadanos y como sujetos políticos, y de una 
ruptura del tejido social a nivel de la familia y de la comunidad, que produce la sensación de estar completamente a la deriva (Segura y Meertens, 1997, p.38).

Muchas de las acciones colectivas de las mujeres colombianas se enmarcan en diferentes esferas, se destacan las movilizaciones por la ampliación de los derechos sexuales y reproductivos, para denunciar las injusticias estructurales y simbólicas, para evidenciar las inequidades de género en el mercado de trabajo, las que exigen la libertad de los secuestrados, denuncian las desapariciones y demandan mayor atención para los desplazados, entre otras (Ibarra, 2007).

Díaz (1999) destaca que como efecto del triunfo de la revolución cubana, en Colombia nace en 1957, la Unión de Mujeres Demócratas, y durante el periodo de enfrentamientos y auge de la Asociación Nacional de Usuarios Campesinos (ANUC)-uno de los sindicatos agrarios con mayor fuerza en Colombia-, la participación de las mujeres fue decisiva y masiva, teniendo un papel preponderante en la toma de tierras, movilizaciones para presionar la liberación de presos, en la defensa de las comunidades en el marco de los desalojos y en los enfrentamientos con la fuerza pública:

La presencia de mujeres en los periodos álgidos de las luchas constituye una de las características de la participación femenina observada tanto en el campo como en la ciudad en diferentes países. Estas acciones de las mujeres en las regiones de mayor conflicto dieron origen a la creación de los primeros "Comités Femeninos", entre 1972 y 1973, desde entonces estos están afiliados a los comités de la ANUC. La dinámica que originó estos comités cumple una función de aglutinamiento de la 
población femenina para defender y apoyar a la comunidad. El mismo hecho de la asociación favorece el surgimiento de relaciones entre las mujeres que en algunos casos conducen a reflexiones de género (Díaz, 1999, p. 117).

Así pues, las investigaciones de Gloria Zuluaga y Carolina Arango (2013), Dora Díaz (1999), Alejandra Miller (2005), María Teresa Matikasevic y Alexander Ruiz (2012) entre otras, retoman el análisis de la relación entre la mujer y el conflicto partiendo de distintas perspectivas y visiones. La idea de una forma de acción colectiva que tiende al reconocimiento no sólo de las sujetas como sujetas con derechos reproductivos y laborales, sino como una sujeta política que se encuentra en una constante lucha por el uso, acceso y tenencia de recursos, ha fundamentado estos escritos. Los casos analizados como la Asociación Nacional de Usuarios Campesinos (ANUC) - Unidad y Reconstrucción (Díaz, 1999), la Asociación de Mujeres Organizadas de Yolombó (AMOY) (Zuluaga y Arango 2013), los relatos de varias mujeres campesinas que sufrieron los embates desde La Violencia (Miller, 2005) demuestran que el rol reproductivo, productivo y comunitario, además del énfasis en la participación en procesos de acción colectiva y de reconocimiento (en tanto son mujeres y son campesinas), son aspectos centrales que guían la labor investigativa de las autoras.

Es necesario resaltar la poca bibliografía resultada de investigaciones que integren a la Federación Nacional Sindical Unitaria Agropecuaria- FENSUAGRO dentro de los marcos de análisis de acción colectiva y de sindicato agrario en Colombia. A pesar de que en algunos escritos es mencionada como parte del movimiento campesino que lucha por una reforma 
agraria y el reconocimiento de derechos políticos para el mismo (Mesías, 2009; Chohan, 2017; Mondragón, 2002), la literatura no ha ahondado en su papel activo y mucho menos en el rol de las mujeres dentro de la organización. En dicho sentido, el caso que se pretende investigar aquí, el papel desempeñado por las mujeres campesinas agrupadas en FENSUAGRO y sus luchas, no ha sido objeto de atención por otras investigaciones hasta el momento.

\section{B. Fundamentación}

La mujer campesina en Colombia ha venido enfrentando múltiples tipos de discriminación, que van desde lo laboral, hasta lo educativo. Es común ver que en la mujer campesina existe un alto nivel de pobreza cuando es ésta a quien le corresponde estar a la cabeza del hogar, que casi siempre es por causa de la violencia, la cual le ha arrancado a su pareja, ya sea reclutándolo o matándolo. El fenómeno del desplazamiento interno por razones de violencia, si bien ha estado presente en la mayor parte de la historia del país, comenzó a sentirse con mayor fuerza a partir del final de la década de los 80 e inicios de los 90. En esos años aumentaron las cifras de asesinatos políticos y masacres, sobre todo en zonas donde confluyeron varios factores: "luchas campesinas en el pasado; enfrentamientos entre guerrilla y ejército luego; compra de tierras por narcotraficantes y llegada de paramilitares a "limpiar" la región de guerrilleros (y también de organizaciones campesinas)" (Merteens, 1994, p. 9). 
Los éxodos más organizados se desarrollaron en el Magdalena Medio ${ }^{9}$ a mediados de los años ochenta, cuando se extendieron los grupos paramilitares, y en el Caquetá ${ }^{10}$ al principio de los años ochenta, con la llegada del M-19 ${ }^{11}$ a la zona. En cambio, las masacres que se perpetraron en la $\operatorname{Costa}^{12}$ en los años 1988-90 dieron lugar a éxodos de muchas familias que buscaron refugio, cada una por su cuenta.

La mayoría de las familias desplazadas fueron encabezadas por mujeres; muchas de ellas viudas y con hijos a cargo, quienes se constituyeron casi en el único motivo para superar su desdicha y emprender una nueva supervivencia en la ciudad: "morir ya no se puede" (Segura y Meertens, 1997, p. 13). Otras mujeres se convirtieron en jefas de hogar en el lugar de exilio, ya que se presenta una tendencia a que las relaciones de pareja se rompan por las tensiones, el miedo, las dificultades de la supervivencia en el nuevo medio, las responsabilidades invertidas, e incluso por la desconfianza y las inculpaciones en los casos en que la mujer desconocía las actividades políticas de su compañero. Y aun cuando no se rompen las relaciones de pareja, muchas mujeres desplazadas terminan siendo las responsables de la supervivencia económica y emocional de la familia, mientras que los hombres se distancian o se refugian en el alcohol (Ramírez, 2005).

La misma necesidad de supervivencia inmediata lleva frecuentemente a la prostitución como único recurso disponible, y en medio de un total desconocimiento sobre (y supresión de) su propia sexualidad. Las mujeres generalmente utilizan canales más

\footnotetext{
${ }^{9}$ Valle interandino formado por el río Magdalena. El Magdalena Medio está repartido entre los departamentos de Antioquia, Bolívar, Cesár, Boyacá, Santander y algunas zonas de los departamentos de Tolima, Cundinamarca y Caldas.

${ }^{10}$ Departamento ubicado en la zona oriental de Colombia, hace parte de la región Orinoquía.

${ }^{11}$ Movimiento 19 de Abril. Organización guerrillera nacida el 19 de abril de 1970.

12 Zona norte de Colombia. La componen los departamentos de Atlántico, Antioquia, Bolívar, Cesár, Córdoba, La Guajira, Magdalena y Sucre.
} 
informales que los hombres y son más recursivas en encontrar mecanismos de supervivencia. Es notorio que las mujeres buscan ante todo solidaridad con mujeres (familiares, comerciantes de la plaza de mercado, maestras), más que con los hombres, frente a los cuales muestran cierto pudor e inhibición. Pero a la vez es importante señalar que nunca buscan solidaridad con otras viudas o desplazadas del mismo lugar (Meertens, 1994).

Para la esposa-madre, la ausencia del marido-padre supone, de modo habitual, redefinir su lugar, duplicar sus funciones y asumir responsabilidades para las cuales no está calificada. Las condiciones económicas de sus hogares, incluso para las asalariadas o que perciben ingresos monetarios, sufren deterioros que van de moderados a totales. La sustitución del marido-padre genera dificultades que varían con la edad, la condición económica y otras características de la mujer, pero también con las de su hogar, en particular el número y edad de sus hijos. Por eso la cristalización más reconocible de la extrema pobreza y de la mayor desprotección es una mujer con una serie de hijos y una cadena de relaciones conyugales fallidas (Segura y Meertens, 1997).

En este contexto general, surgió la necesidad de construir un movimiento agrario y campesino que recobrara identidad de clase, lucha y movilización, por la reforma agraria democrática e integral. Ese fue uno de los primeros objetivos de creación de FENSUAGRO: "la lucha por la tierra, retomando la consigna de la tierra para quien la trabaja. Fue así como impulsamos la recuperación directa de la tierra por los campesinos desposeídos, además de ser coproponentes de varios proyectos de ley de reforma agraria al parlamento colombiano" (Prensa Rural, 2009). Además de la reforma agraria, existían otros objetivos: la construcción de un fuerte movimiento agrario que no sólo luchara por reivindicaciones como el crédito, las vías, la comercialización, la vivienda, educación, salud, el medio ambiente, la defensa de 
los recursos naturales renovables y no renovables, sino que además se plantearon un importante objetivo como la transformación social, la necesidad de construir una nueva sociedad basada en la justicia social al lado de los trabajadores del campo y la ciudad (Prensa Rural, 2009).

A su vez, se crea la Secretaría de la Mujer que se dedica a pensar política de género para la mujer campesina específicamente, ya que ella se encuentra sujeta no sólo a la negación de sus derechos como campesina, sino también a la pérdida de identidad y el desarraigo. Todo ello en un contexto en el que el desplazamiento forzado y la reasignación de las responsabilidades domésticas y productivas agudizan las limitaciones materiales y simbólicas mediante las cuales se prescriben los roles de las mujeres a lo doméstico, y así se obstaculiza su participación en las esferas económica y política.

\footnotetext{
Ahora bien, es por estos eventos que mi interés y trabajo de investigación indaga acerca del papel desempeñado por las mujeres campesinas colombianas lideresas en sus comunidades, agremiadas en la organización sindical agraria denominada Federación Nacional Sindical Unitaria Agropecuaria (FENSUAGRO) y sus luchas en un período de intenso conflicto armado interno (2002-2017). Me interesa indagar acerca de cómo ellas han venido participando de la misma, de qué manera ejercen formas de resistencia pacífica y en qué medida esta agremiación sindical ha participado en dicho proceso.
}

\section{Objetivos e Hipótesis}




\section{Objetivo General}

Analizar el papel desempeñado por las mujeres campesinas, lideresas en sus comunidades, en una organización sindical agraria, en este caso FENSUAGRO en la reivindicación y defensa de sus derechos e intereses como integrantes del campesinado colombiano en un período de intenso conflicto armado interno (2002-2017).

\section{Objetivos Específicos}

A. Describir los procesos sociopolíticos desarrollados en la Colombia rural entre los años 2002 y 2017 haciendo especial hincapié en las políticas emanadas desde el estado, el conflicto armado y la situación de las mujeres campesinas.

B. Identificar y describir las formas e instrumentos gremiales y políticos a través de las cuales FENSUAGRO ha llevado a cabo procesos de reivindicación de derechos de las mujeres campesinas.

C. Identificar y describir las diferentes formas de participación de las mujeres campesinas en FENSUAGRO.

D. Determinar las estrategias de resistencia pacífica que las mujeres campesinas vinculadas a FENSUAGRO han llevado adelante.

Hipótesis: A partir del ingreso de las mujeres campesinas en la Federación (FENSUAGRO), se ha desarrollado una política de género que ha posibilitado el empoderamiento y visibilización de las mismas en defensa de sus derechos y de su territorio. 


\section{Marco teórico, metodología y fuentes de información}

\section{Marco teórico}

La agrupación de campesinos y de mujeres campesinas en torno a luchas como el acceso a la tierra, el reconocimiento de sus derechos como mujeres, pero además como campesinas como derechos políticos, hace necesaria la adopción de tres categorías centrales: acción colectiva, mujer campesina y sindicato agrario.

La acción colectiva puede ser abordada desde distintos autores y desde distintas visiones. Alain Touraine (1987) otorga una perspectiva de la acción colectiva partiendo de la descomposición del sistema social, lo que da paso a los conflictos. Entiende que las conductas colectivas nacen de considerar a los conflictos como respuestas a una "situación que debe valorarse por sí misma, es decir en términos de integración o desintegración de un sistema social, definido por un principio de unidad" (Touraine, 1987, p. 3). Sin embargo, el hecho de hablar de una lucha implica una concepción estratégica, una iniciativa cuya acción está relacionada con la representación de la sociedad como campo de batalla.

Así, un movimiento social no es resultado de una situación social, por el contrario, la situación social constituye el resultado del conflicto entre movimientos sociales que luchan por el control de "los modelos culturales y de la historicidad, conflicto que puede desembocar en una ruptura del sistema político o, por el contrario, en reformas institucionales y que se manifiesta cotidianamente en la forma de organización social y cultural y en las relaciones de autoridad" (Touraine, 1987, p. 3-4). Un movimiento social se convierte entonces en una acción conflictiva mediante la cual se transforman las orientaciones culturales y un campo 
de historicidad en formas de organización social, definidas a la vez por normas culturales generales y por relaciones de dominación social.

Por su parte, Enrique Laraña (1999) entiende a los movimientos sociales como sistemas o redes de individuos y organizaciones, generadores de discursos, cambios de valores y nuevas identidades que los convierte a la vez en productores y producto de modernidad. Esta propuesta está fundamentada en la crítica de una visión tradicional de los movimientos sociales "fundada en una concepción historicista, lineal y objetivista de la acción colectiva y que los consideraba como un agente clave del cambio social a través de los conflictos que suscitaba" (Laraña, 1999, p. 71). Según dicho autor, de la convergencia de distintos enfoques y concepciones constructivistas se pueden explicar los movimientos sociales de distintas maneras:

i) La concepción del movimiento social como un proceso sujeto a continuos cambios y como un objeto de estudio en sí mismo, que no puede explicarse simplemente por las condiciones del contexto en que surge. ii) El énfasis en los procesos de definición colectiva de los problemas que motivan la participación en el movimiento. iii) La capacidad de los que siguen el enfoque clásico para revisar sus supuestos y adaptarlos a la cambiante situación de estas formas de acción colectiva y para eludir la tendencia a calificar a los movimientos de racionales o irracionales en la que se ha centrado la crítica a este enfoque (pp. 81-82) (Adell y Robles, 2000, p. 360). 
De acuerdo a los aportes de Touraine y Laraña, FENSUAGRO se puede considerar como una acción conflictiva que hace parte de una red de organizaciones (movimiento social campesino) y que, a su vez, se configura como generadora de cambios y valores mediante la consideración de la realidad como un escenario de disputa y lucha por ciertos intereses selectivos, que se han mencionado a lo largo de este escrito.

Por lo anteriormente dicho, FENSUAGRO se enmarca como un proceso de acción colectiva convertida en organización social, que inherentemente hace parte del movimiento campesino colombiano, y que a su vez, al contener dentro de su estructura una Secretaría de Mujeres, reafirma su compromiso no sólo con la lucha del campesinado como sujeto político que exige su derecho al uso, tenencia y disfrute de recursos como el agua y la tierra, sino que además establece ante la mujer campesina un rol de doble vía: por un lado la mujer que ha sufrido los embates de la violencia estructurada en el capitalismo y en una jerarquía patriarcal, y por el otro, la campesina y productora que ha vivido el desplazamiento y la negación de los derechos a la tierra y al buen vivir.

Mancur Olson (1985), destaca que uno de los hallazgos frente al estudio de la acción colectiva evidencia que las agrupaciones sindicales obreras, los sindicatos agrarios, las asociaciones profesionales o los grupos de presión, son similares a los servicios del Estado. Sin embargo, a diferencia del Estado, los colectivos proveen de incentivos selectivos que "pueden tratarse, por ejemplo, de una pérdida o de un castigo impuesto únicamente a quienes no ayudan a proporcionar el bien colectivo" (Olson, 1985, p. 206). A su vez, resalta que muchos de los miembros de las organizaciones agrarias norteamericanas forman parte de ellas porque "sus cuotas se deducen automáticamente de los «dividendos de patronato» de las cooperativas rurales, o están incluidas en las primas que pagan a las compañías de seguros vinculadas a sus organizaciones" (Olson, 1985, p. 208). 
Para este caso, los incentivos selectivos de FENSUAGRO podrían enfocarse en la distribución de la propiedad, la defensa de la economía campesina, de la agricultura familiar, la titulación de predios y la destinación de "la tierra para el que la trabaja". Sin embargo, al ser el centro de este estudio las mujeres que hacen parte de este sindicato agrario, es necesario reafirmar el hecho de que las mujeres han sido triplemente victimizadas en el marco del conflicto armado. Han sido víctimas de hechos violentos, han sido mujeres campesinas desposeídas en muchos casos y han sido víctimas del desarraigo y el desplazamiento forzado.

Son precisamente estas razones las que permiten pensar en la acción colectiva de las mujeres campesinas, quienes como lo destacan Díaz (1999), Arizpe (1986) y Suelt-Cock (2015), han encontrado en la organización campesina, una forma de acción colectiva que disputa en diversos escenarios no sólo derechos reproductivos, sino que entiende la necesidad de promover la resistencia frente al conflicto social y político que vive el país, y que precisamente tiene una de sus raíces en la histórica lucha por reformas estructurales que solucionen la inequitativa tenencia de la tierra.

Garretón (2002), afirma que los procesos políticos de lucha y cambio social, como los que han llevado adelante sindicatos agrarios como la ANUC y para nuestro caso FENSUAGRO, son definidos como acciones colectivas con alguna estabilidad en el tiempo y algún nivel de organización, orientados al cambio o conservación de la sociedad o de alguna esfera de ella. Sin embargo, no se puede entender este tipo de acciones colectivas concretas sin comprender que hacen parte de un movimiento social. "La idea de Movimiento Social tiende a oscilar entre dos polos: la respuesta coyuntural a una determinada situación o problema y la encarnación del sentido de la historia y el cambio social" (Garretón, 2002, p. 9) Así FENSUAGRO podría considerarse como parte de un Movimiento Social, pues es un actor concreto que se mueve orientado hacia fines específicos en un nivel histórico- 
estructural de una determinada sociedad y definiendo su conflicto central (inequitativa estructura en la tenencia de la tierra, solución al conflicto social y político, reconocimiento de derechos del campesinado entre otros). Aunque Garretón entiende a las demandas y las movilizaciones como otro tipo de acción colectiva, estas últimas pueden considerarse como parte del accionar político y de lucha del movimiento social campesino, del cual hace parte FENSUAGRO.

\section{Metodología}

Esta investigación se desarrolla mediante un enfoque cualitativo, pues en lugar de iniciar con una teoría particular para luego dirigirse a la realidad, se "comienza examinando el mundo social y en este proceso desarrolla una teoría coherente con lo que observa. Las investigaciones cualitativas se fundamentan más en un proceso inductivo (explorar y describir, y luego generar perspectivas teóricas)" (Sampieri et al., 2006, p. 8). Este enfoque se sustenta en métodos de recolección de datos no estandarizados, además, no se efectúa una medición numérica. La recolección de los datos consiste en obtener las perspectivas y puntos de vista de los participantes (sus emociones, experiencias, significados y otros aspectos subjetivos). También resultan de interés las interacciones entre individuos, grupos y colectividades. El investigador define los datos cualitativos como descripciones detalladas de situaciones, eventos, personas, interacciones, conductas observadas y sus manifestaciones.

Strauss y Corbin (2002), entienden que la investigación cualitativa genera hallazgos que no se producen mediante procedimientos estadísticos u otros medios de cuantificación. "Puede tratarse de investigaciones sobre la vida de la gente, las experiencias vividas, los comportamientos, emociones y sentimientos, así como al funcionamiento organizacional, los 
movimientos sociales, los fenómenos culturales y la interacción entre las naciones" (Strauss y Corbin, 2002, p. 20). Al hablar sobre análisis cualitativo, se hace referencia no a la cuantificación de los datos cualitativos, sino al proceso interpretativo realizado con el propósito de descubrir conceptos y relaciones en los datos brutos y luego organizarlos en un esquema explicativo teórico. De acuerdo con Strauss y Corbin, los componentes principales en la investigación cualitativa son:

i) los datos, que pueden provenir de fuentes diferentes, tales como entrevistas, observaciones, documentos, registros y películas. ii). los procedimientos, que los investigadores pueden usar para interpretar y organizar los datos. Entre estos se encuentran: conceptualizar y reducir los datos, elaborar categorías en términos de sus propiedades y dimensiones, y relacionarlos, por medio de una serie de oraciones proposicionales. Al hecho de conceptualizar, reducir, elaborar y relacionar los datos se lo suele denominar codificar (Strauss y Corbin, 2002, p. 21).

Teniendo en cuenta lo anterior, esta investigación doctoral utilizará la teoría fundamentada. Esta metodología fue construida originalmente por Barney Glaser y Anselm Strauss, quienes se refieren a una teoría derivada de datos recopilados de forma sistemática y analizada por medio de un proceso de investigación:

En este método, la recolección de datos, el análisis y la teoría que surgirá de ellos guardan estrecha relación entre sí. Un investigador no inicia un proyecto con una teoría preconcebida (a menos que su propósito sea elaborar y ampliar una teoría existente). Más bien, comienza con un área de estudio y permite que la teoría emerja 
a partir de los datos. Lo más probable es que la teoría derivada de los datos se parezca más a la "realidad" que la teoría derivada de unir una serie de conceptos basados en experiencias o sólo especulando (cómo piensa uno que las cosas debieran funcionar). Debido a que las teorías fundamentadas se basan en los datos, es más posible que generen conocimientos, aumenten la comprensión y proporcionen una guía significativa para la acción (Strauss y Corbin, 2002, pp. 22-23).

Además de utilizar la teoría fundamentada y de enmarcarse en un enfoque cualitativo, esta investigación es un estudio de caso. Eisenhardt (1989) citado por Martínez (2006), entiende al estudio de caso como "una estrategia de investigación dirigida a comprender las dinámicas presentes en contextos singulares” $(\mathrm{p}, 174)$, que puede combinar métodos para la recolección de información tanto de carácter cualitativo como cuantitativo, con el fin de describir, verificar o generar teoría.

Chetty (1996) identifica al estudio de caso como un método para estudiar un tema determinado desde distintas perspectivas y no desde la influencia de una sola variable, permitiendo explorar de manera mucho más profunda el tema escogido y así obtener un conocimiento más amplio sobre cada fenómeno. Además, el estudio de caso es capaz de satisfacer todos los objetivos de una investigación, e incluso podrían analizarse diferentes casos con distintas intenciones (Sarabia, 1999).

\section{Fuentes de información}

Para dar cuenta de los objetivos planteados, se analizarán leyes y normativas emanadas desde el Estado en el período indicado acerca de los derechos de las mujeres en 
general y de las campesinas en particular. Además, se revisarán fuentes primarias donde se registran intervenciones de FENSUAGRO en la elaboración de dichas leyes a partir de la realización de Congresos a tal fin.

Asimismo, se realizarán entrevistas en profundidad a siete lideresas de la federación: la líder de la secretaría de la Mujer y actual presidenta de FENSUAGRO, dos lideresas comunitarias del norte, una del sur y dos del centro del país y por último dos del oriente del país. Todas ellas son de origen campesino, integrantes de la Federación y militantes de los derechos de las mujeres campesinas. Además, se estudiarán documentos emanados por la Federación con respecto a las mujeres campesinas y su papel en la agremiación. A partir de la realización de observación participante en encuentros, reuniones y actividades de la organización y de la revisión documental de textos producidos no sólo por académicos y académicas sino también por la propia Federación se dará cuenta de los objetivos planteados. Esto lo realizare a lo largo de tres capítulos en los cuales iré desglosando poco a poco lo anteriormente planteado.

Esta tesis contara con un total de tres capítulos que trataran los temas de la siguiente forma: en el primer capítulo se mirara el conflicto, seguridad y movilización popular de la seguridad democrática al proceso de paz de la habana en el periodo comprendido entre (2002-2017). En el segundo capítulo se abordara directamente el tema de la mujer rural, políticas públicas y organización campesina y por último en el tercer capítulo se hará el acercamiento a las mujeres lideresas y campesinas de Fensuagro en una apuesta de resistencia. 


\section{CAPITULO I}

\section{CONFLICTO, SEGURIDAD Y MOVILIZACIÓN POPULAR}

\section{DE LA SEGURIDAD DEMOCRÁTICA AL PROCESO DE PAZ DE LA HABANA (2002-2017)}

La historia de Colombia ha estado marcada por algunos intentos de diálogo con las insurgencias que vieron la luz hacia los años sesenta productos de una intrincada red de causas entre las cuales se destacan la inequitativa estructura de la tenencia de la tierra, la poca o nula apertura democrática, la pobreza y exclusión y el exterminio sistemático de quien se consideraba opositor. Sin lugar a duda, Colombia ha vivido la gran parte de su vida republicana en medio de conflictos armados y civiles que han dejado una cantidad incontable de muertos, desaparecidos y que, por su puesto, se ha incrustado en el imaginario de las distintas generaciones.

Académicos como Daniel Pecáut, Orlando Fals Borda, Eduardo Umaña, Alfredo Molano, Darío Fajardo, Absalón Machado, Jairo Estrada Álvarez, Renán Vega Cantor, Donny Meertens, Mauricio Archila y muchos otros quienes merecen un reconocimiento por su labor investigativa, han analizado, escudriñado y recuperado memorias, narraciones, historias y vivencias de los hombres y mujeres que han sufrido en carne propia la crueldad de la guerra. Aunque no existe una fecha o un periodo aceptado del inicio de la confrontación armada por quienes han dedicado su vida a estudiar la violencia; sus aportes y contribuciones al entendimiento del conflicto resultan, sin lugar a dudas, de gran valor. 
Así pues, este apartado se centra en analizar y describir la forma en que el nuevo milenio trajo consigo renovadas formas de violencia. De igual manera, la autora de esta investigación realiza un esfuerzo por identificar las características sociopolíticas del periodo 2002-2017, teniendo en cuenta la continuación del modelo socioeconómico, pero a su vez las diferencias sustanciales en lo que respecta al abordaje del conflicto armado.

En ese sentido, se inicia con una descripción del Plan Colombia y la política de Seguridad Democrática, se analizan los impactos en términos de violaciones de DD.HH. y el aumento de los desplazamientos masivos. De igual manera, se analiza el impacto del fenómeno paramilitar, la parapolítica y la desmovilización de las Autodefensas Unidas de Colombia (AUC). Luego, se aborda el cambio de gobierno y las perspectivas que éste trajo con un incipiente proceso de paz, para finalizar con los resultados en materia de disminución del conflicto y las nuevas perspectivas.

\section{Plan Colombia y Seguridad Democrática: estrategias del primer gobierno de Álvaro Uribe}

El período comprendido entre 2002 y 2017 en lo que respecta al conflicto armado, puede abordarse desde distintas visiones y entenderse como producto de un acumulado histórico que va desde una lucha fracasada contra el narcotráfico a través del Plan Patriota, pasando por la ruptura de los diálogos del Caguán entre el gobierno de Andrés Pastrana y las FARC-EP, hasta el afianzamiento del aparato paramilitar. Sin embargo, contextualizar y describir el conflicto con punto de partida en el 2002, requiere precisar de la estrategia utilizada por el ganador de las elecciones de ese año: Álvaro Uribe Vélez. 
El Plan Nacional de Desarrollo del 2002-2006 denominado "Hacia un Estado comunitario" inicia en el Capítulo I con la necesidad inmediata de fortalecer las Fuerzas Armadas (en adelante FF. AA.), a través de mecanismos de cooperación internacional con los Estados Unidos y construyendo una intrincada red de informantes civiles. De esta manera, el término Seguridad Democrática fue acuñado por el gobierno nacional, las entidades y órganos territoriales y el discurso de la guerra contra el terrorismo se ubicó en las primeras planas de los periódicos. Se convirtió en una estrategia de la que la gran mayoría hablaba, pero pocos comprendían. Es necesario mencionar que la Seguridad Democrática y el ya mencionado discurso contra el terrorismo fueron aunados por los sucesos del 11-S y la posterior invasión estadounidense a Irak.

Así, la Seguridad Democrática se consolidó como un autoritarismo populista, es decir, una visión autoritaria del poder, no basada en medidas de excepción sino en el estímulo de un respaldo demagógico a esa política. Es el desconocimiento de la distinción entre civiles y combatientes, que le ha permitido al Ejecutivo desarrollar programas como las redes de informantes, basadas en la concepción de que todos, de alguna manera, son combatientes y deben apoyar militarmente a la Fuerza Pública. Eso es autoritarismo populista (El Espectador, 2008).

Sin embargo, Colombia ya había tenido como antecedente de la reducción de libertades civiles y políticas en aras de "preservar la seguridad nacional" al Estatuto de Seguridad Nacional promulgado por el gobierno del presidente Turbay en 1978. A modo de resumen, el objetivo de dicho estatuto era defender las instituciones democráticas, "hoy asediadas por serios peligros, y defender a los asociados de toda clase de asechanzas para lograr una patria donde se viva en paz, sin sobresaltos, con toda clase de seguridades para la 
vida y el trabajo" (El Espectador, 2008). De esta manera, el gobierno de Turbay le concedió a las FF. AA mayores beneficios para fungir como jueces en casos donde la seguridad nacional se viera en riesgo, la Justicia Penal Militar se fortaleció.

Se realizaron un sinnúmero de Consejos Verbales de Guerra en donde acusaron y condenaron a militantes de movimientos sociales y partidos de izquierda por supuestamente simpatizar con las guerrillas que en ese entonces operaban en gran parte del territorio nacional ${ }^{13}$. Estudiantes, profesores y trabajadores sindicalizados tuvieron que comparecer a estos juicios orales, la doctrina del enemigo interno se encontraba en su auge (Ahumada, 2007).

Aunque el Estatuto de Seguridad cimentó las bases para una política pública de seguridad que no tuvo amplia acogida ciudadana, la Seguridad Democrática comprendió la eficacia de influir en el imaginario colectivo a través de la implantación de la necesidad de identificar y neutralizar a los sujetos considerados peligrosos para las instituciones y la vida republicana. Además de esto, la cooperación con Estados Unidos a través del Plan Colombia y el Plan Patriota, significó no sólo la modernización de las FF.AA. en términos de equipos e inteligencia, sino que promovió la intensificación de una guerra que traspasaba las fronteras y que tenía en EE.UU. su mayor promotor.

A pesar de que el Plan Colombia se constituyó a mediados de 1998 en el gobierno de Andrés Pastrana, su aplicación en el gobierno de Uribe resultó determinante. Este plan era una especie de Plan Marshall que incluía apoyo militar, económico y social. Sin embargo, la propuesta del gobierno norteamericano de George W. Bush para el 2002 fue de entregar 360

\footnotetext{
${ }^{13}$ FARC-EP, ELN, EPL, M-19 entre otras.
} 
millones de dólares, de los cuales el 71\% iba destinado a las FF.AA. Un aspecto interesante es que una de las iniciativas del apoyo militar era denominada push into southern Colombia (ofensiva al sur de Colombia) (Vaicius, 2002), que buscaba crear una brigada antinarcóticos con 2.300 hombres en tres batallones nuevos. Esto se debía a que Colombia no era considerada productora de hoja de coca sino epicentro de su transformación y transporte, pues en ese entonces la coca se cultivaba en Perú y Bolivia.

De esta manera, el gobierno de Uribe combinó la estrategia del Plan Colombia para atacar al narcotráfico y la Seguridad Democrática para combatir no sólo a la insurgencia, sino también a todos aquellos que por sus actividades políticas pudieran poner en riesgo la estabilidad del nuevo gobierno. El Plan se había constituido en una especie de proyecto nacional de desarrollo que combinaba la inyección de capital a la represión armada con un variado grupo de programas sociales de corto impacto. De esta manera, el gran músculo financiero del plan se destinaba al combate contra el narcotráfico, y por otro lado los aportes a los aspectos sociales esperaban crear una fuerte base ciudadana que respaldara dicho plan. Así, los críticos quedarían sin el argumento bajo el cual afirmaban que el Plan Colombia no tenía apoyo de la ciudadanía (Estrada, 2002).

El profesor Estrada Álvarez (2002) destaca que el triunfo electoral de Uribe en el 2002 representó la inclinación por buscar una salida militar al conflicto armado y político en el que se encontraba el país. Como se mencionó anteriormente, la amplia aceptación del discurso antiterrorista posterior al 11-S permitió cimentar la idea del Estado colombiano como víctima de grupos terroristas que financiaban sus acciones a través del narcotráfico. De esta manera, se desarrolló un consenso de guerra como política de gobierno fundamentada en la amplia vinculación de grupos civiles, la conformación de las redes de informantes y la 
puesta en marcha de "toda clase de dispositivos corporativistas, que alimentan la concepción miliar de que quien tiene la población, tiene las condiciones para ganar la guerra" (Estrada, 2002, p. 47).

Por ejemplo Nancy Sotomayor en su trabajo denominado Formas de Resistencia Pacífica al Conflicto Armado en la Localidad 20 Sumapaz D.C (2002-2010) afirma que el discurso contra el terrorismo, sumado a la poca confianza que generó el proceso de paz con las FARC y el gobierno de Pastrana, abonaron el camino para debilitar los acercamientos y una salida negociada al conflicto.

[...] De ahí que Álvaro Uribe se presenta como una solución y un cambio. Los colombianos miran que el diálogo con la guerrilla no ha funcionado y ve con agrado la propuesta Uribista (sic) con un carácter autoritario y decidido, que se propone combatir a cualquier precio el terrorismo utilizando los medios que sean necesarios y es de esta manera que formula su campaña a la presidencia con el emblema de la Política de "Seguridad Democrática", con la cual promete devolver la tranquilidad a los colombianos (Sotomayor, 2010, p. 28-29).

Darío Fajardo (2002) resalta que el Plan Colombia se convirtió en una oportunidad para promover variados intereses. De esta manera, se consolidó como una estrategia no sólo de intervención militar estadounidense, sino de una nueva fase de internacionalización del conflicto armado colombiano ${ }^{14}$. Además de las presiones diplomáticas y de la creciente

\footnotetext{
${ }^{14}$ La Misión Yarborough de 1962 se puede considerar como una de las tantas formas de intervención militar en Colombia para combatir ideológicamente y militarmente la consolidación de un proyecto de izquierda en el país. Ver: Molano Bravo (2012), Vega Cantor (2014), Clavijo Mejía (2018).
} 
preocupación norteamericana que para ese entonces posicionaba la guerra contra las drogas como prioridad paralela a la lucha contra el terrorismo, se sumaron sectores petroleros como la Occidental Petroleum

[...] responsable del desplazamiento del pueblo U’Wa en Boyacá y Arauca, en zona aledaña a límites con Venezuela, al oriente del país, empresa interesada en lograr mayor intervención norteamericana, así como las industrias Textron, fabricante de helicóptero Bell Huey y la United Technollogies Inc., productora de los Black Hawk (Fajardo, 2002, p. 79).

La combinación Plan Colombia-Seguridad Democrática resultó seriamente nociva para el ejercicio de derechos políticos y civiles. La lógica del involucramiento civil y de la masiva red de apoyo de un millón de informantes desencadenó una serie de abusos como el desmantelamiento del hábeas corpus, las detenciones arbitrarias durante el desarrollo de operativos contrainsurgentes y el abuso de la detención preventiva.

De acuerdo al informe Tortura en tiempos de seguridad democrática elaborado por la Fundación Comité de Solidaridad con los Presos Políticos en el 2004, durante el período comprendido entre julio del 2002 y junio del 2003, la población recluida en los establecimientos carcelarios aumentó en 7.932 personas, de las cuales el $6.10 \%$ eran sindicadas. A través del decreto 2002 del 2002, y en el marco de la lógica del consenso de guerra, el gobierno justificó que la población civil fuera blanco de la lucha contrainsurgente mediante "la aprehensión preventiva de personas, la interceptación de comunicaciones y 
registro de correspondencia, la inspección o registro del domicilio y la restricción de la libre circulación” (FCSPP, 2004, p. 42).

Así pues, en materia de Derechos Humanos la Seguridad Democrática fue ampliamente cuestionada por sectores alternativos, organizaciones defensoras de los DD. HH, movimientos sociales y partidos políticos de oposición por considerar que el Estado y sus autoridades debían estar al servicio de la comunidad al ser garantes de su seguridad, y no lo contrario. De acuerdo a un artículo publicado por el Movimiento Mundial de los Derechos Humanos en el 2004, la administración de Álvaro Uribe desconoció las recomendaciones de Naciones Unidas y de la Comisión Interamericana de Derechos Humanos al profundizar a través de la política de Seguridad Democrática la crisis de derechos humanos, consolidando un régimen autoritario por medio de diversas estrategias, entre las cuales destacan:

a) Ruptura del principio de distinción, entre población civil y combatientes; b) Involucramiento de civiles en medio del conflicto armado (soldados campesinos, soldados por un día, redes de informantes, proyecto de ley autorizando a civiles para portar armas de guerra); c) Sometimiento de las autoridades civiles al poder militar (Ministerio Público y Fiscales de apoyo o al servicio de la fuerza pública); d) Impunidad, connivencia y favorecimiento de los grupos paramilitares (expedición del decreto 128 de 2003, proyecto de alternatividad penal, ascensos y condecoraciones a personal de la Fuerza Pública, señalado de tener vínculos orgánicos con los grupos paramilitares); e) Ruptura de la autonomía e independencia del poder judicial y el debilitamiento de la misma a través de proyecto de reforma a la justicia; f) Suspensión permanente de los derechos a la libertad, intimidad, libertad de comunicaciones y locomoción (reforma constitucional antiterrorista) (Movimiento Mundial de los Derechos Humanos, 2004). 
Aunque la Seguridad Democrática fue fundamentalmente una política contrainsurgente basada en el fortalecimiento de las FF.AA. para lograr el control del territorio nacional y sus fronteras, la administración Uribe fue una férrea contradictora del discurso que afirmaba que Colombia vivía un conflicto armado interno. De esta manera, los problemas estructurales del conflicto (a saber: pobreza, desigualdad, inequitativa estructura de la tenencia de la tierra, paupérrimos niveles de educación, salud y conexión de las regiones) quedaban relegados al discurso del enfrentamiento a unos grupos terroristas que amenazaban las instituciones y su estabilidad.

Por otra parte, el gobierno comenzó también a darle forma a un esquema intensivo para que los civiles participen de la guerra, desde una red de informantes y civiles armados, que le permiten estar al tanto de los movimientos de los grupos guerrilleros y los nuevos paramilitares llamados "águilas negras" o "bandas criminales" (bacrim), que ponen en peligro su programa neoliberal de desarrollo rural capitalista, confianza inversionista y la inversión extranjera (Matyas Camargo, 2010).

Un aspecto que tuvo amplia repercusión mediática y de indignación nacional fueron los resultados del Decreto 1400 del 25 de mayo de 2006 y la Directiva ministerial 029 del 2005 del Ministerio de la Defensa Nacional. De esta manera, se desarrollaron los criterios para pagos de recompensas por la captura o el abatimiento en combate de miembros de grupos al margen de la ley y bonificaciones por operaciones de importancia nacional. Así, muchos miembros de las FF.AA. cometieron ejecuciones extrajudiciales -mal llamados falsos positivos-. Las víctimas de las ejecuciones extrajudiciales fueron en su mayoría jóvenes en condiciones de pobreza, quienes guiados por promesas de empleo y buena remuneración aceptaron trasladarse de sus ciudades de origen a regiones en Norte de 
Santander, Arauca, Chocó, Antioquia, Huila, Putumayo. De acuerdo a material recopilado en el libro Ejecuciones extrajudiciales en Colombia, 2002-2010. Obediencia a ciegas en campos de batalla ficticios se han documentado más de 10.000 casos de ejecuciones extrajudiciales “y además describe cómo el Ejército de Colombia mató sistemáticamente a civiles para aumentar sus recuentos de cadáveres" (Blu Radio, 2018). De igual manera, muchos soldados que se negaron a cometer dichas ejecuciones extrajudiciales fueron removidos de su cargo.

Ejemplo de lo anterior es un caso recopilado por Revista Semana en el cual se afirma que miembros del comando contraguerrilla Atila 1 con operaciones en La Guajira no asesinaron a dos guerrilleros del ELN por ir desarmados y vestidos de civil:

[...] Lo fácil habría sido dispararles y matarlos, pero estaban desarmados y de civil [...] Aunque no pudimos capturarlos en ese momento era un buen resultado. Estábamos contentos porque la información en los computadores era importante y era el campamento principal que era clave para ellos. Como los dejamos sin armas ni comida como a los tres días terminaron entregándose todos. Pensamos que nos iban a felicitar o algo así. Pero no. Nos metieron al final de una barraca, nos quitaron las armas y nos desnudaron. Cuando entró mi coronel nos empezó a putear y a vaciar y nos dijo que no servíamos para nada, que si no entendíamos que a él de nada le servía la guerrillera viva y que lo que importaba eran las bajas nada más porque él iba a jugar para ascender a coronel y lo medían era por eso. Nos dijo que nos iba a hacer echar a todos (Semana, 2013). 
Uno de los casos más emblemáticos de las ejecuciones extrajudiciales es el de los jóvenes de Soacha. En el año 2008 se comenzaron a reportar gran cantidad de desapariciones en ese municipio de Cundinamarca, en especial jóvenes entre los 17 y 22 años. Cinco de ellos, identificados como Julio César Vargas, Jader Andrés Palacios Bustamante, Víctor Fernando Gómez Romero, Jhonatan Orlando Soto Bermúdez y Diego Alberto Tamayo Garcerá fueron reclutados mediante engaños por los militares para realizar diferentes trabajos en otras zonas del país, los asesinaron y luego fueron reportados como subversivos muertos en combate en Ocaña, Norte de Santander. "Sobre este caso, incluso se conoció que por cada joven reclutado se pagó un millón de pesos” (El Colombiano, 2018).

\section{Desplazamiento forzado: consecuencia de la confrontación y estrategia}

\section{de guerra}

La historia de Colombia se ha caracterizado por complejos y numerosos procesos de desplazamiento a través del despojo, amenazas, intimidaciones y asesinatos, sobre todo en territorios de comunidades indígenas, campesinas y afro. Este fenómeno se ha configurado como una de las herramientas predilectas utilizadas por las élites políticas -y rurales- para profundizar los procesos de acumulación de capital y tierras, así como una característica necesaria para imponer dinámicas de ordenamiento territorial y de desarrollo atadas al poder político.

Lejos de obedecer a un modelo de desarrollo pensado en función de los intereses de la nación colombiana, los movimientos migratorios, la mayoría de ellos involuntarios y violentos, obedecen a las necesidades e intereses de quienes han detentado el poder sobre la 
tierra, el poder político y a los intereses de capitales nacionales y transnacionales (Bello, 2003, p. 1).

Una clara muestra de esta situación son los distintos flujos de desplazados durante y después del período conocido como La Violencia (1946-1958), donde muchos campesinos huyeron hacia los llamados territorios nacionales desde el centro del país para proteger sus vidas de la violencia sociopolítica en la que el país se sumía lentamente. Para los campesinos, la violación de los derechos humanos fue el segundo motivo de protesta en esos años, después de la tierra (Archila, 2018, p. 236).

Así, no sólo se configuraron nuevos escenarios políticos, económicos y culturales en las regiones expulsoras, sino que en las regiones receptoras los procesos de colonización, ampliación de la frontera agrícola y el desarrollo social y comunitario paralelo al controlado desde Bogotá fue tomando forma. De esta manera, un sinnúmero de asociaciones campesinas influenciadas por el lema “tierra pa'l que la trabaja” surgieron en gran parte del país ${ }^{15}$.

Durante la década del ochenta y noventa, el surgimiento de los paramilitares y la aplicación de nuevas formas de guerra no convencional -como la estrategia de tierra arrasada-, así como el fortalecimiento de los carteles del narcotráfico (y su posterior alianza con los paramilitares), significaron nuevos hitos de desplazamiento en una nación convulsionada por la guerra y la paupérrima respuesta del Estado colombiano a las causas estructurales del conflicto.

\footnotetext{
15 Se destacan las Ligas Campesinas en el Sumapaz y el oriente del Tolima de los años 30, la Asociación Nacional de Usuarios Campesinos (ANUC) de los años 70 en el norte del país y FENSUAGRO, con presencia en gran parte del territorio colombiano.
} 
Martha Bello (2003, pág. 1) explica que es en esta época donde se manifiesta con mayor claridad la permanencia histórica de dicho fenómeno, y su utilización en aras de consolidar un modelo de desarrollo excluyente, con características clientelistas, de patronaje, corrupción y violencia. En la década de los noventa se consolida el modelo neoliberal y se acentúan los llamados procesos de modernización del Estado, los cuales implican la redefinición del territorio y sus relaciones de acuerdo con las necesidades de producción y comercialización que el modelo demanda.

Según las cifras construidas por la Consultoría para los Derechos Humanos y el Desplazamiento (CODHES, 2013), el desplazamiento forzado ha sido, desde la década de los noventa, la consecuencia más visible del conflicto. De acuerdo a sus estimaciones, entre 1985 y 2013, más de 5.921.924 personas fueron desplazadas. Lo anterior significa que Colombia, según estimaciones del Internal Displacement Monitoring Centre es el segundo país en el mundo con más desplazados internos, antecedido sólo por Siria. 


\section{Tabla 1. Países con mayores índices de desplazamiento interno}

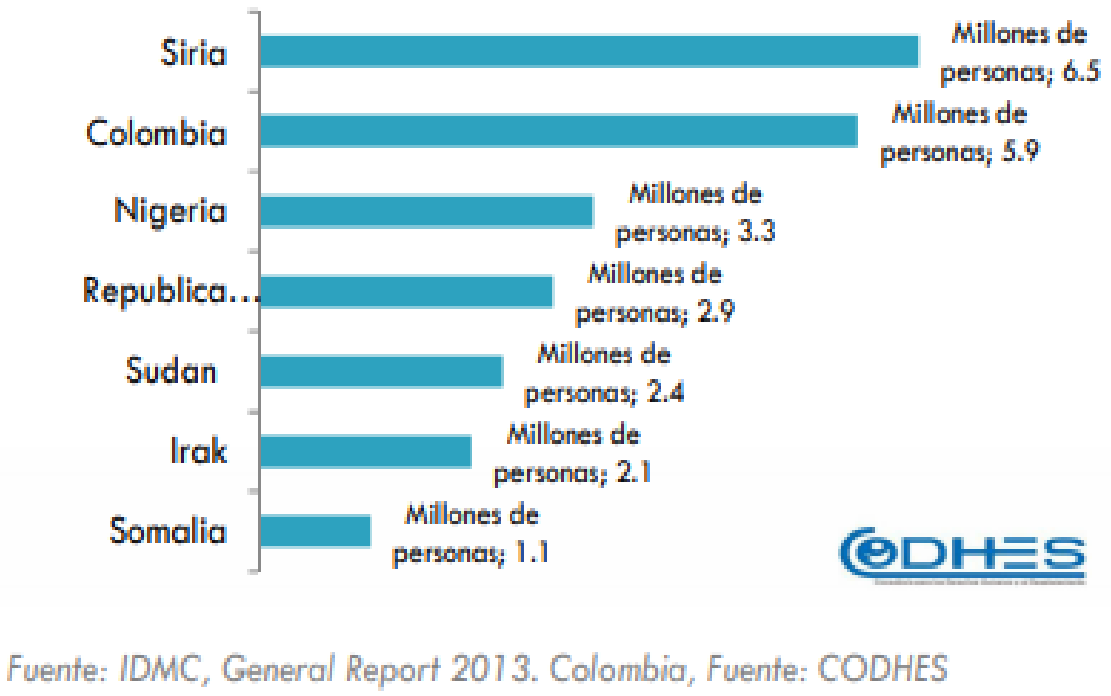

Fuente: CODHES, 2013

Al revisar las cifras de desplazamiento forzado y comparar los territorios expulsores con los territorios donde se concentraron las operaciones de Plan Colombia y Seguridad Democrática, se encuentra una relación directamente proporcional. De acuerdo a datos del Registro Único de Víctimas, 2002 fue el año con mayor número de personas expulsadas, llegando a 776.791. Entre 2002 y 2010, las cifras de desplazados alcanzaron un tope histórico: 4.417.377 desplazados (ver tabla 2). 
Tabla 2: total desplazados 1984-2010

\section{Total Nacional}

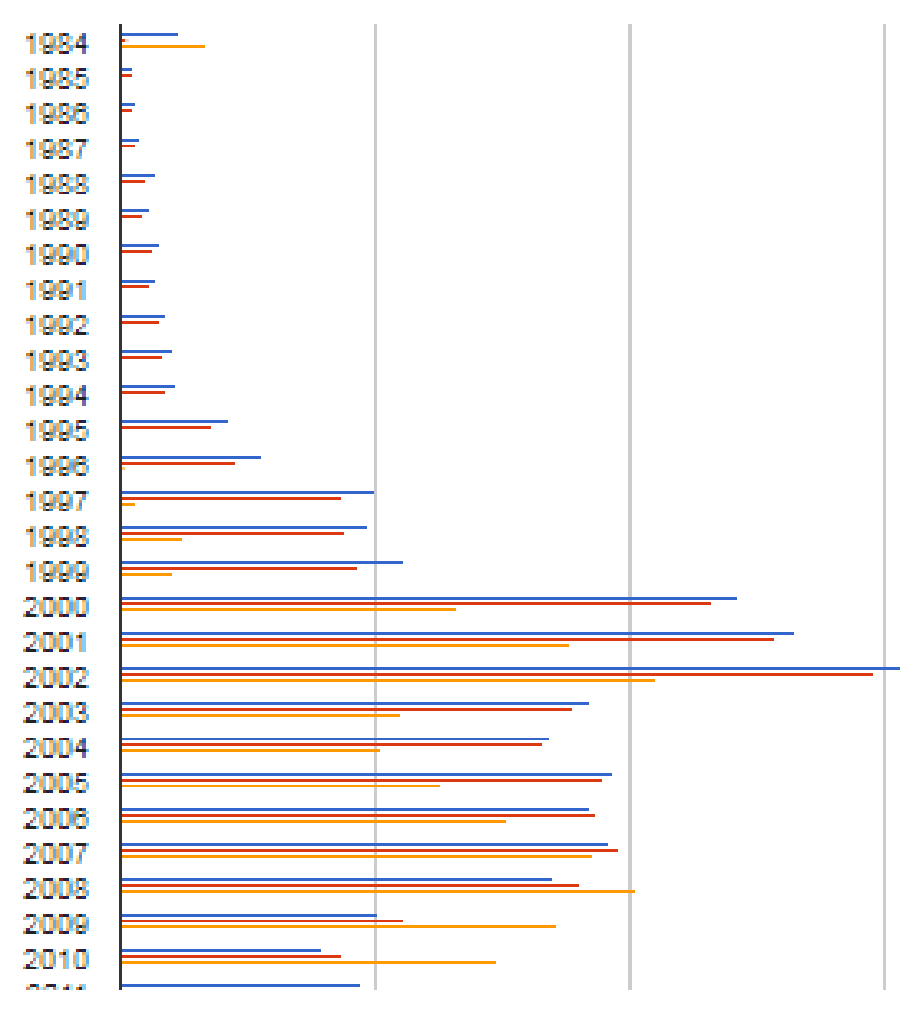

PERSONAS EXPULSA..

PERSONAS RECIBIDAS

PERSONAS DECLARA.

Fuente: Unidad de Víctimas, 2018.

De acuerdo con la Tabla 2, la mayoría de hechos de desplazamiento ocurrieron de manera individual, es decir, núcleos familiares, seguido por los desplazamientos de comunidades enteras. 
Tabla 3: personas desplazadas de manera individual y de forma masiva

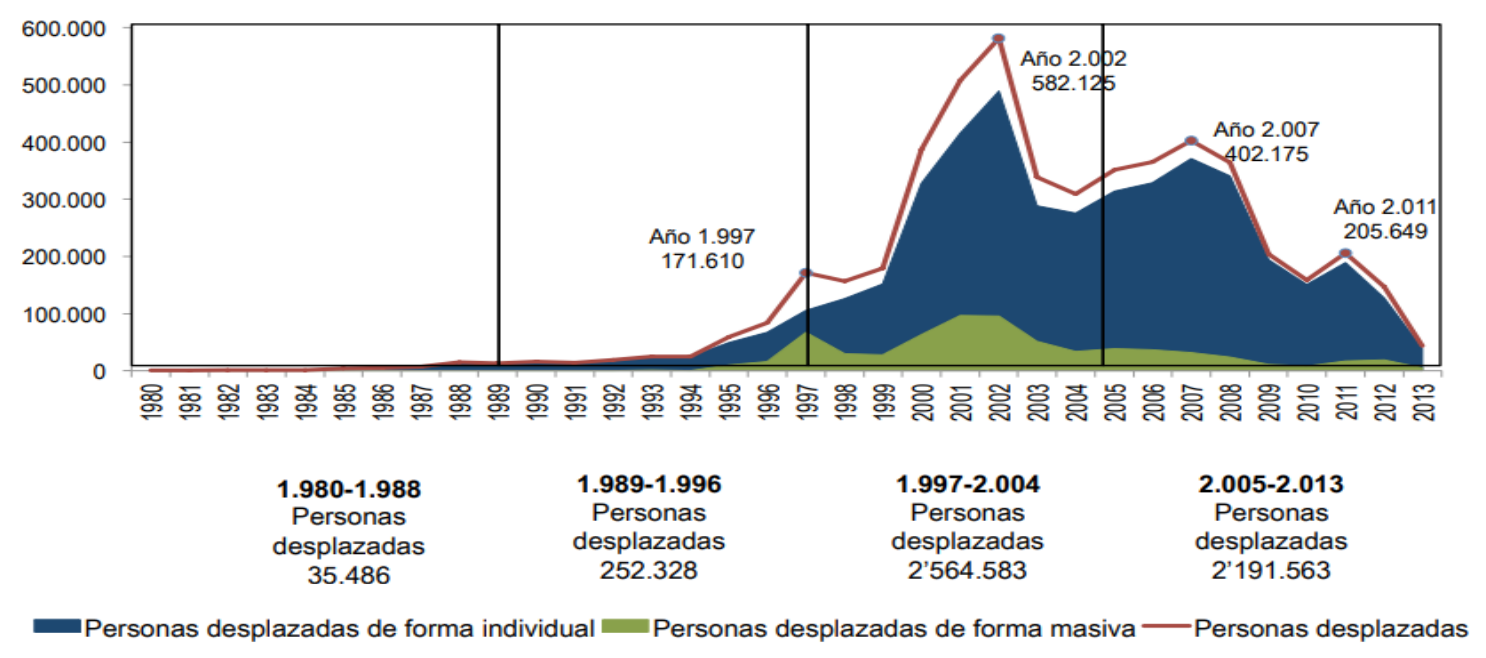

Fuente: Proyecto Desplazamiento Forzado

Fuente: Proyecto Desplazamiento Forzado, 2014.

El mapa número 1 permite identificar las zonas de las cuales provienen la mayor cantidad de desplazados: 


\section{Mapa 1: regiones expulsoras}

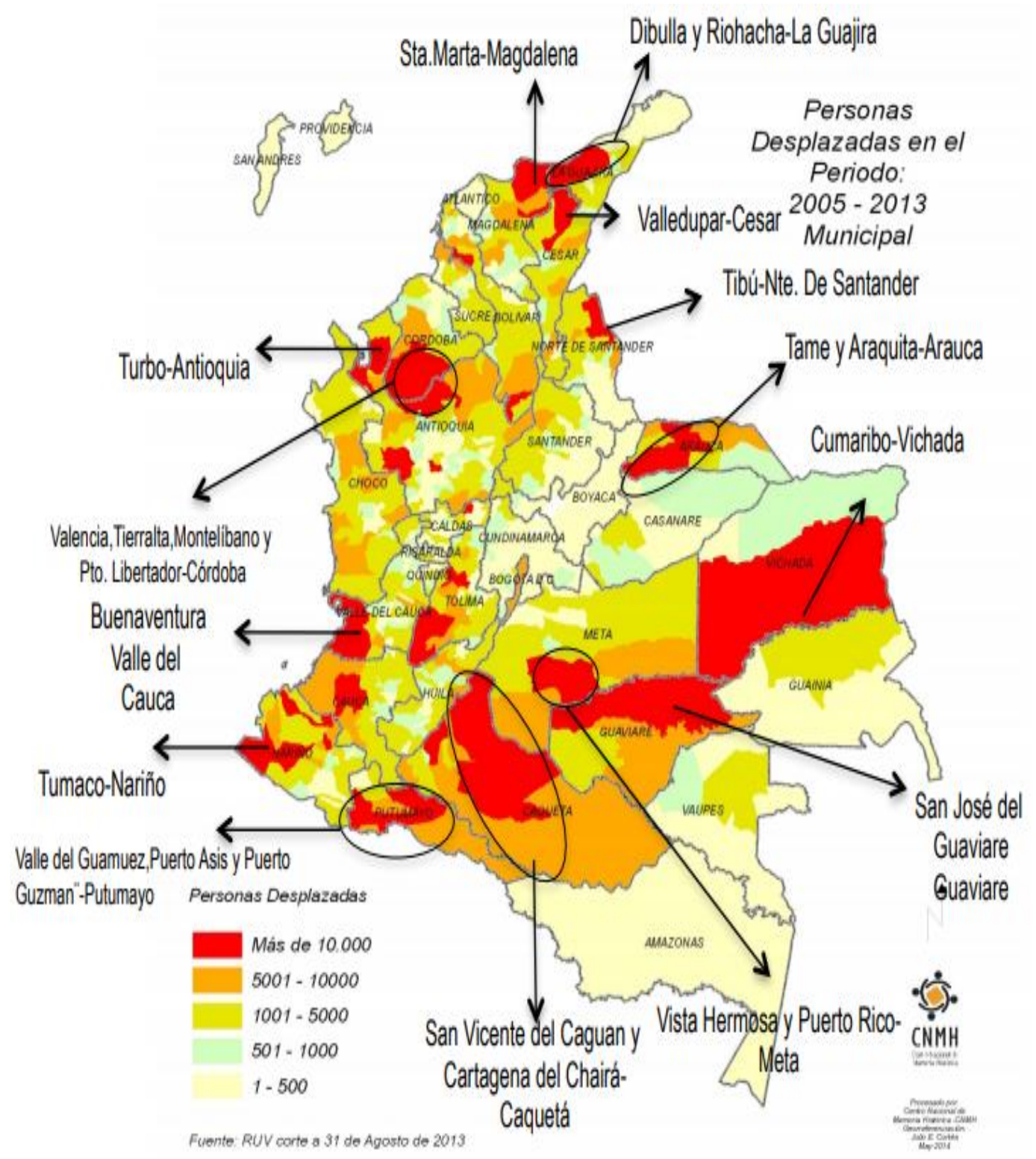

Fuente: Proyecto Desplazamiento Forzado, 2014.

Es importante recordar que la iniciativa dentro del Plan Colombia denominada push into southern Colombia tenía como objetivo "atacar el narcotráfico" en los departamentos de Putumayo, Caquetá, Vichada y Nariño. Como se puede analizar en el Mapa 1, estos 
departamentos priorizados por el Plan Colombia se convirtieron en los mayores expulsores de desplazados. En lo que respecta al Urabá antioqueño, esta región se convirtió en expulsora de comunidades luego de las operaciones de pacificación lideradas por el general Rito Alejo del Río y ordenadas por el entonces gobernador Álvaro Uribe Vélez (1995-1997).

Tiempo después, el general retirado Rito Alejo del Río, quien fue comandante de la Brigada XVII, fue condenado a 25 años de prisión por el asesinato de Marino López Mena, ocurrido el 27 de febrero de 1997 en Bijao (Chocó). Según la justicia, el campesino fue torturado y descuartizado por los paramilitares cuando Rito Alejo estaba a pocos kilómetros. Esto ocurrió en plena operación Cacarica de los paramilitares, diseñada para exterminar a la guerrilla, al tiempo que la Brigada XVII desplegaba la operación Génesis que tenía el mismo propósito. Alias “el alemán” en su momento dijo que él mismo se reunión con Rito Alejo del Río, junto con otros jefes de las autodefensas, para diseñar la operación Cacarica (Verdad Abierta, 2015, pág.34).

El año 2002 fue sin lugar a duda, el inicio de un período complejo en el tema del desplazamiento forzado en Colombia. En esos 12 meses, marcados por el fin del proceso de paz con las FARC y la transición de la administración Pastrana a la de Álvaro Uribe, “el 85 por ciento de los municipios del país vio huir a algún porcentaje de sus pobladores por motivos relacionados con el conflicto armado" (El Tiempo, 2003). Aunque el desplazamiento puede considerarse como un efecto colateral del conflicto armado, organizaciones como CODHES destacaron a principios del año 2003 que se había convertido en una estrategia de guerra asociada a intereses económicos. No solo hay desplazamiento porque hay guerra, sino que hay más guerra para desplazar más gente porque los intereses económicos -que van más allá de la tenencia de la tierra- así lo determinan y porque el conflicto armado es un 
escenario favorable para afirmar este tipo de relaciones de poder (CODHES, 2003, en: El Tiempo, 2003).

Ahora bien, retomando la idea del desplazamiento como herramienta utilizada para acumular capital e influir en las dinámicas socio territoriales, si se compara el mapa de regiones expulsoras con el mapa de zonas con gran importancia minera, petrolera y para la agroindustria, se puede evidenciar que empresas y terceros se beneficiaron el conflicto. Tal es el caso de las plantaciones de palma aceitera en el Urabá, Córdoba y Bolívar, los llanos orientales y algunas regiones de Norte de Santander y el Magdalena Medio, donde los paramilitares desplazaron comunidades enteras para permitir el acaparamiento de tierras.

Camilo Rey Sabogal (2013), realiza un certero análisis espacial de la correlación entre cultivo de palma de aceite y desplazamiento forzado en Colombia, llegando a la siguiente conclusión:

[...] Los resultados de econometría evidencian una correlación positiva entre desplazamiento forzado y la expansión de la palma de aceite que ocurrió en los nuevos municipios palmeros y zonas de mayor expansión del cultivo. Además, los resultados mostraron que la relación entre las variables se hace más fuerte en el Chocó, Catatumbo, Antioquia y en el norte del departamento de Bolívar (Rey Sabogal, 2013, p. 716). 
Mapa 2. Zonas sembradas con palma de aceite (2009)

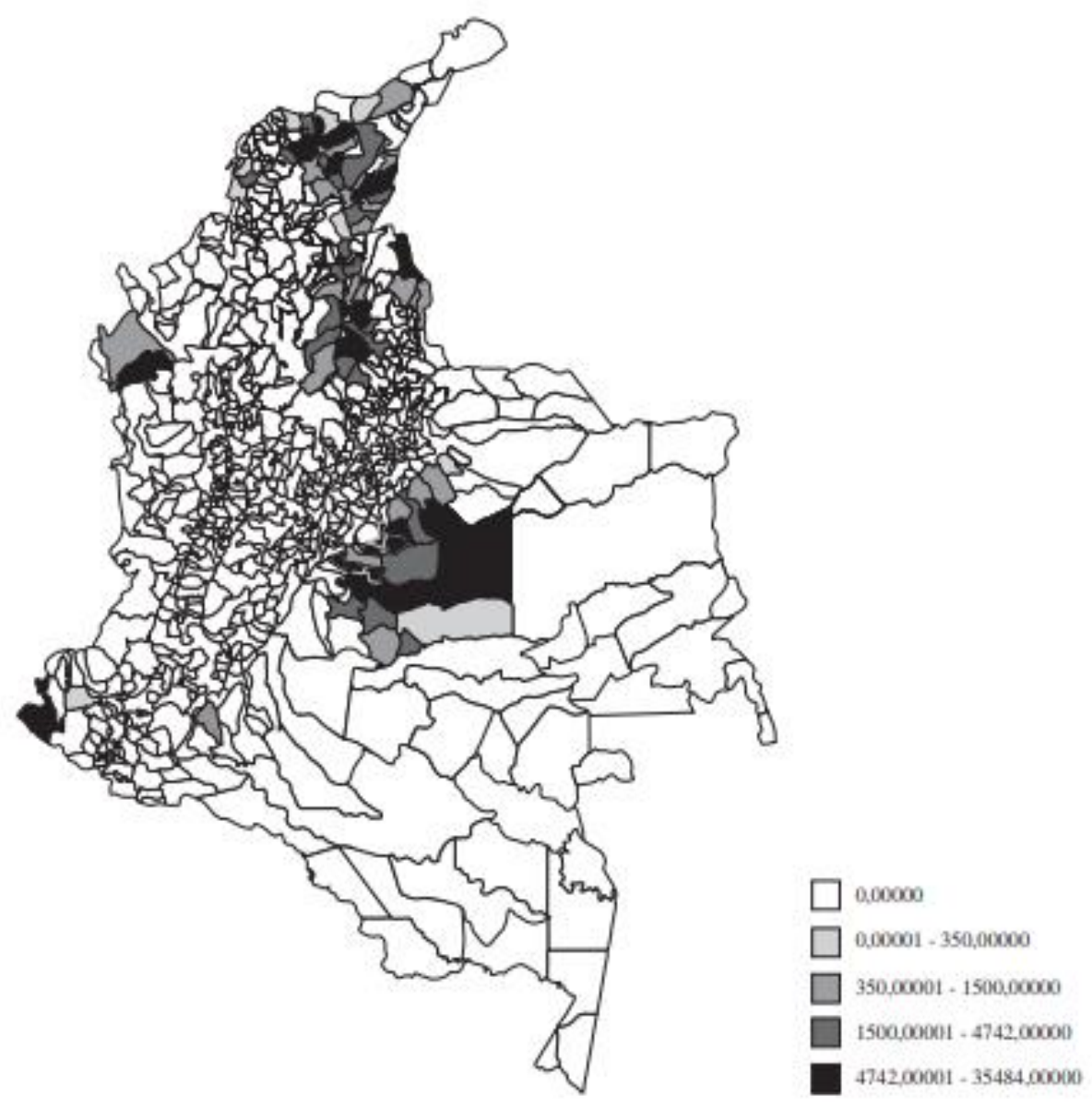

Fuente: Camilo Rey Sabogal. 2013

Mapa 3. Desplazamientos realizados por paramilitares entre 1997 y 2009 


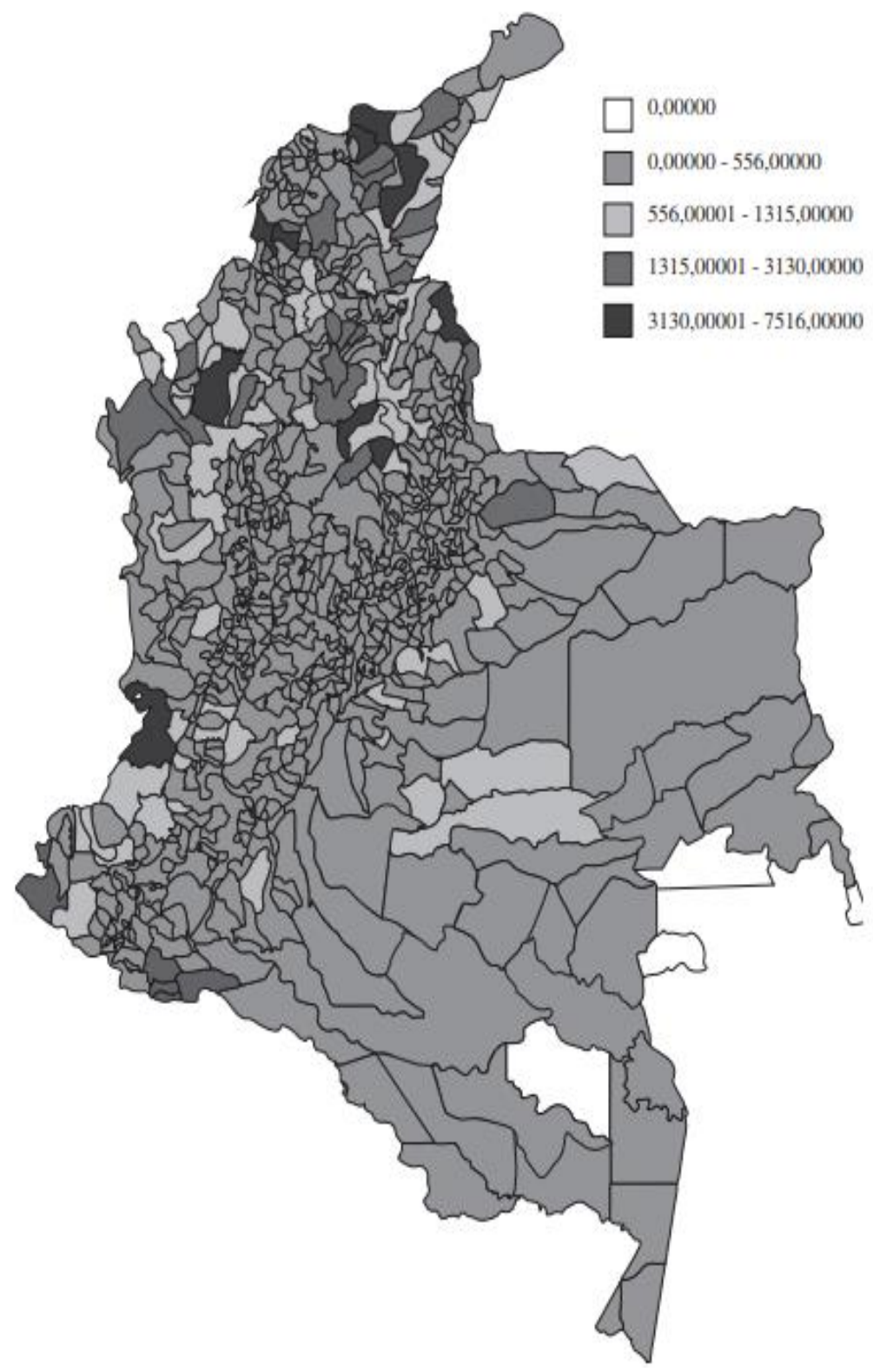

Fuente: Camilo Rey Sabogal. 2013.

Clavijo, Giraldo y Ballén (2019) en su documento titulado Aproximación al problema de la tenencia de la tierra en Colombia: de la negociación en la mesa de La Habana al Medio sostienen que 
Los paramilitares compran las tierras a muy bajo costo mediante las amenazas de muerte, lo que produce desplazamientos; luego las empresas compran esta tierra y siembran palma para engordar la tierra, pueden pasar 15 años sin que esa tierra la toquen, y cuando se necesita para un megaproyecto, la tierra cuesta 20 veces de lo que le costó a la empresa palmera, y además les deben pagar un porcentaje por cada palma que tienen sembrada (Lozano, 2016 en: Clavijo, Giraldo y Ballén, 2019).

De la alianza paramilitares-palma la estrategia utilizada fue el desplazamiento para copar territorios y acumular tierras. Se destaca el caso de la región del Urabá, comprendida entre los departamentos de Antioquia y Chocó, en el noroccidente de Colombia. En esta zona, las empresas Urapalma, Palmas del Curvaradó, Selva Húmeda, Palmura, Inversiones Fregny Ochoa, Palmas de Bajirá, Palmadó, Palmas S.A. y Agropalma se constituyeron como fachada para tratar de legalizar el despojo de tierras de miles de familias en Curvaradó y Jiguamiandó. De acuerdo con un documento de la Unidad de Derechos Humanos de la Fiscalía se pudo constatar que en esas empresas fachada:

[...] trazaron múltiples estrategias jurídicas para legalizar la adquisición y posesión de tierras, a lo cual combinaron una febril ofensiva paramilitar que resultó muy útil a la hora de contrarrestar la reticencia de los vendedores, así como la enjundia de los opositores a la expansión de los cultivos de palma (El Tiempo, 2010).

En la zona del Catatumbo, en el nororiente colombiano, la situación no fue tan disímil. Según el escritor y sociólogo Alfredo Molano (2012), la mayoría de los cultivadores de palma 
adquirieron tierras y títulos del año 2000 en adelante. La avanzada paramilitar activó el mercado de tierras con énfasis en la oferta de propiedades a bajos precios, y en otros casos a raíz de la venta coactiva. Así, los precios de la tierra antes de la Ley de Justicia y Paz se desplomaron y el precio de la hectárea llegó a 50.000 pesos. "Los campesinos abandonaban la tierra o vendían muy barato. Las masacres sembraron el terror y en ese río revuelto se hicieron infinidad de transacciones y se creó un verdadero caos jurídico” (Molano, 2012).

En el Chocó, el proyecto palmero se inició en 1997 con la Operación Cacarica de los paramilitares (apoyada por la Operación Génesis liderada por el general Rito Alejo del Río) durante de la gobernación de Álvaro Uribe Vélez (1995-1997). Con la avanzada paramilitar y el apoyo institucional militar, el despojo se fue consolidando y "quienes estaban al frente del proyecto palmicultor se valieron nuevamente de procesos de desplazamiento forzado en los años 2000 y 2002, propiciados nuevamente por grupos paramilitares, esta vez de las AUC, para adelantar una segunda fase de intervención económica” (Verdad Abierta, 2011).

\section{Diálogos con los paramilitares y desmovilización: se renueva el ciclo de}

\section{violencia}

En noviembre del 2002, el recién posesionado presidente Álvaro Uribe realizó un llamado a las (AUC). Los paramilitares liderados por Carlos Castaño respondieron a la invitación decretando una tregua el 1 de diciembre de 2002. "La Ley 782 de 2002, el decreto 1258 de 2003 y la Ley 975 de 2005, llamada Ley de Justicia y Paz, reglamentaron la desmovilización de los paramilitares" (El Tiempo, 2010), de esta manera, se reglamentó la obligación de los combatientes para contar a los jueces y fiscales de los tribunales sus 
implicaciones en hechos delictivos para poder acceder al beneficio de pena máxima de ocho años en establecimiento carcelario.

A inicios del 2003, representantes del gobierno Uribe y el Consejo Mayor de las AUC se reunieron en Santa Fe de Ralito (Córdoba) y el 15 de julio de ese año se firmó el "Pacto de Ralito", en el cual los paramilitares se comprometían a desmovilizar todos sus miembros antes del 2005. De acuerdo con grabaciones de las versiones libres de los paramilitares Salvatore Mancuso y Ernesto Báez, Mancuso convocó a un número considerable de políticos de la Costa en la finca de Salomón Feris Chadid, alias 08. Mancuso asegura que durante la reunión “sí leyó el 'Pacto' que dejaba constancia de la alianza entre dirigentes regionales y jefes paramilitares para consolidar un movimiento político a escala nacional" (Verdad Abierta, 2010).

Mientras los invitados iban llegando a la finca, Salvatore Mancuso y los otros jefes paramilitares se reunían a pocos kilómetros de distancia en la finca 'La 06’, en compañía de Jesús María López, gobernador de Córdoba, y su sobrino, el exsenador, Juan Manuel López Cabrales. El político intentaba que Mancuso le perdonara la vida, ya que él lo había declarado objetivo militar. Según el paramilitar López se salvó por la intervención de su tío, el entonces gobernador Jesús María López. Pero también porque el gobierno amenazó a Mancuso con extraditarlo si le llegaba a pasar algo al entonces senador (Verdad Abierta, 2010).

Entre los firmantes del Pacto de Ralito estaban Salvador Arana (ex gobernador de Sucre, condenado a 40 años de cárcel), Jesús María López (ex gobernador de Córdoba con proceso pendiente), Alfonso Campo Escobar (ex representante por Magdalena condenado a 6 años de prisión), William Montes (ex senador de Bolívar con proceso archivado), Juan Manuel López Cabrales (ex senador condenado a 74 meses de prisión), Luís Carlos 
Ordosgoistia (ex representante a la Cámara por Córdoba, absuelto) y Miguel de la Espriella (ex representante a la Cámara por Córdoba condenado a 45 meses de prisión), entre otros. Aunque el documento salió a la luz sólo hasta 2007, los nexos de políticos con paramilitares eran reconocidos en amplias zonas del país. De esta manera, se evidenció la forma en que el proyecto paramilitar encontró en la política tradicional un aliado incondicional.

Aunque los paramilitares decretaron una tregua en el 2002, con el fin de generar confianza entre las partes que iniciaban los diálogos de paz, un informe del Centro Nacional de Memoria Histórica destaca que los paramilitares perpetraron nueve masacres de no menos de diez víctimas. La Masacre de Tomar razón, en La Guajira, perpetrada en el 2002; la Masacre de El Afilador en Puerto Asís, Putumayo, perpetrada en 2004; la Masacre de Punta del Este, perpetrada en el 2005; la Masacre de San Juan de Arama, perpetrada en 2006; la Masacre de Arauca, en 2004; son sólo algunos de los hechos cuyas magnitudes ocuparon la atención de la opinión pública. Aunque fueron una clara violación a la tregua decretada, los diálogos transcurrieron con normalidad y se ocultaron responsabilidades.

\section{Tabla 4: masacres cometidas durante los diálogos de paz con los paramilitares (1980-2012)}




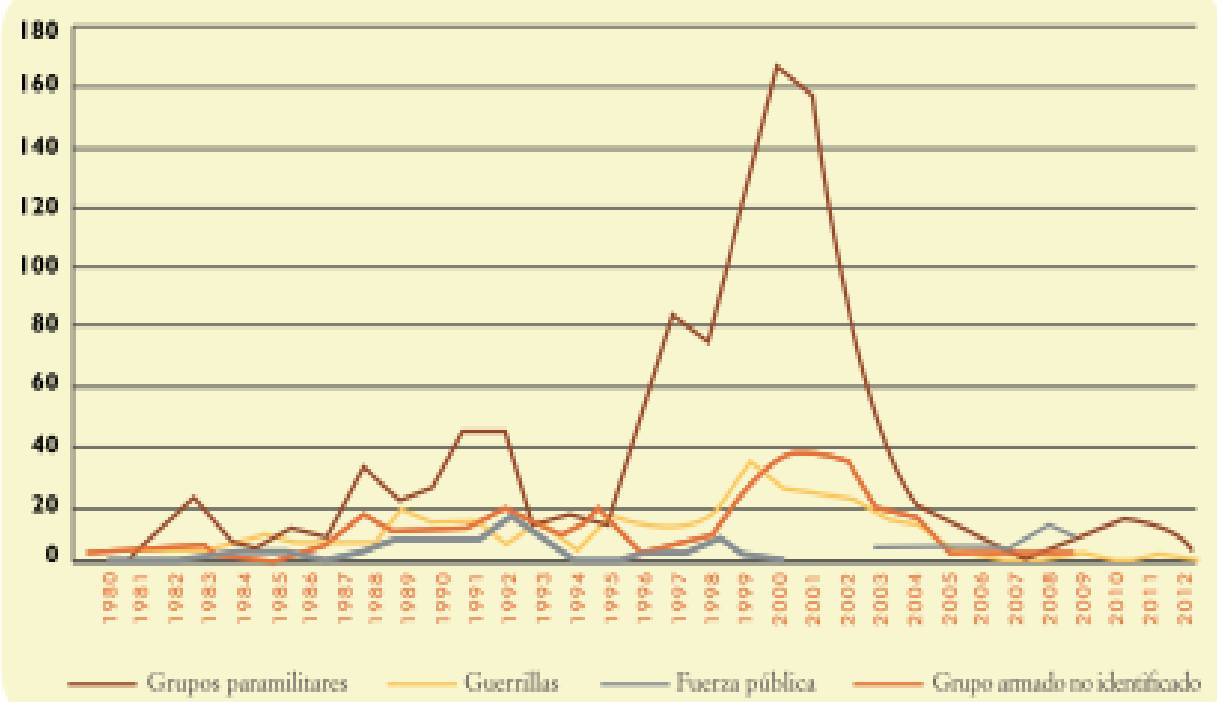

Figura 3. Evolución de casos de masacre por conflicto armado en Colombia según presunto responsable, 1980-2012. Fuente: GMH, base de datos de masacre del conflicto armado en Colombia (1980-2012).

Fuente: Centro de Memoria Histórica. 2013.

Como se evidencia en la tabla 4, entre 1998 y 2001 las masacres paramilitares tuvieron su auge con más de 160 hechos documentados. Sin embargo, aunque el contexto del 2002 y 2006 supuestamente era de cese de acciones armadas. Sin embargo nos muestra que los paramilitares cometieron entre 100 y 110 masacres. Esto es una clara violación a la tregua, al derecho internacional humanitario y a las reglas de juego del proceso de paz. Sin embargo, esto poco o nada impactó en la sociedad y en la opinión pública, a pesar de que muchos de estos hechos salieron a la luz pública.

Ahora bien, las desmovilizaciones de las AUC iniciaron el 25 de noviembre de 2003 en Medellín, donde tuvo lugar la entrega de armas del Bloque Cacique Nutibara y culminaron el 15 de agosto de 2006 con la entrega de armas del Bloque Élmer Cárdenas. En 38 actos 
públicos, se desmovilizaron 31.671 paramilitares. "Las organizaciones con mayor número de desmovilizados fueron el bloque Central Bolívar con 6.348, el bloque Norte con 4.760, el bloque Mineros con 2.780, el bloque Héroes de Granada con 2.033 y el bloque Elmer Cárdenas con 1.538” (Verdad Abierta, 2008).

Inicialmente, los paramilitares se concentraron en zonas pre-establecidas, teniendo como compromiso previo la custodia de dichas áreas por parte de las FF.AA. y el gobierno. De acuerdo al documento de acuerdo del cese al fuego y del proceso de desmovilización, "la concentración de sus integrantes incluirá todos los rangos de mando, disponiendo de las garantías que para tal efecto se convengan entre las partes" (Semana, 2003).

Aunque dicho acuerdo señalaba el compromiso de las AUC de mantener el cese de hostilidades, como se evidencia en la tabla 4, dicho compromiso no fue cumplido. De hecho, en el documento firmado por Carlos Castaño, Salvatore Mancuso, Adolfo Paz, Vicente Castaño, 'Hernán Hernández', Luis Cifuentes, Ramiro Vanoy, Francisco Tabares y 'Jorge Pirata' -representantes de los paramilitares- y Luis Carlos Restrepo, Carlos Franco, Jorge Ignacio Castaño, Eduardo Espinosa, Gilberto Alzate Ronga, Ricardo Avellaneda y Juan B. Pérez -negociadores del gobierno-, las AUC señalan su voluntad de perfeccionar mecanismos para evitar el incumplimiento de los acuerdos.

De acuerdo a conversaciones reveladas por WikiLeaks y retomadas por el Centro Nacional de Memoria Histórica (CNMH) consignadas en el informe "Desmovilización y reintegración paramilitar" (2015) de los 30.000 combatientes que se desmovilizaron, al parecer sólo 15.000 pertenecían realmente a las estructuras armadas de los paramilitares: 
Ya entonces quedaba en evidencia que al parecer sólo 15.000 de los 30.000 desmovilizados fueran realmente del ala armada de las AUC (...) El cable informó que, según analistas, alrededor de 4.000 -armas- no fueron entregadas (...) se hace referencias a desavenencias entre el entonces ministro del Interior, Sabas Pretelt, con el Alto Comisionado para la Paz, Luis Carlos Restrepo, con respecto a las desmovilizaciones. (...) el ministro Sabas Pretelt culpaba al comisionado Restrepo de haber metido a 12.000 paramilitares más de los que el Gobierno estimaba; y a su vez Restrepo responsabilizaba a Pretelt de estar haciendo promesas a los paramilitares que el Gobierno no podía cumplir (CNMH, 2015, pp. 72-73).

Las inconsistencias en las cifras se sumaron a la aparición de nuevos grupos armados de manera simultánea a la desmovilización de algunos bloques paramilitares. María Teresa Ronderos en su investigación periodística "Guerras recicladas" (2014) resalta la forma en que el surgimiento de los nuevos grupos armados denominados en muchas ocasiones "bandas criminales" es en realidad la consecuencia de la capacidad cíclica que tiene la guerra. En ese sentido, muchos de los nuevos grupos al margen de la ley son compuestos por paramilitares que no se desmovilizaron o que acudieron a los beneficios económicos del proceso de reintegración y que luego se reorganizaron.

Académicos como Carlos Medina Gallego, en el año 2015, destaca, que no existe una diferencia sustancial entre neo-paramilitares y bandas criminales, pues "los primeros están mucho más coordinados con el control territorial en torno al discurso antisubversivo, y los segundos al desarrollo de una administración criminal del mismo, complementaria de la economía ilegal del narcotráfico y la explotación de recursos mineros y agropecuarios" 
(citado en Verdad Abierta,com 2015). Por su parte, Raúl Zelik afirma que "en Colombia, el paramilitarismo todavía no es historia. Decenas de grupos "disidentes", "rearmados" o “emergentes" hacen que exista una continuidad del poder paramilitar" (citado en Verdad Abierta. com2015).

Por su parte, Ariel Ávila investigador de la Fundación Paz y Reconciliación, considera que luego de la desmovilización paramilitar en Colombia, surgieron tres nuevos grupos: 1. Los disidentes, es decir, estructuras que nunca se desmovilizaron. 2. Los rearmados, es decir, estructuras que entraron al proceso de Ralito, se desmovilizaron y luego de un tiempo se rearmaron. 3. Grupos emergentes, es decir, surgieron grupos que indirectamente se vinculaban a los grupos paramilitares, pero que tenían una génesis nueva (Semana, 2016).

De acuerdo con Ávila, entre el 2006 y 2011 emerge la primera generación de los nuevos grupos armados, de hecho, llegaron a existir 36 de estas estructuras. Luego del 2011 y como efecto de un proceso de unificación entre estructuras criminales, se comienzan a consolidar redes que distan de la organización jerárquica de los 36 grupos preexistentes. En efecto, afirma Ávila, dichos grupos neo-paramilitares se organizaron en nodos de operatividad a nivel nacional. "Es en este sentido cuando podemos afirmar que uno de los modelos de operación consiste en la descentralización de la estructura criminal" (Semana, 2016).

Según investigaciones de la Fundación Paz y Reconciliación (2016), en la actualidad cerca del 30\% de las Bandas Criminales, BACRIM son estructuras jerárquicas que protegen testaferros y se lucran de la extorsión, minería ilegal, contrabando, tráfico de armas y el control de las rutas del narcotráfico. "Estas estructuras mantienen vínculos con sectores 
políticos y judiciales, y financian campañas. Es decir que no sólo les importa el negocio criminal" (Fundación PARES, 2016). En este grupo se destacan las Autodefensas Gaitanistas y los Urabeños, quienes tienen en su estructura jefes militares y políticos, encargados de dirigir las operaciones y sus relaciones con otros grupos armados y con sectores políticos y económicos. "Muestra de ello es que Otoniel, jefe de los Urabeños, reconoció que 7 alcaldes del Urabá eran fichas de él” (Fundación PARES, 2016).

Otro 30\% de las BACRIM es de alcance regional. Mantienen una fuerte relación con el lucro del sicariato y la intimidación a defensores de DD.HH. La Fundación las considera estructuras que venden el servicio de seguridad privada al mejor postor, cuyos mandos militares tienen amplio poder a nivel local y regional. Luego encontramos otro $30 \%$ de BACRIM que son de alcance regional. "Por ejemplo, en este grupo encontramos bandas como las disidencias del ERPAC (Ejército Revolucionario Popular Antisubversivo de Colombia): el Bloque Meta y los libertadores del Vichada, en el oriente colombiano" (Fundación PARES, 2016). El 40\% restante, son pequeños grupos organizados cuyo alcance es local y se confunden con pandillas y grupos delincuenciales que trabajan para los dos primeros grupos.

\section{Pactos y parapolítica: estrategia para "refundar la patria"}

Luego de la desmovilización de las estructuras paramilitares, en el 2006 se conocieron de manera pública detalles que revelaban la alianza entre grupos políticos y dichas estructuras armadas en la Costa Atlántica. Aunque se trataba de un tema que en las regiones era 
ampliamente conocido, la coerción y las amenazas a quienes denunciaban dichas uniones, así como la cooptación de los entes de control y vigilancia por parte de aliados de los paramilitares, minimizaron las consecuencias en términos jurídicos.

El primer hecho concreto que impulsó las investigaciones contra congresistas aliados a los paramilitares, fue la denuncia presentada por Clara López Obregón, quien solicitó a la Corte Suprema de Justicia investigar a los congresistas para establecer si la afirmación del jefe paramilitar Salvatore Mancuso era cierta. Mancuso afirmó años antes que el 35\% del congreso estaba controlado por las AUC.

Semana reveló con detalles cómo fue que los tentáculos del comandante del Bloque Norte de las Autodefensas, Rodrigo Tovar Pupo, 'Jorge 40', hoy desmovilizado, penetraron el Departamento Administrativo de Seguridad (DAS), y de qué manera se fraguó el fraude electoral de 2002 y 2006. Dichas investigaciones, que en principio fueron desmentidas por el presidente Álvaro Uribe, resultaron probadas poco a poco por la justicia. El Tiempo, Cambio y algunas investigaciones de Claudia López (también publicadas por Semana.com) pusieron el dedo en la llaga sobre la forma como los paramilitares se repartieron los votos de la Costa atlántica para lograr que sus amigos llegaran al Congreso (Semana, 2007).

Sumado a Clara López, el hoy senador de la república Gustavo Petro realizó un debate de control político en el que demostró la forma en que las estructuras paramilitares se habían aliado con políticos en los departamentos de Sucre, Córdoba, Cesar y Magdalena, así como en organismos como la Fiscalía. Por su parte, la exsenadora Piedad Córdoba adelantó más de cinco debates de control político en los que demostró la alianza entre el DAS y bloques de las autodefensas. 
Además de los debates de control político, las autoridades decomisaron un computador al paramilitar Édgar Ignacio Fierro, alias Don Antonio, que contenía información privilegiada sobre los contactos de Jorge 40, comandante del Bloque Norte de las AUC. Aunque cinco congresistas que hacían parte de los contactos de Jorge 40 fueron eliminados de las listas de candidatos para las elecciones legislativas del 2006 por orden presidencial, se reencaucharon en otros partidos, también uribistas (denominado al grupo político cuyo líder es Álvaro Uribe Vélez)

[...] un paramilitar desertor conocido como alias 'Pitirry' (hoy asilado en Canadá) dio detalles sobre las masacres cometidas en Sucre; algunos senadores, llevados por el desespero, reconocieron sus contactos con las autodefensas; y luego Salvatore Mancuso divulgó un documento que compromete a 28 líderes de la Costa en un pacto con las autodefensas para "refundar la Patria" por el cual ya fueron llamados a indagatoria cinco congresistas (Semana, 2007).

En medio del aumento de los debates de control político, más los testimonios de varios desmovilizados y familiares de víctimas, dos casos sobresalieron: en el primero, Petro anunció un debate sobre el paramilitarismo en Antioquia que involucró a familiares del entonces presidente Álvaro Uribe y al senador Rubén Darío Quintero. Y el segundo, la captura de seis alcaldes de Casanare por hacer pactos con las autodefensas de Martín Llanos.

A raíz de estas investigaciones, los primeros congresistas apresados fueron Álvaro García Romero del Partido Colombia Democrática, Jairo Merlano del Partido de Unidad Nacional y Erick Morris también del Partido Colombia Democrática. Todos los procesados 
eran oriundos del departamento de Sucre y eran miembros de la bancada uribista en el Congreso. Álvaro García fue condenado por desplazamiento forzado y por promover masacres de campesinos en Sucre.

Además de los debates de control político en el congreso, las audiencias de los Tribunales de Justicia y Paz sirvieron como escenario para desentrañar las profundas relaciones entre políticos y paramilitares. "Desde mediados de 2006, la justicia se topó con un gran número de pruebas que pusieron al descubierto los nexos entre líderes políticos y funcionarios regionales y nacionales, con grupos paramilitares que operaron en distintas partes de la geografía nacional” (Verdad Abierta.com 2010). De acuerdo a la Corporación Nuevo Arcoiris, a julio de 2010, existían procesos por vínculos con el paramilitarismo contra 3 gobernadores, 5 alcaldes y 6 concejales elegidos para el periodo 2007-2011, y contra 16 ex gobernadores, 38 ex alcaldes, 12 ex diputados, y 21 ex concejales elegidos para periodos anteriores.

En lo que correspondía al legislativo, el escándalo de la parapolítica se desarrolló en fases. En la primera fase, fueron condenados Miguel de la Espriella, Juan Manuel López Cabrales, Rocío Arias, Eleonora Pineda, Mauricio Pimiento, Luis Eduardo Vives, Dieb Maloof, entre otros. En la segunda fase, se abrieron procesos contra Álvaro Araújo, Dixon Tapasco, Vicente Blel y Jorge Castro Pacheco, de igual manera a los exgobernadores Hernando Molina Araújo y Salvador Arana. La condena de Salvador Arana, exembajador de Álvaro Uribe en Chile, se produjo al concluirse que era responsable del asesinato de Eduardo León Díaz, exalcalde del municipio de El Roble, quien denunció ante Álvaro Uribe en el 2003 las amenazas de las que era víctima por parte de paramilitares. 
La tercera fase, incluyó procesos como el de Miguel Ángel Rangel, Carlos García, Humberto Builes y Juan Carlos Martínez, así a como el de Jorge Noguera, ex director del DAS, Guillermo Valencia Cossio, ex director regional de Fiscalías de Medellín y Mario Uribe, primo del expresidente Álvaro Uribe.

Para entender dichas relaciones entre políticos y paramilitares, se hace necesario analizar las formas en las que llegaron a sitios en común para defender intereses en común. En ese sentido, los acuerdos, pactos y reuniones celebradas entre 2001 y 2003 en distintos lugares de Colombia, reflejaban tres tendencias: los paramilitares buscaban a los políticos para construir un proyecto conjunto, los políticos buscaban paramilitares para obtener respaldo en épocas electorales y los acuerdos en donde los paramilitares garantizaban votos a cambio del control presupuestal de municipios y departamentos. Uno de los acuerdos más relevantes definitivamente es el de Santa Fe de Ralito. "El pacto de Ralito", convocado por Salvatore Mancuso, contó con la asistencia de más de 100 políticos y funcionarios de Córdoba, Sucre, Bolívar y Magdalena y jefes paramilitares que ya ejercían control sobre esos departamentos. Su propósito era "construir un proyecto político desde el paramilitarismo bajo las premisas de 'refundar la patria', 'crear un nuevo pacto social' y 'construir una nueva Colombia"” (Verdad Abierta, 2010).

Entre los firmantes estaban Salvador Arana (ex gobernador de Sucre, condenado a 40 años de cárcel), Jesús María López (ex gobernador de Córdoba con proceso pendiente), Alfonso Campo Escobar (ex representante por Magdalena condenado a 6 años de prisión), William Montes (ex senador de Bolívar con proceso archivado), Juan Manuel López Cabrales (ex senador condenado a 74 meses de prisión), Luís Carlos Ordosgoistia (ex representante a 
la Cámara por Córdoba, absuelto) y Miguel de la Espriella (ex representante a la Cámara por Córdoba condenado a 45 meses de prisión), entre otros (Verdad Abierta, 2010).

En el Pacto de Casanare, las Autodefensas Campesinas del Casanare y la clase política de dicho departamento se aliaron. Los primeros para recibir recursos de las arcas públicas y los segundos para ganar elecciones a raíz de las presiones e intimidaciones. En este pacto firmado por los paramilitares de Martín Llanos y seis alcaldes del departamento, "existía el compromiso otorgar el $50 \%$ del presupuesto municipal y el $10 \%$ de los contratos de los municipios a los paramilitares" (Verdad Abierta, 2010).

El Pacto de Chivoló, promovido por Jorge 40 y convocado por Neyla Alfredina Soto, se desarrolló con el propósito de definir y acortar el número de candidatos apoyados por las estructuras paramilitares en las elecciones de marzo del 2001. "Testigos dicen que a la reunión asistieron mil personas y finalmente firmado por 13 candidatos a alcaldías y 395 aspirantes a concejos y asamblea" (Verdad Abierta, 2010).

En uno de los predios de Jorge 40, la fiscalía encontró un documento titulado “Convenio político para el debate electoral del 10 de marzo de 2002, en la elección de Cámara de representantes y Senado de la República”, denominado por la opinión pública y la oposición como el Pacto de Pivijay. En él, políticos como José Gamarra Sierra, Dieb Maloof y Jorge Castro acordaron que los votos que se lograran en dichas elecciones en marzo del año 2002 en los municipios de Pivijay, Sabanas de San Ángel, Ariguaní, Algarrobo en donde José Gamarra Sierra contaba con bastante potencial electoral, le serían endosados a Dieb Maloof Cuse quien encabezaría la lista al Senado (Verdad Abierta, 2010). 
Con el Pacto de Caldas, Ernesto Báez desarrolló una estrategia similar a la de Jorge 40 en la Costa Atlántica, con el fin de establecer una especie de distritos electorales controlados por las estructuras bajo su mando y así disponer del control político respaldado por el aparato paramilitar. De esta manera se dio inicio al plan de expansión paramilitar en la zona de Caldas y Risaralda en el 2003.

De todos estos pactos, redes de colaboración y utilización bilateral de la política y las armas para fortalecer el poder regional, la Corte Suprema de Justicia ha proferido varias sentencias que se destacan no por la condena, sino por la reconstrucción realizada de la forma detallada en que se tejieron dichas alianzas que buscaban "refundar la patria". Por ejemplo, Jorge Castro Pacheco fue condenado a 90 meses de prisión y 6.500 salarios mínimos legales mensuales por sus nexos con el paramilitar Jorge 40 y por promover la creación de grupos paramilitares.

La sentencia de la Corte confirma que Castro Pacheco "se unió a una causa paramilitar... del saber que estuvo y participó activamente, en por lo penos una de las reuniones convocadas y controladas por "Jorge 40", comandante del Bloque Norte de las autodefensas, donde pactó su inclusión en la lista al Senado de la República secundando a Dieb Maloof Cuse, al igual que la alternancia de la curul siguiendo los lineamientos de un proyecto político-paramilitar, que después se materializó” (Verdad Abierta, 2010).

Al exembajador de Colombia en Chile, Salvador Arana, la Corte lo condenó a cuarenta años de cárcel y a una multa de más de 2.300 millones de pesos, no sólo por sus vínculos con el paramilitarismo sino por su responsabilidad en el ya mencionado asesinato del exalcalde Eudaldo Díaz (El Tiempo, 2009). A partir de testimonios recopilados por los investigadores de la Corte, se logró determinar que “Arana 'generó' en 'Cadena', el entonces 
jefe paramilitar en esa región costeña, 'la definitiva resolución' de cometer el homicidio del mandatario municipal” (El Tiempo, 2009).

La Corte Suprema de Justicia condenó también al excongresista Álvaro García Romero por ser el autor intelectual de la masacre de Macayepo, hecho en el que fueron asesinados 15 campesinos el 16 de octubre del año 2000. De acuerdo con el Tribunal, García Romero asistió a una reunión en la finca Las Canarias, propiedad de Miguel Nule Amín, donde se tomó la decisión de conformar el Bloque Héroes de los Montes de María de los paramilitares.

Como se puede evidenciar con los hechos anteriormente descritos, la relación paramilitar con políticos logró desentrañarse no sólo gracias a las versiones libres de Justicia y Paz, sino también producto de la labor legislativa y de los órganos judiciales y tribunales que no lograron ser cooptados por los aliados paramilitares. Sin lugar a duda, la parapolítica ha sido uno de los fenómenos con mayor trascendencia nacional, pues permite analizar la forma en que el ejercicio del poder y la dominación a nivel regional y local en Colombia, ha utilizado la violencia y se ha valido de estructuras armadas que han afianzado el amplio gamonalismo y a su vez, la capacidad económica de quienes se lucraron de la violencia paramilitar.

\section{Juan Manuel Santos y El Proceso de Paz. ¿Inicio de un nuevo período?}

Aunque Juan Manuel Santos fue elegido en el 2010 como el sucesor de la política de Álvaro Uribe Vélez, rápidamente se desmarcó de su antecesor en la forma de abordar el 
conflicto armado interno. Sin embargo, es importante resaltar que en materia económica, política y social, significó la continuidad del modelo de desarrollo del anterior mandato, profundizando la importancia del sector primario de la economía, específicamente la "locomotora" minero energética, la producción de biocombustibles aumentando los cultivos de palma de aceite, caña y maíz y la consolidación de las Zonas de Interés de Desarrollo Rural, Económico y Social (ZIDRES), lo que promovió la entrega de baldíos de la nación que por ley deben ser adjudicados a campesinos desplazados-, a empresas multinacionales.

Sin embargo, en lo que respecta al conflicto armado, el presidente Juan Manuel Santos se distanció del expresidente Álvaro Uribe Vélez, en tanto le apostó a dialogar en medio de la confrontación con la guerrilla de las FARC-EP. En el libro Así empezó todo (2014) Enrique Santos describe la forma en que los diálogos exploratorios dan inicio:

A las 10:30 en punto estamos sentados en una reducida y alargada mesa en la Casa de Piedra. Al frente, a menos de dos metros, los delegados de las Farc; y en los dos extremos, los garantes de Noruega (Dag Nylander y Elizabeth Slaattum) y de Cuba (Carlos Fernández de Cossio y Abel García). La sesión introductoria se inicia con palabras de bienvenida del delegado cubano [...] El hombre va al grano: Cuba quiere brindar lo necesario: garantías de seguridad y discreción para llevar a cabo el encuentro exploratorio [...] La paz de Colombia es prioridad para Cuba y hay precedentes de la participación cubana en este tipo de acercamientos. Habla a continuación el delegado de Noruega, Dag Nylander, joven pero experimentado funcionario de su Cancillería, con mucho recorrido en el tema del conflicto armado colombiano. Enumera entonces las razones de Noruega para participar en iniciativas de paz a nivel mundial: reducir el sufrimiento asociado a conflictos armados; 
convicción de que los conflictos se resuelven con diálogos; promoción de la paz a nivel mundial por razones de seguridad nacional propias. Las motivaciones de Noruega son tanto humanitarias como de interés propio (Citado en Semana, 2017).

Mientras se adelantaban las fases secretas con las FARC-EP, en Colombia la situación social y política se avivaba con los paros nacionales decretados por diversos sectores sociales. En el 2011, la Mesa Amplia Nacional Estudiantil (MANE) organizó uno de los paros estudiantiles más grandes desde el movimiento de 1971, con el fin de impedir el proyecto de reforma a la Ley 30 de educación superior. Desde los años 70, ningún grupo de estudiantes colombianos había logrado algo similar a lo que ocurrió con la Mesa Amplia Nacional Estudiantil (MANE) en noviembre de 2011. Miles de personas salieron a protestar pacíficamente para pedirle al gobierno de Juan Manuel Santos, y a su ministra de Educación, María Fernanda Campo, que detuvieran la reforma a la Ley 30 de educación superior (El Espectador, 2014).

Esta situación coincidió con el aumento de las protestas y paros organizados por estudiantes en Chile, los Indignados en España y Grecia y los Ocuppy en Estados Unidos, así como las acciones de diversos grupos políticos afectados por la reciente crisis económica del 2009. La globalización de las demostraciones de movilización popular a través de la inmediatez de las nuevas comunicaciones jugó un papel fundamental para influir en las decisiones de miles de jóvenes que tenían un vago recuerdo de la movilización estudiantil potente de los años 70. Aunque Juan Manuel Santos intentó desconocer en un inicio la movilización de la MANE y su capacidad de convocatoria, la presión realizada en escenarios académicos, de debate y de protesta surtieron sus primeros efectos: la paralización de la reforma. 
Desde agosto del 2011, organizaciones estudiantiles de distintas tendencias confluyeron en la oposición a la reforma construcción de una propuesta concreta para presentarle al gobierno de Santos, con el fin de evitar la privatización de la educación pública y su carácter crítico. E1 10 de octubre miles de estudiantes organizados en la MANE arribaron a Bogotá desde distintas regiones del país para paralizar la capital de Colombia en lo que denominaron "la Toma de Bogotá". Estas expresiones de acción colectiva y de organización social se convirtieron sin lugar a duda en el primer precedente para el nuevo gobierno de que el movimiento social colombiano había resurgido de un largo letargo (en el 2008 se dio la última movilización popular masiva de la primera década del Siglo XXI).

El gobierno se equivocó porque creyó que la socialización de una reforma sobre un tema trascendental y que afecta a un sector deliberativo y complejo se limitaba a convocar unos foros. La ministra María Fernanda Campo confundió presentación con conciliación, y explicación con concertación. El caso es que el solo anuncio de la reforma, en marzo, tuvo pésima acogida y alebrestó a un movimiento estudiantil que llevaba años dormidos. La propuesta gubernamental de crear universidades con ánimo de lucro, de aumentar los créditos educativos, de darles un mayor peso a las universidades técnicas y tecnológicas, logró unir en un frente común a los rectores de las universidades públicas y privadas en contra de la iniciativa del gobierno. Como lo dijo el portal Lasillavacia.com, "llegar con una actitud de gerente del sector privado - sin ningún tipo de respaldo técnico ni político- a imponer una agenda polémica era la receta para el caos" (Semana, 2011).

El año 2012 fue catalogado por muchos como el año de las protestas ambientales. A raíz de la puesta en marcha de la "locomotora" minero energético y la profundización de las diferencias en términos de modelos de desarrollo social y ambiental, muchas comunidades 
desarrollaron acciones en lo que ellos denominaron: "defensa del territorio y la vida". Así, indígenas de la Sierra Nevada de Santa Marta desarrollaron movilizaciones para evitar la construcción de un megahotel en el Parque Tayrona. Los habitantes de Garzón y Gigante, en el departamento del Huila alzaron su voz de protesta en contra de la hidroeléctrica El Quimbo, y los campesinos del suroeste antioqueño decidieron frenar la avanzada de la minería a gran escala en sus territorios. De acuerdo con César Padilla, director del Observatorio de Conflictos Mineros en América Latina, este aumento de movilizaciones y de acciones colectivas, insiste en que es un fenómeno que ha emergido en la mayoría de países de Suramérica, especialmente en Perú y Chile: "Las comunidades dudan de los proyectos mineros o energéticos, porque no les han cumplido lo que prometen”. Para Padilla es claro que la serie de promesas no se ha visto reflejado en el desarrollo de las comunidades en las que operan las empresas. Por eso insiste en que "las organizaciones se han encargado de tomar decisiones frente a la implementación de proyectos, porque saben que son pocos los beneficios para las poblaciones" (El Espectador, 2012).

Los casos más emblemáticos para el 2012 en términos de organización social y defensa del territorio fueron: 1. el de los habitantes del municipio de Marmato contra la minera Gran Colombia Gold; 2. La ya mencionada hidroeléctrica El Quimbo; 3. La defensa del Páramo de Santurbán; 4. Hidroituango y 5. La defensa del Río Ranchería.

1- De acuerdo con líderes sociales de Marmato, el Gobierno Nacional tomó la decisión unilateral de reubicar el municipio alegando fallas geológicas e inestabilidad del suelo. Sin embargo, en el trasfondo del asunto aparece la cifra de 11,8 millones de onzas de oro y 90 millones de onzas ubicadas en el territorio. 
2- La ya mencionada movilización contra la construcción de la hidroeléctrica El Quimbo. Durante enero del 2012, varios campesinos bloquearon las obras para impedir el acceso a trabajadores y equipos con el fin de que se realizara una audiencia pública ambiental. Miller Desván, líder de Asoquimbo, ha afirmado que a pesar de que los planes de la empresa continúan su curso, la movilización social en los municipios de Gigante, Garzón, Altamira, El Agrado, Tesalia y Paicol ha dado resultados: la Contraloría advirtió que hay irregularidades en el censo de afectados y en la licencia ambiental. Además, que la empresa habría causado un detrimento patrimonial superior a los $\$ 350.000$ millones, debido a los daños sociales, ambientales y económicos generados con la intervención. Sumado a esto, el Instituto Colombiano de Antropología e Historia multó con \$250 millones a Emgesa, por los daños ocasionados a piezas arqueológicas (E1 Espectador, 2012).

3- La defensa del Páramo Santurbán. Luego de conocerse el rechazo a la solicitud de la minera Greystar Resources Ltda (hoy EcoGold) para explotar oro en el páramo de Santurbán, las comunidades santandereanas de las zonas aledañas al páramo han decidido movilizarse y organizarse para impedir la ejecución de 144 títulos mineros y para que la nueva delimitación de las zonas de páramo no afecte la biodiversidad y el equilibrio ecosistémico del territorio.

4- Hidroituango. Sin lugar a dudas, este proyecto hidroeléctrico minado de fallas e inconsistencias desde si planeación ha movilizado a miles de personas no sólo en los territorios aledaños al cañón del río Cauca, sino en gran parte del territorio nacional. Los afectados por el proyecto adelantado en el norte de Antioquia, han hecho "varias 
manifestaciones y bloqueos exigiendo que se suspenda la obra" (El Espectador, 2012). A finales del 2018 e inicios del 2019 se vivió una de las situaciones más críticas en términos sociales y ambientales, pues las poblaciones cercanas al proyecto tuvieron que ser evacuadas ante una inminente inundación. De igual manera, la disminución de los niveles del caudal del río producto de generó un desequilibrio biológico que afectó varias especies de peces y de vegetación.

La defensa del río Ranchería. Al conocerse el interés por parte de la empresa explotadora de carbón “El Cerrejón” de desviar el cauce de 26 km del río Ranchería, las comunidades de La Guajira, ambientalistas y miembros de organizaciones sociales se movilizaron para impedir esta intervención. Tal fue la magnitud de la movilización y del impacto mediático, que el ministro de Ambiente y Desarrollo Sostenible, Juan Gabriel Uribe, reconoció que "la fuerte oposición que he visto por parte del Congreso y de algunas comunidades me hace pensar que el proyecto no parece viable" (El Espectador, 2012).

El 2013 fue un año de suma importancia para el movimiento campesino. En junio de ese año, los campesinos de la región nortesantandereana del Catatumbo se volcaron a las vías para exigir atención integral por parte del gobierno nacional. La pobreza, el paupérrimo estado de las vías, la falta de hospitales y la baja calidad de vida fueron los detonantes para que 17.000 campesinos de los municipios de Tibú, Hacarí, Teroama, San Calixto, El Tarra, Táchira y Convención decidieran organizarse y movilizarse. 
Dos de las causas principales para el inicio del Paro del Catatumbo fueron la erradicación forzada de cultivos ilícitos y la exigencia al gobierno nacional de decretar la Zona de Reserva Campesina del Catatumbo. Durante 53 días, el movimiento campesino del Catatumbo se mantuvo en organización y movilización, a pesar de los intentos de la policía y el ejército de amedrentar a quienes decidieron hacer uso del legítimo derecho a la protesta.

El objetivo de nuestro paro campesino era la exigencia del cumplimiento de la constitución de la Zona de Reserva Campesina, que desde el año 2009, en el marco del Refugio Humanitario "Por la Vida, La Dignidad, La Tenencia de la Tierra y La Permanencia en el Territorio", veníamos trabajando con el gobierno, donde la inversión para los estudios y la delimitación han sido cuantiosos pero sin respuestas concretas al campesinado Catatumbero, quien guarda la esperanza de algún día poder tener constituida la ZRCC y la ejecución de su Plan de Desarrollo Alternativo, construido por las propias comunidades, quienes han identificado cuáles son sus reales necesidades y que proyectan para el futuro y el desarrollo de la economía campesina Catatumbera (Agencia Prensa Rural, 2014, pág 6).

Luego de los 53 días del Paro Catatumbero, el 29 de agosto de 2013 organizaciones campesinas de toda Colombia decidieron movilizarse en contra del TLC con EE.UU. y la Unión Europea, exigir la congelación de los precios de los insumos agrícolas, la disminución de los intereses a los créditos agrarios y la protección de las cosechas a partir del financiamiento de una parte de las mismas. 
Lo que inició como una protesta sectorial, convocó a estudiantes, obreros, maestros y sindicatos a solidarizarse con el movimiento campesino que no veía desde los años 80 un poder de movilización de magnitud nacional. De acuerdo a cifras de las organizaciones sociales, la represión policial dejó 12 muertos, 485 heridos (21 con arma de fuego) y 4 desaparecidos, sin sumar los cientos de detenidos y judicializados por sumarse a la movilización social y popular. Sin lugar a duda, el paro nacional agrario del 2013 significó no sólo el reavivamiento del movimiento agrario, sino que permitió identificar al campesino como un sujeto de derechos que despierta simpatía y solidaridad en las bases sociales que poca o nula participación habían tenido en procesos de este tipo. De hecho, la declaración de Juan Manuel Santos, quien afirmó que "el tal paro (nacional) agrario, no existe" despertó con mayor fuerza la indignación y el apoyo de masas a la movilización campesina.

El 2014 se desarrolló como un año de convergencias en torno a un objetivo fundamental para la mayoría de organizaciones que en años anteriores habían decidido movilizarse en contra de las políticas de paz de Juan Manuel Santos. En el año 2012 se conoció que el gobierno colombiano y las FARC-EP habían entrado en la etapa pública de diálogos y la agenda electoral del 2014 cada vez más tenía en su epicentro las conversaciones de La Habana. Aunque la opción política de izquierda representada en Clara López Obregón no logró captar los votos suficientes para pasar a segunda vuelta, Santos, quien aspiraba a su segundo mandato se enfrentaba al candidato del uribismo -férreos opositores al proceso de paz-: Oscar Iván Zuluaga. De esta manera, la gran mayoría de sectores sociales y políticos que le apostaban a la salida dialogada al conflicto tomaron la decisión de apoyar a Juan Manuel Santos, quien adquirió el compromiso de llevar a buen término los Acuerdos de Paz. 
Resulta interesante entonces analizar la forma en que la coyuntura nacional pasó de un año con gran convulsión social y de amplios procesos de movilización en el país en contra de las políticas neoliberales de Santos, al apoyo necesario en términos electorales para fortalecer el proceso de paz de La Habana y blindar de los opositores, la salida negociada al conflicto armado colombiano. De esta manera, se puede evidenciar que la agenda nacional en términos de movilización sectorial disminuyó para rodear el intento de diálogo con la insurgencia, intento que se veía cercano luego del fracaso del Caguán.

En el 2015 las organizaciones sociales y muchos miembros de los partidos políticos defensores del proceso decidieron convocar a la marcha por la Paz el 9 de abril ${ }^{16}$. Aunque los miembros de la oposición y las organizaciones de base convocaron a la movilización por la "paz con justicia social", los adeptos al gobierno Santos convergieron con los movimientos sociales en la necesidad de continuar con el proceso de paz y en la defensa de la oportunidad histórica que se avizoraba.

En el 2016 el proceso de paz entró en un estado crítico. Luego del plebiscito por la paz en el que ganó la opción apoyada por el uribismo -abiertos opositores a los diálogos-, miles de estudiantes se volcaron a las calles para exigirle al gobierno nacional la continuación de los diálogos. Bajo el lema "que se cumpla lo pactado", más de 100.000 personas en todo el país decidieron movilizarse para defender el acuerdo de paz. Mientras esto sucedía, las bases guerrilleras ya reunidas en las Zonas Veredales ${ }^{17} \mathrm{y}$ Puntos de Agrupamiento pactados por el acuerdo, vivían en un estado constante de incertidumbre y zozobra.

\footnotetext{
${ }^{16}$ En conmemoración del 9 de abril de 1948, cuando el líder liberal Jorge Eliécer Gaitán fue asesinado en Bogotá. Este hecho causó una nueva ola de violencia que, para muchos académicos, significó el inicio de la violencia sociopolítica.

${ }^{17}$ Se define Zonas veredales a territorios temporales y de transición para los grupos de las FARC
} 
El respaldo popular al proceso de paz y la voluntad política de las partes en diálogo, permitió realizar algunas modificaciones a lo pactado con las FARC-EP y de esta manera, firmar el Acuerdo Final para la Terminación del Conflicto y la Construcción de una Paz Estable y Duradera en el Teatro Colón de la ciudad de Bogotá el 24 de noviembre del 2016. Así la fase de ejecución del Acuerdo de La Habana daba inicio. El desarme de las bases guerrilleras y la incorporación de las FARC-EP como partido político iniciaba, y el país que había conocido a la insurgencia de origen campesino fundada en Marquetalia en 1964, se encontraba con una incipiente apertura democrática al partido Fuerza Alternativa Revolucionaria del Común (FARC).

En el 2017 se reanuda la dinámica del movimiento social. Sin embargo, las presiones a partir de multitudinarias marchas y procesos de movilización local, regional y nacional tienen como fin exigirle al gobierno de Santos la aplicación de los puntos acordados en el Acuerdo de La Habana. Así pues, las regiones priorizadas para la inversión social en el marco del posconflicto desarrollaron jornadas de protesta para presionar el inicio de la construcción de los Planes de Desarrollo Territorial (PDET), la erradicación voluntaria de cultivos de uso ilícito y la atención integral a las comunidades cocaleras, la puesta en marcha de la Comisión de la Verdad y la reglamentación jurídica para el tribunal de la Jurisdicción Especial de Paz (JEP). 


\section{CAPITULO II}

\section{MUJER RURAL, POLÍTICAS PÚBLICAS Y ORGANIZACIÓN CAMPESINA}

\subsection{Organización campesina y lucha por la tierra: breve recuento histórico}

De acuerdo con el estudio realizado por Héctor Mondragón (2002), los primeros visos de organización campesina se pueden rastrear hasta la región Caribe en 1905 con la movilización contra el sistema feudal de la "matrícula", el cual consistió en la descentralización del poder de la tierra, donde los campesinos estaban en la base de la pirámide y a su vez sometía a los descendientes de los esclavos. El líder de esta lucha fue Manuel Hernández "El Boche” y da sus primeros resultados en 1921 cuando Vicente Adamo y Juana Julia Guzmán dirigen el movimiento. En 1907 en Montelíbano, Córdoba, Eduardo Marchena orienta el movimiento de colonos y Carlos Massenet en 1928 encabeza la movilización campesina contra una compañía inglesa. Mientras esto sucedía en el norte de Colombia, en el suroccidente surge la lucha de Quintín Lame. En 1914 la organización indígena toma fuerza en el Cauca y en 1915 se realiza un alzamiento indígena. Quintín Lame es encarcelado y se le da el estatus de insurrecto. Después de cinco años de prisión, el líder indígena huye al Tolima y su lucha se extiende en este departamento y en el Huila, al interior del país. Con representantes de comunidades indígenas y algunas campesinas del Tolima y Cauca se establece en 1920 el Consejo Supremo de Indias (Mondragón, 2002). 
Para evitar la expansión de las ideas del Consejo Supremo de Indias y su influencia política en temas de titulación de tierras y reforma agraria, los terratenientes apoyados por las fuerzas militares y gamonales políticos cometen masacres como la de Inzá (Cauca) en noviembre de 1916, la de Caguán (Huila) en marzo de 1922 y la de Llano grande en Ortega (Tolima) en 1931. En Cundinamarca, específicamente en la región del Sumapaz, Eufrosina Molina dirige el movimiento campesino de 1912 que realizaba procesos de ocupación de tierras apropiadas ilegalmente por terratenientes y gamonales políticos de la época. Para contrarrestar el emergente movimiento agrario en el Sumapaz, en 1916 los terratenientes crean uno de los primeros grupos paramilitares en esta región llamado Los Fieles (Mondragón, 2002).

Los logros de la organización campesina comienzan en 1926 con la aprobación de la Ley 74 que reconoce la función social de la propiedad. Entre finales de los 20 y comienzos de los 30 se consolidan las Ligas Campesinas y el Partido Agrario Nacional (PAN), dirigido por Erasmo Valencia en el Sumapaz, la Unión Nacional de Izquierda Revolucionaria (UNIR) fundada por Jorge Eliécer Gaitán y el Partido Socialista Revolucionario (PSR) del que surgiría más adelante el Partido Comunista Colombiano (PCC). La influencia de las agrupaciones anteriormente mencionadas se distribuye geográficamente en el centro del país de la siguiente manera: el PAN en la parte alta del Sumapaz, el PCC en Viotá y la UNIR en Silvania y Granada.

Un aspecto importante de esta relación fue la organización de sindicatos de obreros rurales. El principal de ellos fue el de las bananeras de Santa Marta, masacrado para reprimir su huelga, el 6 de diciembre de 1928, pero revivido posteriormente. Los trabajadores de las 
trilladoras y las escogedoras de café mantuvieron también un movimiento muy activo por sus derechos (Mondragón, 2002, p. 26).

Aunque el movimiento campesino comenzaba a consolidar organizaciones con cierta formación política que pretendía una interrelación de corrientes, la carencia de una organización de carácter nacional que aglutinara los distintos grupos y la reorientación de algunos de los líderes agrarios al reformismo liberal debilitó la lucha popular luego de 1936. Paralelamente a este debilitamiento, los terratenientes fundan la Asociación Patriótica Económica Nacional (APEN) en 1934 para oponerse a la reforma agraria propuesta por la confluencia de movimientos campesinos mencionados y apoyar la Sociedad de Agricultores de Colombia (SAC).

A pesar de la débil participación del movimiento campesino en el espectro político, el gobierno liberal de 1936 aprobó la Ley 200, uno de los primeros intentos institucionalizados de reforma agraria en el país. De hecho, no se habló de reforma agraria en su momento, sino de una ley de tierras que buscaba apaciguar la fuerza de un movimiento campesino que, aunque no tenía amplia participación política si constituía un fuerte movimiento de masas.

En la ley 200 se plasmaron elementos de trascendencia para el sector agropecuario. Dos de ellos fueron:

1. La creación de la Jurisdicción Agraria con la existencia de jueces especializados en dirimir conflictos de tierras. 2. La introducción de la figura de la Extinción del Dominio o pérdida de la propiedad como resultado del incumplimiento 
de su función social, cuando el propietario deja sin explotación económica la tierra durante un lapso determinado (Mondragón, 2002, p.27).

A la Ley 200 de 1936 reaccionaron los terratenientes de la APEN con la aprobación de la Ley 100 de 1944. Esta ley declaró de conveniencia pública los contratos de aparcería, una de las formas más relevantes de sujeción del campesino sin tierra a la propiedad terrateniente.

Dos años antes del inicio de la época de La Violencia (1946-1954), se funda la Federación Campesina e Indígena quien lideró acciones de movilización en rechazo de la Ley 100 del 44 y contra las acciones de terratenientes de la APEN. La Federación tenía fuerte influencia en Cundinamarca, Tolima, Cauca, Huila, Magdalena, Bolívar, Caldas, Santander y el Valle. Sin embargo, con la arremetida de la violencia política, se incrementaron los ataques a dirigentes campesinos y sus bases en Tolima, Huila, Cundinamarca y Santander.

La Violencia creciente desde 1946 se incrementó con los ataques a Viotá en noviembre de 1947 y contra las comunidades del Cauca en enero de 1948. El siguiente 9 de abril, día del asesinato de Jorge Eliécer Gaitán marcó un momento de generalización de esa Violencia que se ensañó contra la Confederación. Cobró la vida de la mayoría de sus dirigentes, entre ellos, la de su presidente, envenenado en 1952. Las organizaciones campesinas e indígenas quedaron prácticamente destruidas, incluso la Liga de Indios de la Sierra Nevada de Santa Marta, que había logrado mantenerse gracias al relativo aislamiento geográfico, se disolvió en 1956. De esta dinámica se salvaron la Federación Agraria Nacional, Fanal, fundada en 1946 con el apoyo de la Iglesia Católica, y la Unión de Trabajadores de Colombia, UTC (Mondragón, 2002, p.29). 
En cuanto al campesinado, ya veíamos que su presencia pública en los años cincuenta era difusa, salvo en algunas zonas de colonización en donde hubo resistencia durante los años de la violencia. El proyecto de reforma agraria pareció despertar al gigante dormido, sobre todo cuando el reformismo de Carlos Lleras se empeñó en organizarlo (Archila, 2018, p. 392).

Paralelamente a la agudización de la violencia, se crea el Instituto de Parcelaciones y Colonización mediante el decreto 1483 del 11 de mayo de 1948 (Sistema Único de Información Normativa, 1948). Este Instituto se origina con el fin de impedir la lucha por la reforma agraria y la consolidación de la ejecución de la Ley 200 de 1936 a través de un mercado de tierras y crédito hipotecario para campesinos pobres y sin tierra. A pesar de esto, en 1952 pasó a llamarse Instituto de Colonizaciones y su gestión sólo permitió la compra de cinco haciendas para unas pocas familias, durante este tiempo, miles de campesinos comenzarían las largas migraciones hacia territorios nacionales -en los llanos orientalespara huir de la guerra desatada. Así pues, La Violencia fue:

...la materialización del proyecto de la APEN por la vía del conflicto conservador-liberal, pero con efectos muy precisos: además de que se liquidó la organización campesina e indígena y se desconocieron sus conquistas, hubo 2 millones de campesinos desplazados, 200 mil más asesinados y el despojo de sus tierras en áreas agrícolas (Mondragón, 2002, p. 29). 
De esta manera desaparecieron paulatinamente conquistas logradas en términos de titulación y acceso a tierras. Las organizaciones campesinas e indígenas se disolvieron en Córdoba, así como el resguardo de Ortega y Chaparral. De igual manera, en el Cauca se desconocieron -nuevamente-, títulos prediales para las organizaciones indígenas y se agudizó el "terraje"18.

Como resultado muchos territorios en el sur del Tolima, los Llanos Orientales, la provincia del Tequendama y el Sumapaz vieron emerger una serie de grupos de resistencia, algunos de carácter liberal y otros de carácter comunista. En Sumapaz, Juan de la Cruz Varela sería uno de los líderes de las Ligas Agrarias que más adelante pasarían a ser parte del Partido Comunista. Mientras en el sur del Tolima nace el Bloque Sur como autodefensa campesina liberal, que posteriormente se convertiría en las FARC bajo el liderazgo de Pedro Antonio Marín -quien luego se adheriría al Partido Comunista-. "También lo hicieron los indígenas de Yaguará (Tolima), quienes solamente con las armas en la mano mantuvieron sus tierras" (Mondragón, 2002, p. 30).

A hoy, existe un sinnúmero de organizaciones campesinas que continúan en la lucha por la tierra, la paz, la vida digna, las Zonas de Reserva Campesina, las cuales son extensiones de tierra con características ambientales, agrícolas, económicas, ecológicas y sociales propias para el ordenamiento de un territorio y la defensa de los territorios. Entre ellas destacan: la Asociación Campesina del Valle del Cimitarra (comarca entre Yondó y San Pablo) la cual mantiene muy buenas relaciones con Fensuagro; la Asociación Nacional de Zonas de Reservas Campesinas; la Asociación Nacional de Usuarios Campesinos (ANUC); la Asociación Nacional para la Salvación Agropecuaria de Colombia; la Unidad Cafetera; el

\footnotetext{
${ }^{18}$ Pago en trabajo a los hacendados por permitir cultivar una parcela.
} 
Consejo Nacional Campesino; la Asociación Campesina Colombiana; la Asociación Nacional de Usuarios Campesinos-Unidad y Reconstrucción (ANUC-UR); la Asociación Nacional de Mujeres Campesinas e Indígenas; la Coordinadora Nacional de Desplazados; la Federación Nacional de Cooperativas Agropecuarias;

\subsection{Federación Nacional Sindical Agropecuaria}

La Federación Nacional Sindical Unitaria Agropecuaria (FENSA), surge como una iniciativa de sectores políticos como el Movimiento Comunista Colombiano, y gremiales, como la Federación Sindical de Trabajadores de Colombia. Esta Federación tiene su origen en el primer Congreso del movimiento conmemorativo a la Masacre de las Bananeras el 6 de diciembre de 1976, donde se tocan los temas de la situación de afectación del Movimiento Campesino que data desde las acciones del Frente Nacional, generador de una violencia bipartidista generalizada hasta nuestros días, la desarticulación del movimiento campesino debido a la injerencia del gobierno del presidente Alfonso López Michelsen.

Dos años después de su establecimiento en 1978, FENSA junto con otras organizaciones crearon el Comité Nacional Agrario (CONA) a partir del propósito de conjugar y adelantar esfuerzos en torno a la realización de una reforma agraria integral en Colombia. Dicha reforma, según la propuesta generada por el CONA, implicaría la democratización en el proceso de la entrega de tierra, además de servicios sociales para el campo tales como asistencia técnica, salud, educación, vivienda, créditos, vías de acceso, entre otras (Fensuagro, 2006b). Un acumulado de desigualdades en el campo da origen a la lucha y resistencia del campesinado, indígenas y negros desde el siglo XIX. La violencia en 
Colombia, en especial en el campo, se ha utilizado para despojar a los campesinos y negros de sus territorios. Los colonos talan selvas para los latifundistas.

Como parte de su horizonte político, FENSA abogaba por la unidad obrera y campesina, así como el fortalecimiento de relaciones con el Partido Comunista, lo que le valió feroces enemigos del Estado colombiano y las fuerzas militares. En el V Congreso Nacional de FENSA desarrollado en 1987, se establece la transición de FENSA a FENSUAGRO, reafirmando su defensa de la economía campesina y la salida dialogada al conflicto armado. Esto significó también profundizar las convicciones políticas materializadas en el apoyo de las marchas cocaleras del sur del país, las recuperaciones de tierras y las colonizaciones dirigidas en el sur oriente, así como la participación en las últimas movilizaciones masivas del movimiento campesino, como el Paro Nacional Agrario del 2013. En este contexto, organizaciones como FENSUAGRO emergen con el propósito de posicionar las reivindicaciones por la tierra y las condiciones para la vida digna en el campo colombiano.

La formación de FENSUAGRO contó con la presencia del Sindicato Nacional de Trabajadores de la Industria Agropecuaria (SINTRAINAGRO). La organización busca defender los principios de lucha en contra de la opresión del capitalismo, de los terratenientes, latifundistas, transnacionales y políticas anti campesinas. Promulga una democracia progresista dirigida a los campesinos y trabajadores del campo; manifiesta una autonomía e independencia del Estado y de los partidos políticos.

Reclama la soberanía y seguridad alimentaria, protege la producción nacional agropecuaria, está en contra de los métodos y proyectos que causen daño a la salud humana, ambiental y al patrimonio de las comunidades. Promueve la realización de reformas agrarias 
que busquen la devolución e indemnización de tierras que están en manos del terrateniente y dedicadas a fines no agrícolas, al campesinado desplazado.

Propone garantizar el derecho a la tierra y demás derechos de la mujer campesina como jefa de hogar y establece igualdad de derechos a los integrantes de la familia; promulga la real participación de la mujer con poder de decisión en todos los niveles de la vida política, económica y social. Prioriza reformas de ley que garantice el alcance de beneficios para los campesinos como créditos, comercialización de productos, vivienda, salud, educación, defensa de los recursos naturales renovables y no renovables. Plantea objetivos sociales, es decir una sociedad basada en la transformación y la construcción de la justicia social para el obrero y el campesino. Según su análisis, el pacto crucial para América Latina es el despertar de la conciencia étnica entre los campesinos, que torna aún más difícil sostener su homogeneidad. (Archila, 2018, p. 394)

La Federación está integrada por grupos agrícolas y de transformación de productos pecuarios, producción animal y vegetales, comercialización, explotación, recursos naturales renovables y no renovables, cooperativas, empresas comunitarias, asociaciones de agricultores, juntas de acción comunal, organizaciones sindicales de los sectores mencionados y trabajadores de la agroindustria de protección de la ecología. La componen principalmente sindicatos campesinos departamentales y algunos municipales de Cundinamarca, Guaviare, Arauca, Cauca, Tolima, Huila, Atlántico, Nariño, Meta, Quindío, Boyacá y Bolívar; la Coordinadora de Cultivadores de Coca y Amapola y el Coordinador Nacional Agrario.

Las instancias de debate y tomas de decisiones de Fensuagro, cuentan con una Asamblea Nacional, la cual se reúne cada tres años para trazar las políticas de la federación; 
una Junta Nacional, compuesta por delegados elegidos en la Asamblea Nacional por las organizaciones afiliadas, cuyo objetivo es evaluar el desarrollo de las políticas de la Federación, trazan planes anuales para concretar líneas de acción acordados. Cuentan con un comité ejecutivo integrado por el presidente, vicepresidente, secretario general, tesorero y fiscal y su función es concretar y ejecutar los acuerdos; se resalta la labor de las secretarías de los Derechos Humanos; Economía campesina; Mujer y niñez; Educación, juventud y cultura; Prensa y propaganda; y Trabajos en la Agroindustria (Prensarural.org).

La violencia política afectó los alcances organizativos y unitarios, así como el crecimiento de la Federación, especialmente en regiones como la Costa Caribe y el Magdalena Medio, el Urabá Antioqueño y departamentos como Meta. En la región de Urabá, enclave económico de Colombia y epicentro de las luchas populares de los trabajadores bananeros, la Federación fue prácticamente exterminada como consecuencia directa de los asesinatos, las desapariciones forzadas, el desplazamiento forzado, las amenazas y otra serie de hechos violentos (FENSUAGRO, 2018, p. 18). 


\section{Imagen 1. Mural en la sede de FENSUAGRO, Viotá-Cundinamarca}

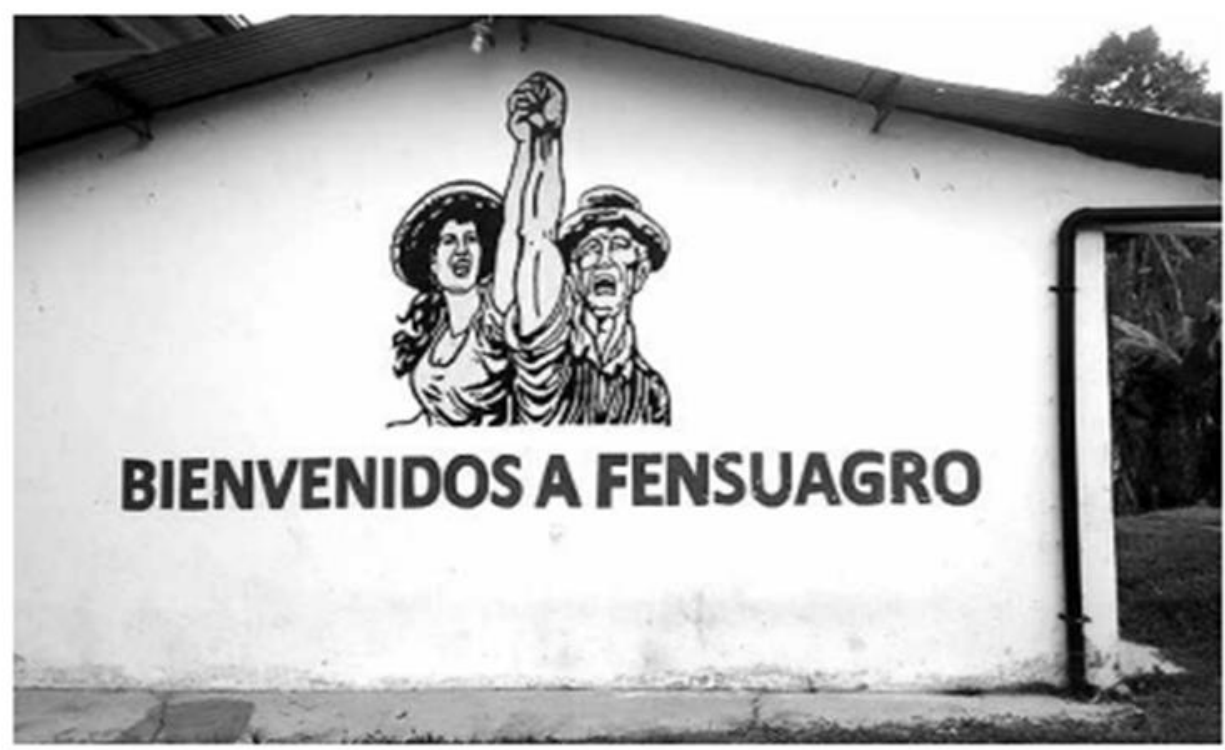

Mural en la sede de Fensuagro, municipio de Viotá, Cundinamarca

Para FENSUAGRO, el resultado del trabajo de la mujer campesina para apoyar en la consolidación de la economía del campo, constituye un papel relevante ya que emprende creaciones de métodos de subsistencia favorables desde su capacidad física, fuerza de trabajo y conocimientos en cuanto al tema. De esta manera y aunque aislada en el ámbito de la economía doméstica, la mujer campesina está inserta en el proceso productivo del campo.

En Colombia se violan los derechos más elementales, hecho que aumenta la violencia de nuestro país. La mujer ha sido sujeta y protagonista directa de estos hechos atroces de marginación, violación, abuso sexual y emocional. Además de los desvanes de la violencia, se incrementan las desigualdades en los niveles de escolaridad entre la mujer campesina y la mujer urbana y el respeto de sus derechos e igualdad de condiciones ante los hombres. 
La Federación busca empoderar y apoyar en la emancipación de la mujer campesina a fin de generar en ellas, el descubrimiento, valor individual, encontrar estrategias para abrirse espacios y organización en aras de enfrentar la sociedad discriminatoria y opresora.

"Desde nuestro espacio organizativo de FENSUAGRO, podemos ver ese principio de lucha en las tantas mujeres que están a diario en la conquista de los derechos colectivos para para sacar el lastre y el sometimiento que nos ha impuesto el yugo opresor; la presencia y participación de la mujer en el desenvolvimiento de la vida campesina colombiana resalta hechos importantes como la lucha con sus compañeros por la vida digna y justa de la tierra. (Prensarural.org. Prensa Rural).

\subsection{La mujer campesina en la organización agraria}

En el marco del conflicto y la violencia analizada con anterioridad, el hecho de ser mujer y ser campesina en Colombia ha significado para la mujer rural un reto pues la violencia en muchos casos las ha convertido en víctimas en varias formas (sexual, laboral, social y de familia). De acuerdo a organizaciones internacionales como Oxfam, las mujeres han sido víctimas antes y durante el conflicto armado no sólo por la inexistencia del reconocimiento de derechos como campesinas, sino por los roles de género que los núcleos familiares rurales del país han legitimado y definido a lo largo de la historia.

Según cifras del Departamento Administrativo Nacional de Estadísticas, DANE, para 2005 más de cuatro millones de mujeres habitaban en contextos rurales, de las cuales el 19\% eran madres cabeza de familia. De esta manera, las mujeres campesinas debían redoblar esfuerzos en el hogar: llevar a cabo jornadas de trabajo en la mayoría de los casos en 
condiciones paupérrimas y mal remuneradas y el trabajo doméstico que no es remunerado. Sin embargo, se considera que la mujer campesina en el país ha sido triple víctima por su condición de mujer y su condición de campesina. En ese sentido, se han desconocido derechos de propiedad de las mujeres que han sobrevivido a la guerra, en el marco del conflicto armado muchas han sido víctimas de violación y torturas de carácter sexual, han sido desplazadas y por el asesinato de sus cónyuges o la desaparición, el reclutamiento o el encarcelamiento han tenido que solventar las necesidades básicas en ambientes donde las condiciones materiales son pésimas.

El trabajo realizado por Nora Segura y Donny Merteens (1997) permite identificar facetas del desplazamiento violento en Colombia que hasta hoy no han tenido visibilidad ni reconocimiento. Al distinguir entre los desplazados a hombres y mujeres, adultos y menores de edad, surgen lazos y fuentes de tensión no perceptibles con otras perspectivas de análisis. Hay una trama de conflictos y presiones que desarticula los modos de vida y formas de organización de los hogares desplazados y acelera la descomposición de los estereotipos sexuales, las relaciones tradicionales entre los sexos y las generaciones, erosiona los soportes materiales y simbólicos de la preeminencia masculina y genera crisis en las identidades y en las relaciones afectivas y sociales.

Como se ha podido evidenciar en las cifras sobre desplazamiento, es sin lugar a duda un fenómeno que ha trastocado la vida en las esferas de la vida pública y privada, así como en caracteres de arraigo e identidad al territorio. El desplazamiento forzado se constituyó como un arma de guerra utilizada por gran parte de los actores vinculados al conflicto armado y pasó de ser a una consecuencia de la confrontación armada a una estrategia económica de usurpación de territorios. Sin lugar a duda, la mujer desplazada, víctima de la violencia, 
campesina sin tierra y sin derechos por el hecho de ser mujer rural, puede ser considerada como sujeta victimizada en múltiples dimensiones de la vida humana. En términos conceptuales, el desplazamiento forzado se asocia con diferencias sociales construidas en torno a la nacionalidad, etnoraciales y de clase. "Apenas recientemente se ha tomado conciencia sobre otros marcadores sociales de diferencia, como el género y la edad, que suponen formas peculiares de exposición a la violencia, consecuencias y posibilidades diversas en relación con la reconstrucción de proyectos de vida individuales y colectivos" (Segura y Merteens, 1997, p. 2).

En lo que respecta al género, la violencia puede abarcar desde experiencias intimas e individuales como la violencia sexual -frecuentemente usada sobre población femeninahasta contextos políticos y públicos de carácter colectivo en el marco de la guerra-con mayor tasa de implicación masculina directa-. No obstante, su diversidad de formas, contextos y significados, estas violencias comparten un elemento común: la destrucción (de bienes, de cuerpos, de identidades, de relaciones, de procesos sociales), aunque sus efectos corrosivos sean socialmente más reconocibles y reconocidos cuanto más distantes del espacio privado y de las relaciones domésticas. Así, en relación con el género, los imaginarios colectivos tienden a asociar la violencia pública-política con el mundo masculino, mientras que la violencia que involucra a la mujer se restringe al ámbito doméstico o, en contextos extradomésticos, casi exclusivamente al hostigamiento sexual (Segura y Merteens, 1997, p. 2).

Para el análisis de lo que significa ser mujer y campesina, en un contexto de violencia y desplazamiento, es necesario entender que el desplazado es, ante todo, víctima y sobreviviente. Y a pesar de que lleva tiempo enfrentando el drama de la desposesión, del desarraigo y del "no saber qué hacer o para dónde coger", se enfrenta indudablemente a un 
nuevo drama: reconstruir un nuevo modo de vida, un entorno social, un tejido colectivo y comunitario. De esta manera, la lógica desplazamiento-desarraigo-reconstrucción de la vida familiar y social requiere de "la reedición de un proyecto de vida en el sitio de llegada, las mujeres y los hombres deben hacerse cargo de su incierto futuro a partir de su múltiple condición social" (Segura y Merteens, 1997, p. 2).

Esta múltiple condición social, requiere necesariamente definir su causa: el desplazamiento forzado. Este fenómeno puede entenderse como la ruptura traumática espacial y temporal de los procesos sociales, económicos, familiares, políticos y domésticos a nivel micro, que se encontraban articulados a un tejido mucho más amplio: el sentido comunitario de la vida. El momento de ruptura genera procesos de desarraigo-violencia que vienen seguidos de procesos de búsqueda de nuevos lugares para vivir y reconstruir la vida, y en este proceso las diferencias de género son evidentes.

En el caso colombiano el desplazamiento violento de las zonas rurales opera a partir de un esquema sociocultural bastante agudo de separación de esferas masculina y femenina, de tal manera que para las mujeres se da en un marco vital centrado casi exclusivamente en las relaciones, el trabajo y la gestión domésticas, la maternidad, el espacio del hogar y desde luego una indudable sujeción al mandato del hombre. Las mujeres campesinas suelen tener una niñez, una adolescencia e incluso una vida de adulta caracterizadas por el aislamiento geográfico y social (Segura y Merteens, 1997, p. 8).

Una característica frecuente en los núcleos familiares rurales, es el hecho de que las relaciones con el trabajo remunerado, la información, "los límites con el mundo" están dados por los hombres y su rol de jefe del hogar. Primero fue el padre, luego el esposo y posteriormente serán los hijos. De esta manera, las mujeres campesinas se han visto relegadas 
al espacio micro que significa la casa, la propiedad o la finca. Así pues, el desplazamiento se ha configurado como un elemento en el que la mujer, sin capital social, encuentra un mayor sentimiento de desarraigo, a diferencia del hombre quien suele manejar un espacio social, geográfico y político más amplio.

A las mujeres campesinas colombianas se les puede considerar triplemente víctimas: primero por el trauma de los hechos violentos (asesinatos a familiares, cónyuge, hijos), segundo por la pérdida de los bienes de subsistencia (cultivos, casa, animales), lo que implica la ruptura simbólica y emocional con la cotidianidad conocida; tercero, el desarraigo social y el rechazo al llegar a un medio urbano de un contexto rural lejano. Así pues, se trata de una ruptura identitaria con el territorio expulsor de manera individual, colectiva y como sujetas políticas a quienes no se les han reconocido los derechos como campesinas y sobre sus tierras, que inician una etapa de restaurar el tejido social y familiar en ambientes hostiles y desconocidos.

En el marco de la restauración del tejido social, la participación política de las mujeres quienes han asumido el rol de víctimas, madres, esposas, desplazadas y campesinas ha sido relativamente poca. Para muchas viudas, adicional y simultáneamente a la pérdida del marido, se presentaron las amenazas, el estigma, la pérdida de bienes, y finalmente el desplazamiento, por razones ignoradas hasta entonces -actividades políticas que el esposo llevaba a cabo de manera pública o clandestina-. Por eso las mujeres desplazadas con frecuencia muestran resentimiento y hostilidad hacia las organizaciones y las actividades comunitarias, cívicas o políticas. Aunque dicha hostilidad puede darse en la mayoría de los casos, las experiencias de Barrancabermeja, Organización Femenina Popular (OFP), con una amplia tradición política y sindical, y de Montería, con una importante tradición de 
organización campesina (Segura y Merteens, 1997), se han consolidado en ejemplos de organización femenina que ha logrado una labor loable en términos de asociación y apoyo solidario como estrategia de supervivencia de mujeres desplazadas.

Vemos que la sociedad colombiana tiende a invisibilizar a la mujer en sectores sociales específicos con una situación social, política y económica poco o nada abordada a través de la formulación de políticas públicas de Estado, las mujeres campesinas han sido doblemente invisibilizadas. Sin embargo, no se trata solo de ocultar a los campesinos y campesinas en su carácter de ciudadano relegado de las zonas con presencia del estado, sino que es rechazada su importancia social y económica especialmente en la seguridad y soberanía alimentaria de Colombia.

Este hecho tiene la intención de impedir la presencia política del campesinado como sector político con unas apuestas en materia de tierras, economía campesina, ordenamiento territorial y medioambiental. Aunque la Constitución de 1991 reconoce y establece los derechos fundamentales de comunidades indígenas y negras, no se identificaron los derechos de los campesinos ${ }^{19}$. Esto ha significado no sólo el no reconocimiento en términos jurídicos y políticos, sino que también ha abierto escenarios de vulneración de derechos, desde el acceso a la tierra hasta la protección de la identidad campesina.

Como se puede ver en la siguiente gráfica, las mujeres rurales son el $47.14 \%$ de la población rural total. La Unidad de Producción Agropecuaria (UPA) en producción a cargo de mujeres supera las 400.000 y según el Registro Único de Víctimas, aproximadamente 4.064.710 mujeres fueron víctimas del conflicto armado colombiano.

\footnotetext{
${ }^{19}$ En diciembre de 2018 Colombia votó negativamente la Declaración de los derechos de los campesinos adelantada en la Asamblea General de la ONU.
} 


\section{Tabla 5. Datos poblacionales en las zonas rurales}

\begin{tabular}{|c|c|}
\hline Población total & 47802000 \\
\hline Hombres & $48,9 \%$ \\
\hline Mujeres & $51,1 \%$ \\
\hline Mujeres indigenas & $3 \%$ \\
\hline Mujeres afro, palenqueras y raizales & $10 \%$ \\
\hline Población rural & $23,4 \%$ \\
\hline Mujeres rurales & $47,14 \%$ \\
\hline Hombres rurales & $52,86 \%$ \\
\hline Hombres y mujeres victimas del conflicto armado según RUV & 8186896 \\
\hline Mujeres victimas del conflicto armado según RUV & 4064710 \\
\hline UPA $^{2}$ con responsables de la producción solo mujeres & 498886 \\
\hline UPA con responsables de la producción solo hombres & 1178715 \\
\hline UPA con responsables de la producción mujeres y hombres & 240993 \\
\hline $\begin{array}{r}\text { UPA con régimen de tenencia propia con responsables de la } \\
\text { producción solo mujeres }\end{array}$ & 363562 \\
\hline $\begin{array}{r}\text { UPA con régimen de tenencia propia con responsables de la } \\
\text { producción solo hombres }\end{array}$ & 849392 \\
\hline $\begin{array}{r}\text { UPA con régimen de tenencia propia con responsables de la } \\
\text { producción mujeres y hombres }\end{array}$ & 165140 \\
\hline $\begin{array}{r}\text { UPA con mujeres productoras residentes que declararon } \\
\text { tener maquinaria }\end{array}$ & 51642 \\
\hline $\begin{array}{r}\text { UPA con hombres productores residentes que declararon } \\
\text { tener maquinaria }\end{array}$ & 219934 \\
\hline $\begin{array}{r}\text { UPA con mujeres y hombres productores residentes que } \\
\text { declararon tener maquinaria }\end{array}$ & 67000 \\
\hline $\begin{array}{r}\text { UPA de mujeres productoras que recibieron asistencia técnica } \\
\text { en } 2013\end{array}$ & 65065 \\
\hline $\begin{array}{r}\text { UPA de hombres productores que recibieron asistencia } \\
\text { técnica en } 2013\end{array}$ & 216861 \\
\hline $\begin{array}{r}\text { UPA de mujeres y hombres productores que recibieron } \\
\text { asistencia técnica en } 2013\end{array}$ & 59704 \\
\hline $\begin{array}{l}\text { Porcentaje de mujeres mayores de } 15 \text { años residentes en } \\
\text { zona rural dispersa que manifiestan no saber leer ni escribir }\end{array}$ & $12,8 \%$ \\
\hline $\begin{array}{l}\text { Porcentaje de las mujeres mayores de } 15 \text { afios que se } \\
\text { autoreconocen como indigenas, que no saben leer ni escribir }\end{array}$ & $25,8 \%$ \\
\hline $\begin{array}{r}\text { Porcentaje de las mujeres mayores de } 15 \text { afios que se } \\
\text { autoreconocen como negras, afrocolombianas y palenqueras, } \\
\text { que no saben leer ni escribir }\end{array}$ & $14,9 \%$ \\
\hline $\begin{array}{l}\text { Porcentaje de las mujeres mayores de } 15 \text { años que se } \\
\text { autoreconocen como raizales, que no saben leer ni escribir }\end{array}$ & $6,6 \%$ \\
\hline
\end{tabular}


Fuente: Mujeres rurales en Colombia. 2017.

Las mujeres rurales han sido sustancialmente relegadas de programas y proyectos productivos, así como de titulación de predios y de asistencia técnica. A diferencia de los 219.934 hombres que declararon tener máquina en su UPA, sólo 51.462 mujeres declararon tener máquina. Las mujeres que declararon régimen de tenencia propia de su UPA fueron 363.562, mientras que los hombres que declararon régimen de tenencia propia de su UPA fueron casi un millón. Las diferencias, sin lugar a duda, son preocupantes no sólo en tanto la labor de la mujer campesina y el reconocimiento de sus derechos como campesina y productora no han sido reconocidos, sino que su condición de mujer en un contexto de violencia y machismo a distintos niveles -en muchos casos víctima del conflicto- no se ha reconocido. Además de esto, "en la ruralidad profunda también están las mujeres llevadas a la frontera agrícola como colonizadoras mestizas ante el despojo de tierras y desplazamiento. Son diversas realidades de mujeres que encuentran en común una serie de obstáculos en el acceso a la tierra y en el goce efectivo de los derechos humanos" (Lancheros, 2017, p. 5).

De acuerdo con el Tercer Censo Nacional Agropecuario desarrollado por el Departamento Administrativo Nacional de Estadística (DANE) en el 2014, en Colombia hay 2,4 millones de UPA. De los 43 millones de hectáreas de la totalidad del área rural, 34,4 millones de hectáreas son pastos, 7 millones de hectáreas están destinadas a agroindustria (caña, forestales, palma, café) ${ }^{20}$ y en la zona rural hay 21.5 millones cabezas de ganado (DANE, 2014).

\footnotetext{
${ }^{20}$ Esto evidencia un enfoque en el sector primario de la producción con especial interés en la producción de biocombustibles.
} 
El censo evidencia de igual manera, que existe una tendencia creciente de desigualdad estructural en factores como acceso a tierras, a programas de desarrollo rural integral y de acceso a tecnificación por parte de las mujeres campesinas. De hecho, las productoras tienen UPAs de menor tamaño, a diferencia del tamaño de las UPAs trabajadas o en propiedad de campesinos: "del total de UPA con solo mujeres productoras, el 78,4 \% tienen menos de 5 ha, y ocupan el 9,5\% del área" (Lancheros, 2017, p. 5). De igual manera, las mujeres campesinas tienen menores ingresos, la pobreza en población rural con hogares de jefatura femenina es 6.7 puntos mayor al promedio masculino. En la misma tendencia se ubica la participación laboral femenina (54\%): está 20 puntos porcentuales debajo de la participación laboral masculina (75\%) (DANE, 2014). Así pues, la participación de las mujeres en actividades no pagadas es del 93\% mientras que la participación de los hombres llega al 60\%.

Respecto a las desigualdades en términos económicos resaltadas por el Censo, Carmen Diana Deere (2012) afirmaba antes en su análisis de la situación de las mujeres rurales en América Latina que el empoderamiento económico de las mujeres no es el único camino hacia el empoderamiento, ni representa necesariamente el más importante en todos los contextos. No obstante, el económico suele ser crucial para el análisis del bienestar de la mujer por el énfasis que este concepto pone en la capacidad de las mujeres de poder elegir entre distintas alternativas, tomar decisiones y determinar e influir en los resultados para ella y/o su familia (Deere, 2012, p. 92).

Respecto a las cifras señaladas en términos de acceso a tierra por el Censo, Agarwal (2004) afirma anteriormente que, para las mujeres rurales, el acceso a la tierra tiene una posición privilegiada en comparación con hacer parte del mercado laboral, pues la propiedad otorga la posibilidad de enfrentar la desigualdad de género desde diferentes dimensiones. 
Además, el hecho de ser propietaria de su predio le permite generar nuevas relaciones sociales y nuevas formas de producción del espacio. De hecho, Deere y León (2002) señalan que las mujeres rurales en América Latina cuentan con posibilidades bastante limitadas para hacer parte del mercado laboral, lo que disminuye la calidad y condición de la vida y las somete a relaciones de poder y dominación en ambientes laborales que, en su mayoría, son urbanos.

La propiedad de la tierra por parte de la mujer, además de generar nuevas formas de relación social y de producción del espacio puede permitir promover lazos de asociatividad con otros/as propietarias. De igual manera, poseer una parcela, una UPA, o un fundo abre muchas más posibilidades para adquirir créditos, asistencia técnica y canales de comercialización a los que un productor sin tierra no podría acceder. “Aunado a ello, el contar con la propiedad de la tierra puede condicionar la participación de la mujer en organizaciones campesinas o comunales y también estar ligado a su identidad y reconocimiento social" (Ramírez Carpio, 2010 en: Deere, 2012, p. 94).

Al respecto, Cadavid Rico destaca que:

...el difícil acceso a las tierras es otra de las problemáticas más evidentes en cuestión de género. Pocas mujeres reconocen su derecho sobre éstas. La división de las labores del hogar las excluyó de la propiedad de la tierra y de su trabajo. Así, en la ciudad, debido a la ausencia masculina, al temor de ser amenazadas y agredidas nuevamente y al desconocimiento de las diligencias administrativas, las madres, hijas, hermanas o viudas renuncian al derecho de reclamar sus tierras. Quienes se atreven a hacerlo se ven envueltas en procedimientos burocráticos, son amenazadas por los grupos 
armados despojadores o se encuentran con que sus propiedades tienen nuevos dueños (Cadavid Rico, 2014, p.306).

El informe titulado La tierra en disputa. Memorias del despojo y resistencias campesinas en la costa Caribe 1960-2010 elaborado por el CNMH (2014) recopila historias de la organización campesina en los departamentos de Córdoba, Sucre, y la Región de los Montes de María (Departamento de Bolívar). En dicho aporte, se identifica la transición en términos de participación política de las mujeres campesinas, quienes iniciaron ejerciendo papeles de atención de primero auxilios a quienes sufrían las embestidas del ejército y la policía durante las jornadas de tomas de tierras, hasta que se logran consolidar como una parte importante del movimiento campesino con influencia y toma de decisión dentro de las estructuras políticas y en la vida social y comunitaria.

Este ocultamiento de las voces femeninas dado inicialmente dentro de organizaciones campesinas cuya mayoría eran hombres, puede entenderse por varias razones: 1 . No son propietarias de una parcela o de un fundo, lo que en términos prácticos no permite que se les reconozca su calidad de asociada propietaria. 2. Un "régimen de género" (CNMH, 2014, p. 293) que excluye a las mujeres de las posibilidades y recursos para que puedan tomar decisiones. 3. Las formas y normas de relacionamiento en ámbitos rurales han destinado a la mujer roles domésticos, limitando así las esferas de la vida pública y privada.

Aunque en los departamentos mencionados anteriormente, se destacan algunas lideresas mencionadas en la breve historia del movimiento campesino en el país, Juana Julia Guzmán, por ejemplo, y Felicita Campos, son sin lugar a duda dos mujeres que marcaron la lucha femenina con un componente de clase muy marcado. A diferencia de las mujeres de la élite -quienes recolectaban dinero a través de organizaciones de beneficencia y comenzaron 
a manejar redes de clientelismo- las mujeres de la clase trabajadora de la incipiente industria tabacalera y de textiles unificaron luchas con los comités veredales de la ANUC. De hecho, Juana Julia fue amenazada y perseguida por su acompañamiento a los comités veredales femeninos de la ANUC hasta su muerte en 1975.

Aunque los comités veredales de la ANUC significaron un primer paso en el desenvolvimiento político de las mujeres a nivel regional y nacional, las instituciones no las reconocían ni en las políticas agrarias de entonces, ni en las dinámicas y procesos sociales relacionados con el acceso a la tierra. Por ejemplo, la ley 135 de 1961 de Reforma Agraria, reafirmaba que sólo los hombres podían administrar el patrimonio. Así, a finales de los 80 sólo el " $11.2 \%$ de las adjudicaciones estaba a nombre de mujeres. Sin embargo, con sus procesos organizativos las mujeres campesinas fueron trascendiendo lo doméstico y rompiendo imaginarios que de ellas se tenía” (CNMH, 2014, p. 301).

Al igual que las instituciones y políticas, las organizaciones tenían un fuerte régimen de género que impedía la continuidad femenina en los procesos políticos, jurídicos y sociales. Aunque no hay que desconocer que se identificaba a la mujer campesina como compañera de lucha, no era tenida en cuenta en coyunturas como la negociación con el Instituto Colombiano de Reforma Agraria (INCORA), "alegando que ellas no estaban suficientemente preparadas para ello" (CNMH, 2014, p 302).

A pesar de este régimen de género, las mujeres campesinas de los 70 y 80 eran participantes activas de las tomas de tierras y en la defensa contra las agresiones de la policía, además eran las encargadas de identificar y buscar a quienes hubieran sido detenidos en el marco de dichas acciones -la semilla de los comités de derechos humanos de las organizaciones-. Con el paso del tiempo, a raíz de la crítica y autocrítica de las mujeres 
dentro de muchas organizaciones, así como el contexto a nivel nacional y global, se empezaron a difundir con mucha más fuerza nociones acerca del verdadero papel de la mujer en la organización social en contra de la violencia, el acaparamiento de tierras, el desplazamiento y el acceso a créditos, tecnificación y titulación de los predios y parcelas.

Aunque el desenvolvimiento organizativo de las mujeres ha significado el fortalecimiento de procesos de empoderamiento del rol de las campesinas en la vida social y política, quienes se atrevieron a reivindicar el derecho de voz y voto dentro de las organizaciones campesinas, tuvieron que enfrentarse a los retos culturales de su contexto.

Fueron altos los costos que debieron asumir por cuestionar los regímenes de género y lograr que las mujeres campesinas también fueran interlocutoras válidas en los procesos agrarios. Sin embargo, con su presencia lograron entre los años ochenta y noventa pasar de "mujeres de tropel" a mujeres productoras y "a mandar la parada" alrededor del sostenimiento de la organización campesina, en medio del proceso de debilitamiento de la ANUC (CNMH, 2014, p. 337).

Durante los años noventa e inicios de los dos mil, las comunidades campesinas vivieron un proceso de violencia exacerbada a raíz de la incursión de nuevos actores armados y la proliferación de intereses políticos y económicos que utilizaron la violencia para apropiarse de tierras e instaurar proyectos productivos como la palma en grandes extensiones. Líderes y miembros de las bases fueron asesinados y muchos de ellos despojados. El carácter de campesino se rompió y quienes algún día lucharon bajo el lema “tierra pa’l que la trabaja” se convirtieron en individuos sobreviviendo en las grandes urbes, en ambientes hostiles y bajo la mirada de una institucionalidad que poco o nada se interesó en resolver su condición de desplazados. 
Dicha condición, especialmente en las mujeres, se produce no sólo a raíz de los asesinatos, las masacres, los combates y las intimidaciones, sino que es el resultado de una exacerbada violencia sexual, estrategia utilizada como parte de la cadena de despojo para demostrar poder absoluto sobre el cuerpo y el territorio. Sin embargo, la violencia sexual no se ha dado en el mismo momento de despojo, sino más bien, como un primer paso en el largo proceso de intimidación que termina en el despojo y desplazamiento.

Como lo menciona Cadavid Rico:

...en cada caso de mujeres en situación de desplazamiento hay una historia de violencia sistemática que culmina en el desalojo de tierras. Enfrentarse a la necesidad de asumir la responsabilidad económica de la familia llevada tradicionalmente por el hombre las sumerge en una vida llena de incertidumbres. Esto, sumado a la baja escolarización, al desconocimiento de los derechos y a la sobreestimación de la vida por encima de la dignidad, genera una espiral de impunidad que evita la denuncia por considerarse afortunadas de no morir (Cadavid Rico, 2014, p. 304).

Analizar la emergencia de las políticas públicas en lo que concierne a la mujer rural exige remontarse hacia inicios de la década de 1920 donde la influencia de personajes femeninos de la clase trabajadora se tomaban las plazas públicas y arengaban contra la situación actual de los obreros del país y desafiaban el orden socialmente establecido con un claro referente machista. Desde luego, personajes como María Cano y Juana Julia Guzmán serían determinantes para el fortalecimiento de la senda de las reivindicaciones por tierra, pan y libertad, pero para la mujer rural esto significaba aún más. 
Las primeras incursiones de la mujer rural colombiana del siglo XX en cuestiones de liderazgo del movimiento campesino inician hacia mediados de 1921 con la lucha por la eliminación de la herencia colonial que sometía a los campesinos sin tierra y a los descendientes de los esclavos africanos. La fuerte emergencia del movimiento campesino en la región del Caribe Colombiano con la forma de explotación cooperativa de las tierras denominada Los Baluartes, significó además una pugna por el control territorial que se disputaba a compañías extranjeras que actuaban sin ningún control en contra de los derechos de los trabajadores que vivían en condiciones de miseria en las plantaciones de tabaco y banano.

Aunque fueran ideas moderadas, eran demasiado amenazantes para los latifundistas, de modo que comenzó contra los baluartes un enfrentamiento sin medida. Campesinas y campesinos lograron demostrar con certificaciones del Ministerio de Agricultura que todos esos terrenos eran baldíos nacionales $\mathrm{y}$, sin embargo, algunos terratenientes comenzaron a reclamarlos como propios. La estrategia para derrotar a los campesinos fue entonces la conspiración que en el Baluarte Rojo terminó también en una matanza de campesinos (Fals Borda, 1986, p.147A).

Una de las lideresas campesinas más recordadas de esta emergencia del movimiento agrario en el norte de Colombia es Juana Julia Guzmán quien nació en 1892 en Córdoba y vivió 83 años. Lideresa campesina y socialista, fue cofundadora del Baluarte Rojo de Lomagrande (1916) y de la Sociedad de Obreros y Artesanos de Córdoba (1918); impulsó la creación de la Sociedad de Obreras Redención de la Mujer (1919), colectivo integrado por bailadoras de fandango, lavanderas, fritangueras, vendedoras y cocineras (Díaz Suasa, 2002, p. 4). 
Juana Julia vivió entre persecuciones y tomas de tierras en Córdoba y Sucre, hasta que en 1951 la policía la apresó e intentó quemarla viva en Lomagrande "[...] me sacaron del cepo con dos compañeros más (Julián Díaz y Zenón Bonilla) y nos embarcaron para Montería, dicen que por no matarme en el mismo Lomagrande... Un teniente Torralvo mandó a un civil a buscar una lata de gasolina para echármela a los pies y prenderme viva" (Colectiva Juana Julia Guzmán,). Esto evidencia que la persecución política ha significado una herramienta efectiva para el proceso de acumulación por desposesión (Harvey, 2005) y el fortalecimiento del gamonalismo.

Mientras tanto, al sur del país en los territorios indígenas de Cauca, Tolima y Huila el movimiento liderado por el indio Quintín Lame tomaba fuerza, y sus reivindicaciones por el derecho al acceso a la tierra se expandían por Cundinamarca y la provincia del Sumapaz. De hecho, hacia 1912 el movimiento campesino en Sumapaz inicia sus primeras acciones directas bajo el mando de Eufrosina Molina, que tenían como objetivo ocupar las tierras que los latifundistas se apropiaban y titulaban sin haberlas ocupado nunca (Mondragón, 2002).

Catorce mil mujeres del movimiento indígena liderado por el legendario Quintín Lame, también socialista, firmaron en 1927 el Manifiesto sobre Los Derechos de la Mujer Indígena en Colombia. La matanza de 9 indígenas de Castilletes, Guajira, desbordó la indignación y con una gran fuerza se reivindicaron los derechos de las mujeres frente a los hombres blancos y se integraron a los derechos étnicos y de clase (Díaz Suasa, 2002, p. 6). De esta manera, no sólo el proceso histórico ampliamente estudiado por Mariátegui (1928), Donny Meertens y Gonzalo Sánchez (1983) denominado gamonalismo, iba tomando forma como proceso de dominación a partir de la herencia colonial-feudal y la acumulación de una de las tres fuentes de la riqueza; sino que la mujer campesina y en general el movimiento 
campesino empezaría a definir su horizonte político, que tenía como principal objetivo la reforma agraria y consolidar derechos de propiedad. La ley 200 de tierras, como fue mencionada en el capítulo II, significó un ejercicio primordial de garantía de derechos de propiedad y de regulación de la estructura tenencia de la tierra.

En la ley 200 se plasmaron elementos de trascendencia para el sector agropecuario. Dos de ellos fueron:

1. La creación de la Jurisdicción Agraria con la existencia de jueces especializados en dirimir conflictos de tierras.

2. La introducción de la figura de la Extinción del Dominio o pérdida de la propiedad como resultado del incumplimiento de su función social, cuando el propietario deja sin explotación económica la tierra durante un lapso determinado (Mondragón, 2002, p. 27).

Las Ligas Campesinas y los sindicatos agrarios comenzaban a apoderarse del escenario político y sus reivindicaciones comenzarían a ser escuchadas con unas de las primeras políticas agrarias enfocadas a estrechar la brecha de desigualdad rural: la ley 74 de 1926 que establecía la necesidad de crear el Instituto Agrícola Nacional y a su vez, implementar en los procesos escolares el fortalecimiento de mallas curriculares direccionadas hacia la vocación agropecuaria.

A su vez, la ley 74 decretaba la obligación del Ministerio de Industrias para ofrecer una cantidad determinada de tierras para la colonización, una especie de incipiente colonización dirigida -que se volverá a ver con el poblamiento de los territorios nacionales del oriente del país-, con el fin de entregar lotes divididos en un área de no más de cien mil hectáreas. Cada uno de estos lotes no debería sobrepasar las ochenta hectáreas. Esta fue una 
de las primeras experiencias de política pública relacionada con una reforma agraria. Sin embargo, es importante mencionar que esta ley aún no contemplaba a la mujer rural desde la institucionalidad como sujeta política de derechos.

No sería sino hasta 1932 que se lograría la "libre administración y disposición de los bienes de cada uno de los cónyuges y otorgó a la mujer casada la facultad de comparecer libremente en juicio" (Velásquez, 1986, pp. 197-198). A pesar de esto, los liderazgos femeninos en el movimiento campesino de la primera mitad del siglo XX continuarían gestándose silenciosamente en todo el país. De hecho, la herencia de este proceso organizativo se vería evidenciada en los levantamientos populares que tuvieron lugar en Colombia durante el 2013 y 2014 (ver mapa 1).

Con la Ley 200 un nuevo concepto entraría a ser pieza clave en la estructura de la tenencia de la tierra y en general, de la estructura agraria del país: la función social de la propiedad. En pocas palabras, la función social de la propiedad consistía en demostrar que la tierra se estaba utilizando para beneficiar a la economía local, regional y nacional, es decir, que se estaba trabajando. Nuevamente recobra fuerza el lema de "tierra pa'l que la trabaja" y se plantea, otra vez, la necesidad de eliminar las relaciones coloniales. Como respuesta, los terratenientes fundan la Acción Patriótica Económica Nacional -APEN- en 1935, una organización reaccionaria de origen conservador y liberal radical que veía en las apuestas de López Pumarejo una "amenaza comunista". 


\section{Mapa 4. Movilización campesina en Colombia.}

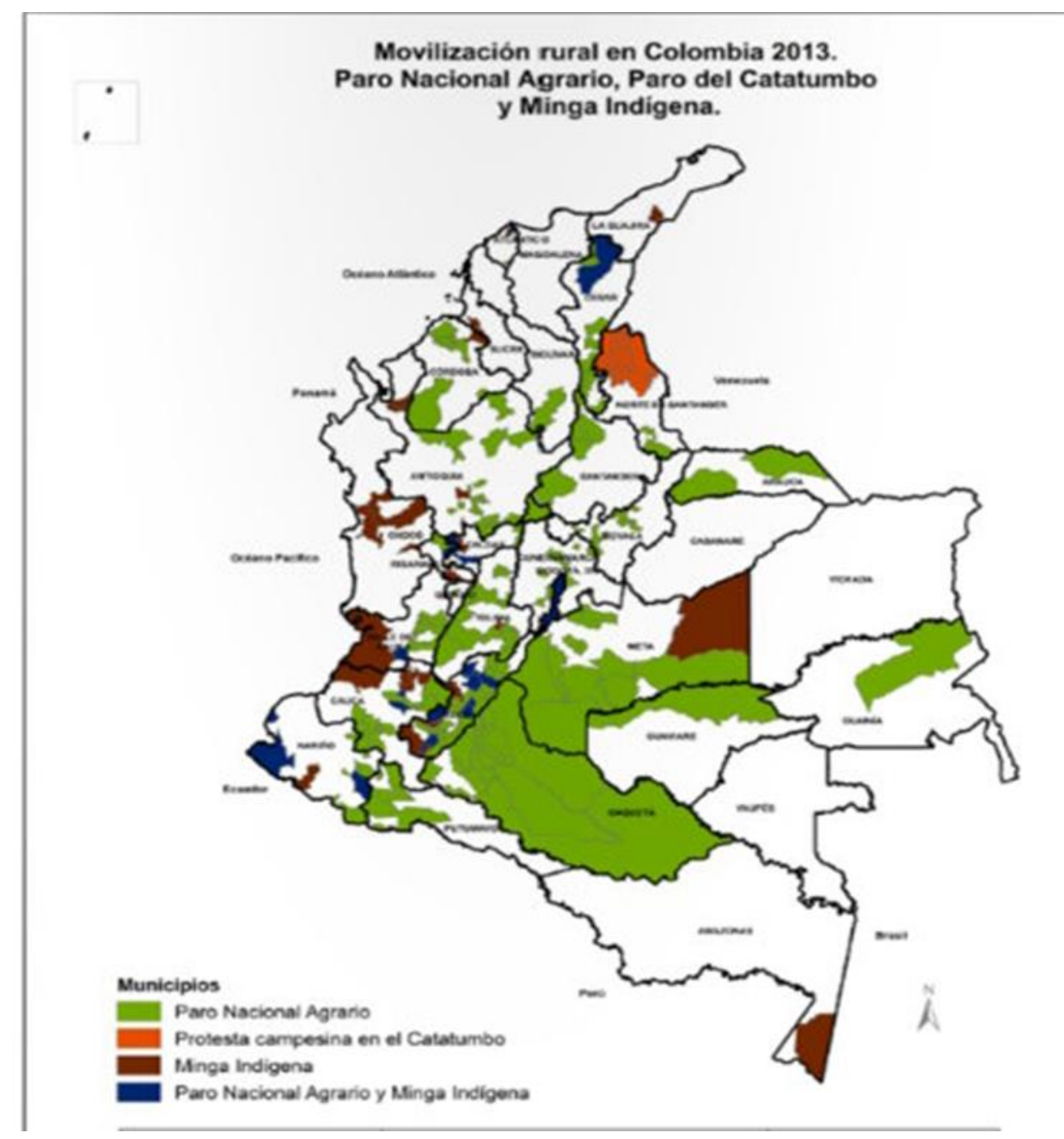

Fuente: Semanario Voz. 2013.

Para 1948, el asesinato de Jorge Eliécer Gaitán desencadena una serie de disputas violentas entre miembros de los dos partidos tradicionales: liberales y conservadores. Esta situación nuevamente impulsa los flujos migratorios de campesinos, especialmente liberales, desde el centro del país hacia el oriente y sur oriente. Años más tarde, la profundización de la violencia y el resquebrajamiento de las instituciones “democráticas” en el país, darían paso a la conformación de autodefensas liberales. Muchos de estos grupos dejarían las armas con 
la paz prometida por Gustavo Rojas Pinilla, pero muchos otros, desconfiados y seguros de que serían traicionados, fundan el Bloque Sur, que en 1964 se convertiría en las Fuerzas Armadas Revolucionarias de Colombia (FARC).

El gobierno de Valencia optó por desechar la reforma agraria y en cambio, en mayo de 1964, ordenó atacar a los antiguos guerrilleros campesinos en Marquetalia (Tolima), de manera que se desató de nuevo el conflicto guerrillero. La aplicación de la ley 135 se aplazó en la práctica hasta el período presidencial siguiente, el de Carlos Lleras Restrepo (19661970). Lleras impulsó la ley y consideró necesaria la organización nacional del campesinado, para que hubiera, aunque fuera una mínima reforma agraria (Mondragón, 2002, p. 33).

Con la puesta en marcha de la Ley 135, nuevamente los terratenientes, herederos de los valores coloniales sobre la tierra se unifican y en 1972 firman el Pacto de Chicoral. La Ley 135 tenía la característica de ser reformista, no contemplaba las expropiaciones como una fuente de tierras. Por el contrario, el INCORA era la institución encargada de comprar los predios y así poder hacer una distribución más justa. El Pacto de Chicoral básicamente elevó los precios de los predios que estaban en lista de compra por parte del gobierno nacional, haciendo imposible su adquisición. Esta jugada terrateniente y gamonal, se plasmó en la Ley 4 de 1973.

Durante la década de los años setenta y ochenta, en medio de una fuerte arremetida violenta por parte del gobierno nacional en las zonas rurales para contrarrestar el fortalecimiento de los grupos insurgentes recién creados, la organización campesina se vio seriamente afectada por las diferentes declaraciones que los estigmatizaban como auxiliadores del comunismo internacional. La doctrina del enemigo interno y la Doctrina Yarborough, inspirada por el norteamericano William Pelham Yarborouth, la cual consiste 
en el entrenamiento de personas para que se enfrenten a ciudadanos con ideas políticas diferentes, llegan a Colombia en el año 1962 para instaurar un entrenamiento de soldados para la guerra. En un suplemento ultra secreto de su informe al Estado Mayor Conjunto de Estados Unidos, instó a crear una fuerza irregular para que actuara inmediatamente con el propósito de eliminar comunistas, porque consideraba que los comunistas representaban una latente amenaza en el futuro.

Esto significarían un aumento considerable de hechos violentos contra campesinos y campesinas que vivían en zonas de influencia de las guerrillas. Desde luego, en este punto la mujer campesina retoma su papel protagónico en las labores del hogar, la crianza y el sostenimiento económico, pues la mayoría de hombres fueron asesinados o hacían parte del conflicto social y armado que se acaecía en ese entonces.

Con la consolidación de la APEN, en 1944 se consigue la aprobación de la Ley 100 de ese mismo año. Esta consistía principalmente en declarar de conveniencia pública los contratos por aparcería. La aparcería consiste en la explotación de pequeñas parcelas a cargo de familias de campesinos sin tierra, quienes deben no sólo trabajar para ganar su sustento, sino para pagar la "benevolencia" del latifundista por dejarles trabajar su tierra. Ramírez Bacca diría sobre la aparcería que "la hacienda es considerada no como una unidad de producción sino como un conjunto de pequeñas parcelas, explotadas individualmente por familias de aparceros, cuya propiedad pertenece a un dueño común” (2010, p. 19).

En este contexto nace la Asociación Nacional de Usuarios Campesinos:

El Estado creó la ANUC mediante decreto 755 en 1967 para ayudar a impulsar la política de la Reforma Agraria. Luego de un rápido crecimiento (alcanzó un millón 
de inscritos) y del gran auge en la lucha campesina llegó la primera gran división en 1972, critica para el movimiento campesino porque se fraccionó en dos grupos asimétricos y antagónicos: la 'línea armenia', a donde fueron 10 mil afiliados, contaba con protección estatal, y la 'línea Sincelejo', a la que llegaron 300 mil afiliados y era independiente del Estado. Entre las dos 'líneas' no alcanzaron a reunir ni medio millón de los afiliados que tenía la ANUC original (Múnera, 1997, p. 154).

La línea Sincelejo, reconocida como la ANUC-Unidad y Reconstrucción (UR), aprovechó la independencia de su organización y la cantidad de sus miembros para dar inicio a las nuevas luchas en el marco de la doctrina del enemigo interno y de la lucha anticomunista. En 1972 las mujeres campesinas de la ANUC empiezan a tener un papel protagónico dentro de la dinámica organizativa, y a pesar de que la creación del Frente Femenino no se concretó, los encuentros de mujeres hacia 1977 sumado a la diversificación de miembros de la ANUC significaron nuevos escenarios en donde las campesinas tuvieron un rol preponderante.

Como lo menciona Pérez Ortega (2010) en su libro Luchas campesinas y reforma agraria, fue en el departamento de Sucre donde se desarrollaron con mayor intensidad las acciones colectivas con miras a la toma de tierras y al reconocimiento del campesinado como sujeto político y de derechos. De hecho, Pérez (2010) resalta que, en sólo siete años, la ANUC logró recuperar más de 55.000 hectáreas para campesinos sin tierra, y una cantidad considerable de dinero en créditos utilizados para fortalecer la economía y la vida campesina.

Esta participación fue confirmada en el Encuentro Nacional de Mujeres Campesinas realizado en Ovejas (Sucre) del 16 al 17 de marzo de 1974. A esta reunión asistieron más de 
trescientas delegadas de todo el país, y se destacó su espíritu combativo y su nivel de conocimientos políticos. Además de este tipo de eventos, la mujer campesina sucreña demostró su capacidad de decisión para la lucha en las marchas rurales de San Pedro y la Mojana sucreña, que se realizaron para presionar y lograr la captura de los “pájaros”, matones a sueldo que los propietarios de tierras contrataron (Pérez, 2010, p. 140).

De igual manera, las mujeres miembros de la ANUC en la región norte del país participaban activamente de las acciones directas que tenían como objetivo las tomas de oficinas y sedes gubernamentales de instituciones como el INCORA, la Gobernación de Sucre y la iglesia principal de Sincelejo. Sin embargo, es importante resaltar que la mujer campesina en esta etapa de luchas agrarias se consolidó como un actor importante que sumaba esfuerzos para las acciones directas, pues en lo que respecta a los elementos de la toma de decisión, tuvieron que sortear elementos propios de la estructura machista dentro de la organización campesina. De hecho, muchas de las conclusiones de los talleres y encuentros regionales y nacionales en muchas ocasiones no recogían las propuestas y exigencias de las campesinas y pasaban a segundo plano.

A pesar de que en el plano nacional y en lo que respecta al Comité Ejecutivo nunca en su seno ha estado una mujer, en la junta directiva nacional no se puede dejar de reconocer el destacado papel de las compañeras Ana Carmen Cortés de La Guajira, Margarita Salcedo de Norte de Santander, Margarita de Valderrama de Cundinamarca, Ana Félix de Villalva del Valle del Cauca y activistas políticas como María Victoria Reyes y Emperatriz Santander, entre otras (Pérez, 2010, p. 142). 


\section{Imagen 2. Acto político de la ANUC}

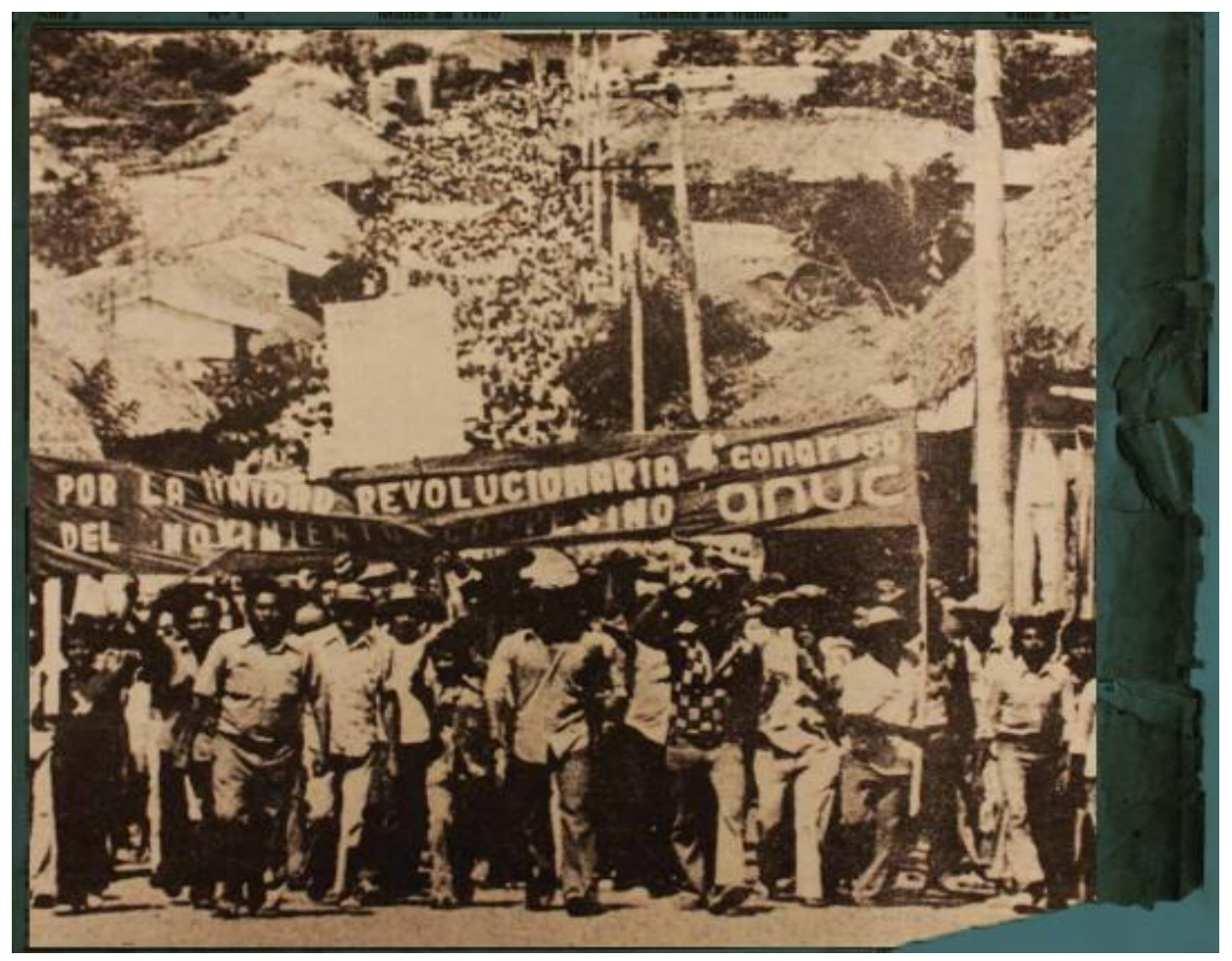

Fuente: Jesús María Pérez Ortega, 2010

Además de la ANUC, como ya se explicitó, en la década de los sesenta y setenta nace la Federación Nacional Sindical Unitaria Agropecuaria -FENSUAGRO-. Es importante mencionar que el nombre fundacional de la organización fue Federación Nacional Sindical Agropecuaria (FENSA). "Dentro del grupo de apoyo de aquel partido destacaron varios dirigentes campesinos como Raúl Herrera, Saúl Zambrano, Gerardo González y Luis Eduardo Sabogal” (Castaño González, 2019, p. 182).

Es importante resaltar que las luchas políticas de la generalidad de las organizaciones campesinas en Colombia, ha estado atravesada por el reconocimiento del campesinado como sujeto de derechos. Desde luego, ha sido una férrea defensa de la economía campesina, así como de la Reforma Agraria y más recientemente de la Reforma Rural Integral. En ese 
sentido, la base campesina de la ANUC, FENSUAGRO y demás organizaciones agrarias y rurales, han definido en su horizonte político una lucha frontal contra el capitalismo en su fase neoliberal.

Así pues, el rechazo de la ampliación de la agroindustria y el apoyo monetario y político para cultivos que no son de consumo humano, la inequitativa estructura de la tenencia de la tierra, los desplazamientos forzados y la utilización del aparato paramilitar para promover la acumulación por desposesión (Harvey, 2005) son banderas de la organización campesina. De igual manera, la defensa de las Zonas de Reserva Campesina (ZRC) como figuras del ordenamiento territorial, el enfoque diferencial y de género, la titulación individual y colectiva a los campesinos sin tierra o poca tierra, la defensa de la economía campesina, la seguridad y la soberanía alimentaria, son elementos cruciales para analizar el accionar político de los sindicatos agrarios en Colombia.

\subsection{Condiciones jurídicas en Colombia para la mujer rural}

El debate teórico-práctico acerca de lo rural y lo campesino ha estado presente en numerosos escritos y reflexiones académicas. Desde luego, la noción de ser mujer rural o campesina necesariamente refiere a la propiedad, subjetividades, imaginarios, relaciones y cargas simbólicas reflejadas en el entorno, especialmente la tierra como fuente del trabajo en el campo. Es posible afirmar que a lo largo de la historia muchas campesinas -o mujeres rurales- han hecho una transición de colonas en búsqueda de nuevas tierras para cultivar y 
zonas alejadas de la violencia, hasta la transformación en campesinas que trabajan sus parcelas para pan coger.

Sin embargo, en el momento en que los procesos de ordenamiento territorial obligan al desplazamiento -como por ejemplo dentro de zonas de protección ambiental-, nuevas olas de violencia se ciñen sobre el territorio, generando nuevamente el ciclo de la desposesión. Quienes no tienen la posibilidad de huir a los centros urbanos en búsqueda de nuevas formas de sustento, lo único que les queda por vender es su fuerza de trabajo, y es allí donde la campesina queda atrás para dar paso a la asalariada rural, la trabajadora rural.

La estructura agraria en Colombia tradicionalmente se ha caracterizado por la desigualdad en la propiedad sobre la tierra y la persistencia de la gran propiedad latifundista, por un lado, y en la pequeña economía campesina por el otro. Esta tendencia se ha reforzado en los últimos años como resultado del despojo violento de las tierras de los campesinos y los territorios colectivos de las poblaciones afrocolombianas e indígenas por parte de las estructuras paramilitares al servicio de grandes terratenientes y empresarios. Asimismo, la concentración de la propiedad de la tierra ha sido decididamente estimulada por las políticas agrarias adoptadas en la última década (Comisión Colombiana de Juristas, 2011, p. 8).

En ese sentido, en Colombia las condiciones están dadas para hablar en unos casos de campesinas y en otros de trabajadoras rurales. El punto central, desde la perspectiva de este escrito, es el acceso a la propiedad. De hecho, la Organización de las Naciones Unidas para la Alimentación y la Agricultura, FAO (s.f) ha identificado nueve grandes categorías de mujeres rurales, sin embargo, para efectos de este estudio, las más importantes por su similitud con la realidad rural colombiana son: 
1- Productoras no intensivas, quienes no trabajan directamente la tierra, pero compran insumos y cuidan los cultivos de pancoger. La economía de los bienes, la que se considera "la economía propiamente dicha"; y, por otro lado, la economía oculta, invisible, la economía del cuidado. Lo que las diferencia es que el trabajo en la segunda no es remunerado, no se contabiliza y sobre todo es realizado principalmente por las mujeres, sin distinción de edad, raza o etnia (Campillo 1999, p. 97).

2- Productoras intensivas, quienes desarrollan las anteriores labores sumadas a las decisiones como jefa de explotación o familia. Esta es una categoría que en algunas situaciones puede evidenciarse. De acuerdo con lo mencionado en capítulos previos de esta tesis, la mayoría de mujeres quedaron viudas o han sufrido algún tipo de violencia en el marco del conflicto armado que las ha obligado a asumir diversos roles para mantener a la familia, incluso a pesar de ser desplazadas. El promedio nacional de hogares con jefatura femenina es del $25 \%$ y en el campo asciende al $27 \%$ y dentro de la población en situación de desplazamiento forzado las jefaturas femeninas se incrementan aceleradamente. Los hogares con jefatura femenina en comparación con los de jefatura masculina, en 1995, presentaban un mayor número de personas desocupadas $(4,7)$ y mayor número de personas a cargo $(3,7)$ (Díaz Suasa, 2002, p. $32)$.

3- Habitantes rurales, quienes no poseen tierras para cultivar, en su mayoría por cuenta del despojo violento, lo que las obliga a vender su fuerza de trabajo en la rama de los servicios. La proletarización de la mano de obra masculina ha obligado a muchas mujeres a responder solas por la parcela. Inclusive, algunas de ellas realizan otras labores en la casa para garantizar algún otro ingreso o salen a trabajar o a vender algo en condiciones progresivas de precarización. La situación es tan aguda que la pobreza 
afecta a más del $60 \%$ de las mujeres rurales, fenómeno conocido como feminización de la pobreza (Díaz Suasa, 2002, p. 30).

4- Asalariadas rurales temporales y permanentes, cuyos periodos de trabajo obedecen a las necesidades propias de la labor o propiedad en la que trabajen. Es indudable que la relación entre lo rural y lo campesino está ligada con la inserción en el capitalismo de las diferentes formas de asociatividad, de los mercados rurales, las formas de tenencia y de explotación. Lo campesino se ha caracterizado por la diversificación de la economía, ligada a una apropiación espacial que considera la parcela y la tierra como una extensión del ser. Una subjetividad simbólica donde los valores que se le dan a la finca, fundo u hato traspasan la lógica mercantil de lo rural.

La producción rural en la mayoría de los casos se encuentra dirigida hacia la competitividad internacional con monocultivos de productos que generen potenciales rendimientos. Las plantaciones de sorgo, soya, palma de aceite, caña de azúcar y maíz para etanol son la generalidad de la transformación de la ruralidad en Colombia y América Latina en el marco de la profundización del neoliberalismo.

La persistencia del conflicto armado interno, el desplazamiento forzado de la población rural y el abandono y/o despojo de sus tierras, al lado de las políticas de fomento de la producción agroindustrial que apoyan el modelo exportador de recursos naturales y el desmonte de las instituciones de la reforma agraria, no han contribuido a modificar la concentración de la propiedad de la tierra en el país (Comisión Colombiana de Juristas, 2011, p. 10). 
Esta situación sin lugar a dudas ha cambiado la estructura social y la mujer ha dejado de ser campesina para pasar a trabajadora rural. Un proceso de proletarización que mantiene los roles de género en muchos casos y la desigualdad en remuneración, cargas de trabajo doméstico no pago y la cultura rural que ha destinado exclusivamente a las labores del hogar a las mujeres y la poca participación en la toma de decisiones en cuanto la economía familiar.

Desde esta mirada, se privilegia la reflexión sobre la división sexual del trabajo, de gran pertinencia para analizar las labores que realizan las mujeres, en particular, las campesinas en la unidad de producción. Allí la producción y la reproducción están íntimamente ligadas y se crea un efecto de invisibilización sobre el trabajo realizado por las campesinas en las dos esferas (Díaz Susa, 2002, p. 37). A pesar de que se evidencia que la legislación rural se ha desarrollado en algunos momentos de la historia con el ahínco de solucionar problemas estructurales como el uso, ocupación y tenencia de la tierra, la experiencia demuestra que la mujer rural no era tenida en cuenta como un sujeto con características e individualidades propias.

Luego de todo un proceso de resistencia, violencia, desplazamientos, muertes y desolación provocados por causas estructurales y el uso de estrategias armadas y paramilitares, la institucionalidad se enfoca en 1994 con los primeros visos de política rural enfocada en la mujer. Mujeres que siendo viudas y madres deben asumir totalmente las riendas del hogar y la economía. Teniendo como referente la VI Conferencia Regional para la mujer rural realizada en Argentina, se aprobó el plan de acción regional para las mujeres de América Latina y el Caribe liderado por la FAO.

Este plan fue el que orientó las acciones de los gobiernos participantes (entre ellos Colombia), a fin de diseñar políticas y estrategias de desarrollo, que permitieran a los Estados 
respuestas más permanentes a las demandas diferenciadas de hombres y mujeres, eje central de las estrategias de desarrollo. Por tal motivo, este enfoque propuso áreas prioritarias de trabajo como: acceso a la tierra, tecnología, financiamiento rural, manejo de la biodiversidad, participación de la mujer en procesos de toma de decisiones, fortalecimiento de organizaciones campesinas, etc. En el marco de esta macro política surge en Colombia la “Política para el desarrollo de la mujer rural de 1994” (Muñoz, 2003, p. 101).

La transición de la figura de la mujer campesina a la mujer rural en la legislación y el marco normativo del país, permite comprender que existe una estrategia de inserción en el capitalismo de los habitantes de los campos colombianos, en especial de las mujeres quienes -como se ha mencionado en varias ocasiones- han sido afectadas por el conflicto armado en distintas esferas.

La ley 160 de 1994, cuya esencia era dar tierra a campesinos sin tierra, tomando los baldíos de la nación como propiedades susceptibles de adjudicación, fue inicialmente una esperanza para solucionar el problema agrario de la inequitativa estructura de la tenencia de la tierra. Sin embargo, los procesos de titulación se generaban a individuos o parejas que demostraran una serie de condiciones, lo que limitaba en muchos casos la adquisición de tierras por parte de cooperativas y asociaciones campesinas. "En algunos casos los grupos de mujeres han probado ser efectivos para desarrollar esquemas de producción cooperativa, pero al mismo tiempo se han visto rechazados cuando han solicitado manejo comunal de la tierra" (León y Deere, 1997, p. 16).

La ley 731 del 2002 establece la necesidad de otorgar beneficios a la mujer rural de bajos recursos, con el fin de lograr disminuir la brecha de desigualdad entre hombres y mujeres, y especialmente entre las mujeres rurales y el resto de la sociedad. Luego de la compleja 
experiencia de la limitación a la titulación colectiva de tierras de la Ley 160, esta ley elimina esa traba jurídica para promover la asociatividad y las empresas comunitarias de mujeres rurales, así como capacitaciones con el Servicio Nacional de Aprendizaje (SENA) con el fin de promover la tecnificación de los procesos.

Por otro lado, la ley 1257 del 2008 promueve la protección patrimonial de los bienes de las mujeres campesinas. Un elemento interesante es que a diferencia de la ley 731 del 2002, en esta sí se hace mención a mujer campesina. Esto se debe a que la esencia de la ley es proteger la propiedad de la mujer campesina, blindarla y garantizar acciones efectivas de reparación. Una vez más, el elemento de la propiedad permite comprender la diferenciación entre ser mujer rural y mujer campesina.

La ley 1448 del 2011, mejor conocida como Ley de Víctimas establece un punto fundamental en la transformación del enfoque jurídico: la necesidad de abordar los casos con una visión diferencial y de género. Por lo tanto, la ley establece que el Estado ofrecerá especiales garantías y medidas de protección a los grupos expuestos a mayor riesgo de las violaciones tales como mujeres, jóvenes, niños y niñas, adultos mayores, personas en situación de discapacidad, población campesina, líderes sociales, sindicalistas, defensores de derechos humanos y víctimas de desplazamiento forzado (Comisión Colombiana de Juristas, 2011, p. 27).

A su vez, la Ley de Víctimas establece trato preferencial y reducción de trámites para la restitución de tierras solicitada por mujeres víctimas del conflicto armado y de desplazamiento forzado, así como estrategias para favorecer el acceso de las organizaciones o redes de mujeres a procesos de reparación (artículo 114). “Asimismo, la ley 1148 otorga 
prioridad a las mujeres a quienes se les restituya la tierra en la aplicación de los beneficios de la ley 731 de 2002” (Comisión Colombiana de Juristas, 2011, p. 28).

El proceso de paz de La Habana desarrollado entre las FARC-EP y el Gobierno de Colombia retoma la necesidad imperante de garantizar el acceso a la propiedad, la tecnificación y los recursos necesarios para fomentar y dinamizar la economía campesina, especialmente la desarrollada por mujeres rurales y madres cabeza de familia. En el documento se establece que uno de los elementos centrales para una verdadera transformación estructural del campo requiere de medidas y estrategias dirigidas a promover el uso adecuado de la tierra de acuerdo con su vocación y estimular la formalización, restitución y distribución equitativa de la misma, garantizando el acceso progresivo a la propiedad rural de quienes habitan el campo y en particular a las mujeres rurales y la población más vulnerable, regularizando y democratizando la propiedad y promoviendo la desconcentración de la tierra, en cumplimiento de su función social (FARC-EP y Gobierno de Colombia, 2016, p. 10).

Nuevamente se hace mención a la mujer rural y no a la mujer campesina, justificado en la ley 731 del 2002 que comprende a la mujer rural como toda aquella que, sin distingo de ninguna naturaleza e independientemente del lugar donde viva, tiene una actividad productiva relacionada directamente con lo rural, incluso si dicha actividad no es reconocida por los sistemas de información y medición del Estado o no es remunerada. Esta definición incluye a las mujeres campesinas, indígenas y afro, sin tierras o con tierra insuficiente (FARC-EP y Gobierno de Colombia, 2016, p. 10).

A pesar de que la legislación provee de elementos sustanciales para poder considerar que los derechos de las mujeres rurales son protegidos y defendidos en el marco del Estado Social 
de Derecho, la realidad no es reflejo del marco jurídico abordado. Muchas de las condiciones de pobreza no se han superado, no existen avances tangibles y evidentes del Acuerdo de Paz de La Habana, el Fondo de Tierras para campesinos sin tierra o con poca tierra no ha sido dinamizado y la restitución encuentra poderosos enemigos en el poder judicial y legislativo.

El Estado menciona varias medidas legislativas y administrativas dentro de las que se incluyen las derivadas de la implementación del Acuerdo de Paz, priorizando la atención a mujeres en la adjudicación de baldíos y en la asignación de subsidios familiares de Vivienda de Interés Social Rural. Sin embargo, se evidencia en la descripción dada la alusión a mecanismos expedidos quedando en mora una evaluación específica de la implementación de estas medidas o programas, del presupuesto destinado y ejecutado y de la garantía de continuidad de las mismas (CEDAW, 2019, p. 15).

Tabla 6. Políticas públicas y mujer rural en Colombia.

\begin{tabular}{|c|c|c|}
\hline $\begin{array}{l}\text { Ley/Acuerdo/Iniciativa/Conve } \\
\text { nio/Decreto }\end{array}$ & Referencia a la mujer rural/campesina & Año \\
\hline Ley 160 & $\begin{array}{l}\text { Si bien promueve el acceso a la tierra de } \\
\text { la mujer campesina, limita la propiedad } \\
\text { colectiva. }\end{array}$ & 1994 \\
\hline Ley 731 & $\begin{array}{l}\text { Promueve la asociatividad y la empresa } \\
\text { de la mujer rural. }\end{array}$ & 2002 \\
\hline
\end{tabular}




\begin{tabular}{|c|c|c|}
\hline Ley 1725 & $\begin{array}{l}\text { Garantiza la protección patrimonial de la } \\
\text { mujer campesina. }\end{array}$ & 2008 \\
\hline Ley 1448 & $\begin{array}{l}\text { Promueve un enfoque diferencial para la } \\
\text { atención a las mujeres víctimas del } \\
\text { conflicto y de desplazamiento forzado. }\end{array}$ & 2011 \\
\hline Ley 21, Convenio 169 de la OIT & $\begin{array}{l}\text { Los Estados deberán instituirse } \\
\text { procedimientos adecuados en el marco } \\
\text { del sistema jurídico nacional para } \\
\text { solucionar las reivindicaciones de tierras } \\
\text { formuladas por los pueblos interesados. }\end{array}$ & $\begin{array}{l}\text { Ley } 1991, \\
\text { Convenio de la } \\
\text { OIT } 1989\end{array}$ \\
\hline Acuerdo de Paz de La Habana & $\begin{array}{l}\text { Establece la necesidad de garantizar una } \\
\text { transformación del campo colombiano a } \\
\text { partir de la economía campesina, la } \\
\text { distribución de la propiedad, priorizando } \\
\text { a las mujeres rurales víctimas del } \\
\text { conflicto armado y madres cabeza de } \\
\text { familia. }\end{array}$ & 2016 \\
\hline Decreto 2369 & $\begin{array}{l}\text { Creación de la dirección de mujer rural en } \\
\text { el Ministerio de Agricultura y Desarrollo } \\
\text { Rural que se encargará de brindar los }\end{array}$ & 2015 \\
\hline
\end{tabular}




\begin{tabular}{|l|l|}
\hline insumos necesarios para desarrollar \\
políticas e instrumentos diferenciales que \\
mejoren las condiciones de vida de la \\
mujer en el campo colombiano.
\end{tabular} \mid

Fuente: elaboración propia, 2020 


\section{CAPITULO III}

\section{MUJERES LIDERESAS Y CAMPESINAS DE FENSUAGRO:}

\section{APUESTA DE RESISTENCIA}

\section{1. ¿Quiénes son las mujeres de esta historia?}

Cuando lean mi trabajo se preguntarán por qué motivo decidí, además de los académicos ya expresados en la introducción, en lo personal abordar este tema; ¿por qué mujeres, por qué lideresas y por qué campesinas? La respuesta es la siguiente: cuando inicié la investigación para esta tesis doctoral ya venía cuestionándome el rol de las mujeres campesinas y lideresas en el marco del conflicto armado en nuestro país. El cual ha dejado ondas heridas y desesperanza en las mujeres campesinas en diferentes territorios. Ejemplo de esto son las mujeres lideresas del territorio de Sumapaz, víctimas algunas de la muerte de sus hijos y entregados estos en una morgue como guerrilleros para ser mostrados ante la opinión pública ${ }^{21}$, las mismas que sacaban fuerzas de sus entrañas para clamar al gobierno justicia, mientras seguían trabajando la tierra para el sustento de su familia y comunidad.

A esas digresiones se aúna como punto de referencia la región del Sumapaz por ser ésta el epicentro de varios movimientos sociales y de resistencia frente al conflicto y la violencia colombiana, la cual se manifiesta con características particulares en esta región.

\footnotetext{
${ }^{21}$ Falsos positivos: es el nombre con el que la prensa de Colombia denominó al involucramiento de miembros del Ejército de Colombia en el asesinato de civiles no beligerantes haciéndolos pasar como bajas en combate en el marco del Conflicto armado interno de Colombia.
} 
Ahora bien, estas particularidades no son sólo de su topografía, sino un compendio de lo social, lo cultural, lo político y económico y por supuesto lo humano. En este orden de ideas la región del Sumapaz comprende una gran parte de la zona rural de Bogotá, la cual es considerada además una de las reservas acuíferas más importantes del mundo. También una de las características de la zona del Sumapaz es ser un importante corredor natural que intercomunica distintas regiones tales como: los departamentos del Caquetá, Meta, Tolima y la misma capital del país. Esta región, como muchas más en Colombia, ha sido objeto de las políticas de defensa (Política de Seguridad Democrática) que trajeron como consecuencia constantes enfrentamientos con las guerrillas de las FARC, militarización del territorio y por ende la estigmatización de la población que como consecuencia ha traído la violación sistemática de los Derechos Humanos. Por esta razón la comunidad se ha venido organizado para desarrollar acciones de resistencia civil y pacífica frente al conflicto armado, acciones que en general están encaminadas a la defensa y conservación del Páramo como territorio.

Habría que decir también que la falta de presencia del Estado frente a las necesidades reales de la comunidad (más allá de la presencia militar) ha hecho que las mujeres campesinas se empoderaran frente a sus regiones a través de los sindicatos agrarios y sus justas reclamaciones. Mujeres que demandaban justicia y que, como una de ellas misma lo expresaba, "No parí un hijo para que me lo vengan a matar, cuando no son los paras es la guerrilla y cuando no son ninguno de estos es el ejército pa decir que están limpiando la zona de la guerrilla". Lamentos como estos que hacían eco ininterrumpido en boca de tantas campesinas.

Es así como, casi como un juego del azar, conocí a varias mujeres en el sindicato de SINTRAPAZ en la región de Sumapaz. Estas mujeres lideresas campesinas ya venían 
haciendo resistencia a través de agremiaciones sindicales, y sin darme cuenta una cosa llevó a la otra y un día cualquiera ya estaba participando en un congreso de soberanía alimentaria en Viotá Cundinamarca, una región fértil y hermosa, enmarcada en una violencia fuerte por la tenencia de las tierras que dieron origen, como en el Tolima, a las primeras guerrillas y que en la búsqueda de una reforma agraria vieron morir a muchos de sus hombres y mujeres. En este congreso me percaté de la participación activa de muchas mujeres que estaban liderando y que, a diferencia de lo que yo pensaba, eran mujeres estructuradas, con conocimientos algunas en derecho, con gran fluidez verbal y como es lógico un minucioso conocimiento de sus tierras. Ver esto me llenó de satisfacción y me hizo comprender que la participación de la mujer campesina no es sólo una utopía sino que es una realidad. Cuando me acerqué para hablar con ellas noté cierta reserva y un poco de timidez, pero cuando les expresé mi admiración e inquietud por lo que venían haciendo se abrieron y me comenzaron a comentar sus vivencias y sus luchas, de esta manera se fue tejiendo un acercamiento fraternal para convertirme casi en parte de su grupo. En ese momento vislumbré que existía un hilo conductor en estas mujeres que era su vinculación a FENSUAGRO. Emergió entonces el tema de mi tesis: "La participación de las mujeres campesinas agremiadas en un sindicato: FENSUAGRO”. Pero a pesar de lo anterior, ahora lo que me apremiaba, era cómo estructurarlo para no enmarcar a la mujer campesina en una perspectiva de victimización o de un feminismo ramplón, sino, reconocerla en su rol de lideresa campesina.

Desde esta óptica, poco a poco estas mujeres me fueron dando (sin darse cuenta) esa respuesta. Cuando hablé con Nury, una líder campesina conocedora de su territorio y de FENSUAGRO, me di cuenta que tenía que ahondar más en el asunto y es así como le pedí que me contara su historia. Ella me relata que es hija de campesinos y que sus padres y 
hermanos habían venido siendo parte de FENSUAGRO, hecho este y que les había mostrado un horizonte para ayudar a muchas familias campesinas; no solo mostrándole su derecho, sino otras alternativas para los jóvenes y mujeres que tras años de violencia parecían condenados a pertenecer a grupos armados (guerrilla, paramilitares o Ejército). Así como para los hombres ser pequeños minifundistas, ante la poca oportunidad de estudio y para las mujeres, la crianza de los hijos, los animales de granja y la siembra. Dinámicas todas estas implantadas como una forma de sometimiento y para perpetuar todos estos sistemas de inequidad e injusticia social.

Cabe señalar que hablar con Nury no sólo me develó una realidad de mi país que aún muchos ignoran, sino que me sirvió para concientizarme de esta situación. En su relato notaba en su voz entusiasmo y el amor por su trabajo en FENSUAGRO por los aportes que daba a las comunidades campesina. Me hace feliz saber que hoy en día no sólo es una mujer líder campesina, sino que es la primera mujer presidenta de una organización tan importante a nivel sindical como lo es FENSUAGRO. Gracias a ella fui interactuando con muchas mujeres líderes campesinas de diferentes regiones; cada una con diferentes experiencias de vida, pero con un factor en común: la violencia, la discriminación, la estigmatización, la revictimización y el dolor de sus muertos. Estas mujeres que abrieron su corazón y sus historias de vida me mostraron otras perspectivas de lo que es resistir, liderar y ser mujer campesina; mujeres que se resisten a abandonar sus tierras, su cultura, su legado, su vida.

A propósito de esta interacción con las líderes campesinas compartí con Sofía (lideresa campesina de los Montes de María), una de las líderes sociales que confió en mí para desahogar su alma. Ella me describió de una manera transparente y nostálgica el sitio donde vive, una región llamada los montes de María, ubicada en una población de la sabana 
del departamento de Sucre. Me comentaba que durante todo el año presenta un clima caluroso que va desde los 28 hasta los 36 grados centígrados y que por sus condiciones climáticas es una tierra utilizada para la ganadería y cultivos de yuca, ñamé, maíz, arroz, plátano, tabaco, café y aguacate. Ella expresa que estas tierras serían todo un paraíso, pero que lamentablemente no es así, porque se ha visto a lo largo de la historia como un refugio de grupos guerrilleros y en los últimos años grupos paramilitares. Estos grupos paramilitares han venido cometiendo graves abusos a hacia la población: masacres, violaciones a mujeres y desplazamientos forzados, reclutamiento de menores y otras violaciones al Derecho Internacional Humanitario (DIH), lamentablemente muchas de ellas en connivencia de órganos estatales). Sofía me decía en tono inconforme que desde muy joven ella sabía que la vida no sólo era matarse en el campo como lo habían hecho sus padres y vivir con tanta injusticia, esperanzados sólo en pasar el día a día y no y esperando el ocaso de sus días. Ella pensaba en que debía hacer algo distinto y por esta razón, comenzó a capacitarse, a familiarizarse en la lectura de libros sobre socialismo, comunismo, equidad social, resistencia etc. Esto la llevó a iniciar un proceso de acercamiento a grupos de hombres y mujeres con intereses afines. Sin embargo, Sofía observó cómo la participación de las mujeres era muy limitada debido a que la gran mayoría de ellas estaban siendo, de una u otra manera, relegadas por el régimen patriarcal. Pero, aun así, ella continúa con la idea de seguir buscando mayor participación para las mujeres. Es así como estando inmersa dentro de estos movimientos encuentra su compañero de vida y de lucha, con el cual conforman una familia; y ahora como madre de dos hijos es parte activa del comité de agricultores de FENSUAGRO en la región. Su proceso de capacitación la hace más consiente de la situación en que viven y la alerta sobre la violación sistemática de los derechos humanos de su comunidad (por parte de diversos grupos, incluyendo el Estado). 
En este orden de ideas, a través de su relato ella comenta que muchos de sus compañeros cuando denunciaban las situaciones arbitrarias: violación de derechos humanos, minería ilegal, daño al medio ambiente, extorsión, desplazamiento, etc., eran amenazados y muchos de ellos asesinados. Sofía, con un tono de indignación y a la vez de firme denuncia, argumenta que al estar en esta situación los miembros sindicales y campesinos solo tienen dos opciones: o esconderse o exiliarse. Pero pese a todo esto, Sofía piensa que no todo está perdido y que continuará resistiendo y apoyando a la comunidad, a través de las mujeres, a través de la educación con charlas sobre la protección a su tierra, la defensa de los derechos humanos. Ella cree firmemente que estas acciones, junto con el cuidado de sus animales (gatos y perros) le permiten aportar su granito de arena para la esperanza de su comunidad. Esta líder, se autodenomina defensora de derechos humanos, ambientalista y animalista.

Dentro del acercamiento a estos relatos pude conocer a otra líder campesina: Aidé Moreno. Mujer recia de temperamento forjado en los tornos del dolor y la lucha social; integrante activa perteneciente al comité ejecutivo de FENSUAGRO. Un punto de quiebre en su historia se da cuando sale (por motivo de amenazas hacia su vida e integridad) de la población del Meta en los llanos orientales colombianos, con rumbo al municipio de Soacha que se encuentra ubicado muy cerca de Bogotá. En su relato ella comenta que creció como mujer campesina y que poco a poco descubre su vocación como líder, abriéndose camino en un entorno hostil y machista.

De esta circunstancia inicia su vinculación y participación activa en los procesos de formación de otras mujeres, con el fin de que ellas pudieran descubrir su gran valor y liderazgo, ampliando así su horizonte; llenándose de oportunidades e ideales para hacer su existencia más digna y trascendental. Aidé comenta que su familia ha estado siempre muy 
comprometida en los procesos de liderazgo en la región del Meta y que en muchas ocasiones han sido amenazados.

De manera irónica dos semanas después de haber realizado la entrevista con Aidé, las noticias que me llegan me hacen sentir un fuerte escalofrió, al enterarme que su hermano Omar Moreno, líder social integrante del Sindicato de SINTAGRIM (Sindicato de Trabajadores Independientes del Meta) y sobreviviente de la Unión Patriótica había sido asesinado. "La comunidad ha informado que OMAR, fue asesinado y desaparecido porque circularon en esa región imágenes y videos desgarradores de la tortura y asesinato de la cual fue sometido, por un grupo armado que se hace llamar Oliver Sinisterra". Este tipo de situaciones que a traviesan no sólo las mujeres lideresas campesinas sino muchos líderes sociales que lo viven a diario, me dejan realmente conmocionada pues me queda la sensación de que la historia se repite una y otra vez en la más completa impunidad y ante los ojos indiferentes de una sociedad que tristemente naturalizó la violencia como parte de nuestra cultura.

Siguiendo el orden de mi relato, vale la pena mencionar a otra de las lideresas campesinas: Yira del Carmen. Mujer oriunda de Sucre y radicada en Viotá Cundinamarca de origen campesino, la cual es administradora pública y se autodenomina hija de FENSUAGRO. Su familia desde siempre ha hecho parte del sindicato y fue formada académicamente en el mismo. Yira el Carmen hace parte del comité ejecutivo de lideresas y cuenta con orgullo que es madre de un bello bebé. En este momento está dedicada a trabajar con el equipo organizativo de desarrollo en la construcción de la Instituto Agroecológico Latinoamericano (IALA María Cano) Universidad Campesina de FENSUAGRO. En este trabajo ha encontrado no solo su realización como lideresa, sino ha sido un factor calve de 
resistencia ante una sociedad tan desigual y de gran satisfacción personal al ver como otras mujeres son parte de esta apuesta en común a través de la educación.

Dentro de estos relatos no podía faltar la figura de la maestra y esta figura la encarna Lorena Sánchez; madre de dos hijos y presidenta de la Asociación de Trabajadores Campesinos del Huila. Esta organización campesina de base tiene su origen en el departamento del Huila, donde tiene presencia en 15 municipios de los 37 municipios que tiene el departamento (hace parte de FENSUAGRO). Esta maestra muestra la pasión que la caracteriza, y de manera anecdótica me comenta que las personas (tanto hombres y mujeres) entran en desconcierto cuando ella se denomina mujer campesina y se presenta como tal. Este desconcierto es ocasionado por el imaginario de la mujer campesina como una mujer de trenzas, canasto y alpargatas, de vocabulario reducido, e ignorante de las problemáticas sociales en todo sentido. Pero Lorena no encaja en este imaginario, a pesar de ser ella una mujer campesina, hija de campesinos conocedores de la tierra. Quizá por este errado imaginario, ella ha sido víctima del descreimiento y desconfianza, lo cual ha hecho más difícil su situación, porque no sólo ha tenido que luchar contra estos esquemas con sus pares sino demostrar que es una líder de su comunidad. En relación con lo anterior, su tesón y perseverancia la han llevado a ser juzgada y ha sido víctima de desplazamiento forzado, como ella lo expresa: "Otro tema también es el señalamiento, atentados, perdida de familiares. El sistema identifica a cuál líder se le puede hacer daño y eso acá es muy fuerte, contra el nombre de Lorena Sánchez, acá dicen que alias la Mona, que trabaja en no sé qué. Sí sé cuándo, me hicieron un atentado, eso trae unos costos, es duro, pero ahí estamos. En el paro del 2013 a mí me sacaron de acá para Bogotá, me tocó sacar mis hijos, me llegaron a donde vivía a matarme, me llegaron dos veces a media noche y la misma gente me ayudó 
a salir, y es dificil, pero ha valido la pena. Y cuando se dan cuenta de que a los que hay que atacar es el líder, el que moviliza, identifica esos liderazgos y en las emisoras del Ejército empiezan a ofrecer recompensas, y toda la gente tenía miedo y nadie salía, si yo citaba a una reunión ya nadie salía, porque sabían que me iban a matar. Es estigmatizar el nombre a tal punto de acabarme politicamente, ha sido fuerte, incluso en la izquierda yo saqué la mayor votación y otros compañeros me decían 'usted es la jefe política de la izquierda por la votación que sacó' y me decían 'es que acá el jefe debe ser un varón', el machismo es muy fuerte y menos van a aceptar que una mujer del campo, que viene de liderar movilizaciones, cosas como esas, sea el referente político de la alternatividad". Estas desgarradoras confesiones me hacen pensar la lucha de la mujer para poder lograr tener el respeto en una sociedad tan patriarcal como la nuestra que es bastante difícil ser mujer, madre, maestra y líder social.

Sumado a los anteriores relatos y continuando con el papel de las maestras me encontré con Maidani Salcedo. Mujer, madre y abuela, que me comenta su historia de vida haciendo énfasis en ser mujer campesina. Mujer oriunda y orgullosa en su natal Tolima, pero criada entre los Llanos Orientales, Huila y Caquetá, lo que le da una visión muy amplia de la situación de las mujeres y hombres campesinos. Ella siempre ha estado preocupada por conservar la historia y las tradiciones, razón por la cual acoge un grupo de niños, para, como ella lo denomina, fomentar un círculo de lectores. En este espacio ella brinda una formación de la historia de Colombia, a través de la lectura de biografías de Bolívar, Policarpa y Pedro Pascasio Martínez y otros próceres de la historia. Todo este trabajo lo desarrolló con los niños 
y jóvenes de San Vicente del Caguan ${ }^{22}$. Luego de esta experiencia formativa debe salir de allí desplazada por amenazas para la ciudad de Neiva; donde con sus hijas y nietos fue acogida por una organización Fundación Nueva Esperanza: “alli di mis primeros pasos como dirigente desplazada, campesina en un campo de asfalto y fue duro, porque no conocía".

Maidani me comenta que su historia hasta ahora inicia, con su voz quebrantada y sus ojos llorosos que el ser líder campesina siempre ha sido algo natural para ella: "virgen santa, bueno, no sé si es que uno nace con eso, somos muchas compañeras que estamos en la junta directiva de la organización en Piamonte y todas le metemos perrenque y entusiasmo; sin embargo algunas les da más miedo que otras. Algunas nos dan miedo y lo volvemos en valor, es un desafio luchar por las demás personas. En Piamonte tenemos 700 afiliados, y de esos agradecerán 100; entonces ser líder campesina es duro, pero gratificante porque me gusta y me nace, siento el respaldo de las comunidades, me siento bien, aunque a veces siento que se me va el aire porque es una de las organizaciones más perseguidas y he sido muy amenazada, me han echado bala, han desplazado mi familia. Por ejemplo el 17 de diciembre del año pasado (el cartel de Sinaloa) me dio 24 horas para sacar a toda mi familia; creíamos que con los acuerdos de paz se podía vivir mejor pero ha sido difícil, le quedo grande al gobierno, pareciera que a ellos les gustara el narcotráfico porque cuando uno impulsa los acuerdos de La Habana es perseguido y estigmatizado. Es duro, es un desafio muy grande. Lo único que me da fuerza es que cuento con el respaldo de mi pareja, me respalda, aunque sienta miedo, pero no es el que critica, el que se va, él está pendiente de los quehaceres de la casa y la finca mientras nosotros hacemos el trabajo. Me llegó el sentimentalismo."

\footnotetext{
${ }^{22}$ San Vicente del Caguan fue una de las Zonas de despeje en el gobierno del presidente Andrés Pastrana con el proceso de diálogos del Paz en el año 2002.
} 
Finalmente, María Eugenia otra lideresa campesina, oriunda del Uraba, zona bananera de grandes cultivos, pero también de diversas formas de violencia y en donde en la actualidad es una zona con alta presencia paramilitar. Pero también podemos decir que Urabá es un paisaje exótico que maravilla por sus inmensos cultivos de plátano y gran diversidad cultural. Siguiendo con su relato María Eugenia me comenta cómo las mujeres se han venido abriendo un camino al reconocimiento sindical y como a través de SINTRACOL, el sindicato de la agroindustria de los trabajadores bananeros de Urabá (creado el 13 de febrero de 2013), que actualmente se llama SINTRAINAGRO, mujeres como ella han logrado posicionarse, siendo este el segundo sindicato más importante de la región. Ella expresa textualmente: "hemos ido creciendo a través de un trabajo serio, con dedicación, hemos ido avanzando y esta agremiación sindical nos ha dado fuerza para continuar con más ahínco y esperanza".

Llena de orgullo María continúa diciéndome: "Yo he adquirido mucho conocimiento; defender mis derechos, el de mis compañeras, orientarlas, guiarlas a través del conocimiento que hemos adquirido en FENSUAGRO, porque la federación se enfoca en formar y fortalecernos para que crezcamos y sepamos defender nuestros ideales. Acá somos muchas madres de familia, en todos los escenarios esa es la parte que más resalto, a nosotras nos han matado hijos, hermanos, todo, debido a la violencia, eso ha sido muy difícil, duro, en el Urabá hemos sido las más sufridas y sacrificadas por todas las olas de la violencia en el país; nosotras hemos sido las más perjudicadas”. Al finalizar su narrativa en su rostro se enmarca una gran sonrisa de satisfacción, la misma que he visto en todas aquellas mujeres que siguen luchando, no sólo por sus derechos sino el de toda su comunidad y país. 


\subsection{Ser mujer y ser campesina, un reto}

Las exigencias de las mujeres rurales y campesinas se han posicionado en el debate público, no sólo en la lucha por los derechos de propiedad, sino por el reconocimiento de su condición de mujer rural y lo que ello significa. En los últimos años, se ha posicionado el debate al interior de las organizaciones campesinas el rol dentro de la familia, el patriarcado y la apertura de escenarios paritarios en donde tengan voz y voto en las dinámicas propias de los movimientos.

Lamentablemente, la situación actual no es positiva para los liderazgos del movimiento social en Colombia. Desde la firma de los Acuerdos de La Habana (2016), que en esencia promovían la participación de las organizaciones sociales en la transformación del país desde los territorios, y que tenía especial énfasis en el enfoque diferencial de género y territorial, han sido asesinados aproximadamente 555 líderes y lideresas sociales en diferentes regiones del país.

De acuerdo con Negret (Defensor del Pueblo), entre el $1^{\circ}$ de enero de 2019 y el 31 de octubre del mismo año se presentaron 118 asesinatos de líderes y lideresas sociales y defensores y defensoras de derechos humanos (99 hombres y 19 mujeres). En ese mismo sentido, en 2016 fueron 133 casos (117 hombres y 33 mujeres); en 2017, los asesinatos fueron 126 (108 hombres y 18 mujeres); y en 2018, la cifra llegó a 178 (166 hombres y 12 mujeres) (Defensoría del Pueblo, s.f., pág.36).

Aunque la Defensoría del Pueblo destaca una ligera reducción en los homicidios entre 2018 y 2019, hay un aumento exponencial del 63\% de asesinatos de lideresas sociales. El 
informe elaborado por la ONG Oxfam llamado "Defensoras de derechos agrarios, territoriales y medioambientales en Colombia: arriesgando la vida por la paz" (2019), destaca que las mujeres que han sobresalido por su defensa de los territorios, el medio ambiente y las tierras, son más propensas a ser asesinadas. Lo que significa que la defensa de estos tres ejes -tierras, territorio y medio ambiente-, se convierte en una actividad de alto riesgo por los intereses que confluyen en las regiones del país y la presencia de grupos armados ilegales.

Como informa la Fundación Paz y Reconciliación (PARES): las mujeres, entonces, tienen menos oportunidades de representar a sus comunidades, pues su trascendencia en la esfera pública aún es limitada. Y, cuando lo hacen, corren el riesgo de sufrir homicidios, amenazas, violaciones sexuales y desplazamientos, lo que desincentiva el surgimiento de nuevas mujeres líderes. Del total de defensores asesinados desde la firma de los Acuerdos de Paz, más de 300 según Indepaz, el 20\% ha sido contra lideresas (PARES, 2018, pág.57).

Distintos elementos han configurado un cóctel mortal para el ejercicio del liderazgo femenino en Colombia: su origen, pues son líderes afro, campesinas o indígenas, identidades que han generado históricamente procesos de estigmatización. Las regiones donde desarrollan sus actividades, pues son territorios en disputa por diferentes actores y sobre los que se ciñen distintos intereses particulares. Por último, la sistemática indiferencia y poca o nula voluntad política de investigar, condenar y reparar a las víctimas por parte del Estado Colombiano.

La respuesta del Gobierno colombiano para revertir esta grave situación apenas ha tenido un impacto efectivo sobre las defensoras, a pesar de los numerosos marcos normativos que en teoría deberían protegerlas. El Gobierno de Iván Duque llegó al poder en 2018, año en el que el país volvió a batir otro trágico récord como el más violento contra los defensores 
de derechos humanos. En su mano estaba revertir esta tendencia y poner en marcha las medidas necesarias. Aunque inició su investidura señalando que trabajaría “incansablemente" por proteger a los líderes sociales, sus palabras no se han convertido en políticas efectivas para prevenir los ataques (OXFAM, 2019, p. 4).

Mapa 5. Lideresas asesinadas 2016-2019

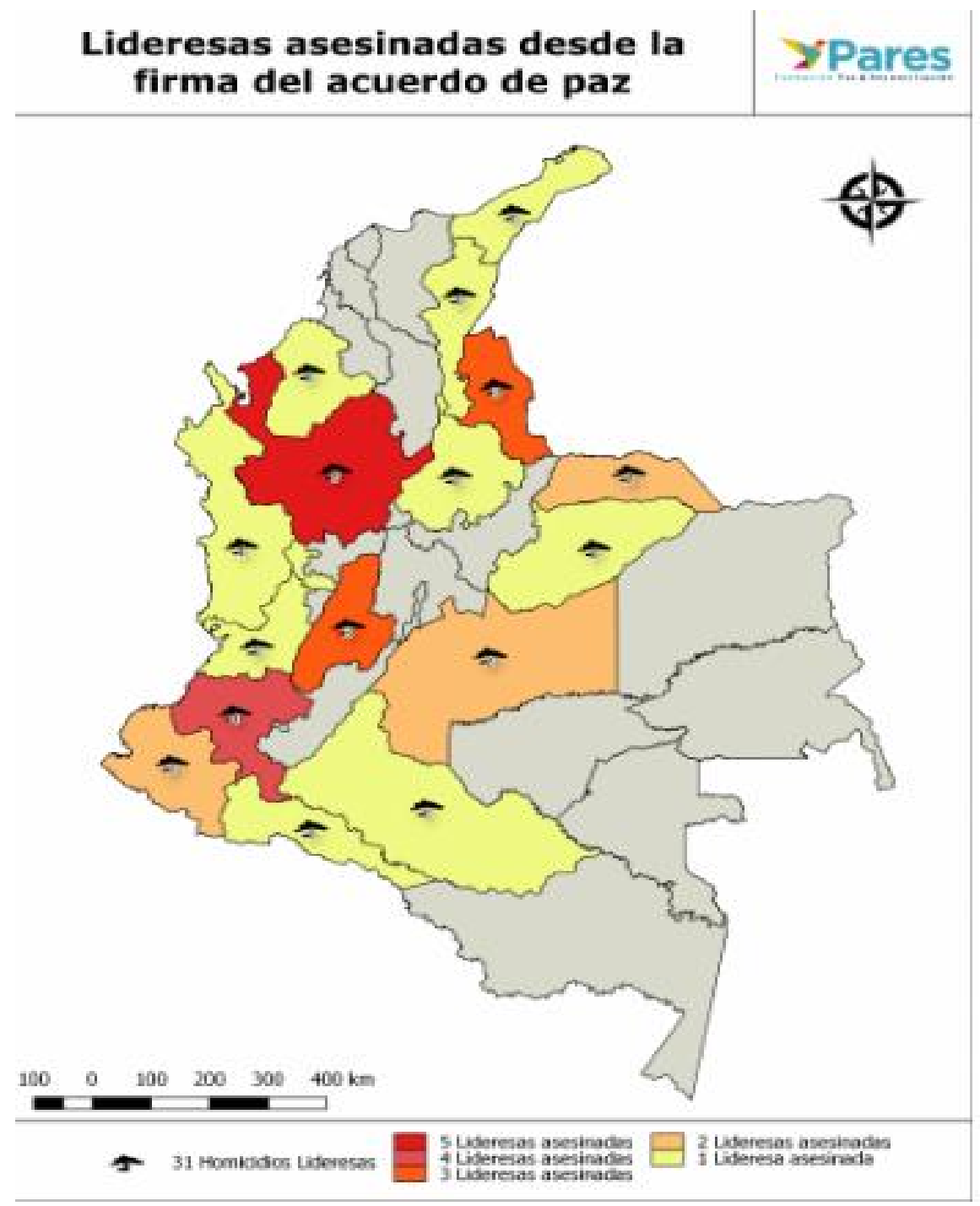

Fuente: Pares, 2019 
Producto del informe elaborado por la OXFAM y teniendo en cuenta las cifras, esta ONG recomienda al Gobierno Nacional encabezado por Iván Duque facilitar el proceso de denuncias, promover el enfoque preventivo, poner en marcha los mecanismos de protección, garantizar la participación comunitaria y fortalecer los procesos organizativos. Combatir el crimen con medidas efectivas que disminuyan los altos índices de impunidad, desmontar las estructuras criminales y profundizar las investigaciones frente a las relaciones de los grupos armados ilegales con individuos u organizaciones de la "legalidad".

Una vaca tiene más derechos que una mujer. Una vaca tiene derecho a una hectárea de tierra. Y las mujeres no tienen tierras, no tienen tierra ni en las uñas. Una vaca tiene derecho a vacunación, y eso es sagrado acá, tiene [el] tema [de la] desparasitación, tiene un veterinario, tiene un control. Las mujeres rurales no tienen un centro de salud, no tienen [ni] el tema de la educación (OXFAM, 2019, Defensora Campesina, p. 20).

De igual manera, es imperante reconocer públicamente la labor de los y las defensores de la tierra, el territorio, el medio ambiente y la vida, así como acelerar la implementación de los Acuerdos de La Habana, sobre todo en el punto de tierras, la sustitución concertada de cultivos de uso ilícito y generar medidas efectivas de protección de los ecosistemas. Sin embargo, los intereses políticos del actual gobierno son evidentes y están orientados a favorecer la megaminería y los intereses privados con sofismas basados en el desarrollo, la sostenibilidad ambiental y la dinamización económica de los territorios.

El auge de la economía extractivista ha marginado a las mujeres, que no son contratadas por la industria más que excepcionalmente. Y para quienes han vivido en sus cuerpos el incremento de los casos de violencia sexual y física, además, ha traído consigo 
una mayor vulneración de sus derechos, mediante redes de trata de personas, explotación sexual y prostitución forzada. Se suman, además, la criminalización de la protesta, la persecución, la muerte política, la social y, finalmente, la física. Y, en sus territorios, la contaminación, la inseguridad, desplazamiento y las amenazas también se han generalizado (OXFAM, 2019, p. 20).

Si se realiza una superposición de los mapas de crímenes contra líderes y lideresas sociales con los mapas de extracción minera o petrolera y los de presencia de actores armados, es posible afirmar que en la realidad que se vive en dichas regiones existe un patrón de los asesinatos contra los defensores de DD.HH., el territorio y el medio ambiente. Por tal razón muchas organizaciones han afirmado que se ha convertido en una labor de alto riesgo, incluso calificando a Colombia como el peor país del mundo para el ejercicio de la defensa de las diferentes causas mencionadas anteriormente ${ }^{23}$.

Tabla 7. Lideresas sociales asesinadas en el 2019

\begin{tabular}{|l|l|l|}
\hline Departamento & Lideresas asesinadas & Movimiento \\
\hline Tolima & 3 & Junta de acción comunal, \\
& & Sindicato de maestros. \\
\hline Córdoba & 1 & Movimiento estudiantil. \\
\hline
\end{tabular}

${ }^{23}$ Colombia: el país latinoamericano con más asesinatos de defensores de derechos humanos señala experto: https://news.un.org/es/story/2020/03/1470571.

Colombia, el país donde más asesinan defensores ambientales: https://sostenibilidad.semana.com/impacto/articulo/colombia-el-pais-donde-mas-asesinan-defensoresambientales-en-el-mundo-hoy/53492. 


\begin{tabular}{|c|c|c|}
\hline Cauca & 4 & $\begin{array}{l}\text { Fensuagro, junta de acción } \\
\text { comunal, Movimiento de } \\
\text { víctimas, } \\
\text { Indígena. }\end{array}$ \\
\hline Valle del Cauca & 1 & Defensora de DD.HH. \\
\hline Cesar & 1 & $\begin{array}{l}\text { Defensora de DD.HH. y de } \\
\text { los pueblos indígenas. }\end{array}$ \\
\hline Antioquia & 5 & $\begin{array}{l}\text { Junta de acción comunal, } \\
\text { Cumbre } \\
\text { Movimiento por la } \\
\text { restitución de tierras, } \\
\text { Campaña Petro presidente. }\end{array}$ \\
\hline Meta & 2 & $\begin{array}{l}\text { Cumbre Agraria, } \\
\text { Movimiento de sustitución } \\
\text { de cultivos de uso ilícito. }\end{array}$ \\
\hline Casanare & 1 & Junta de acción comunal. \\
\hline Santander & 1 & Movimiento campesino. \\
\hline Arauca & 2 & $\begin{array}{l}\text { Junta de acción comunal, } \\
\text { Movimiento campesino. }\end{array}$ \\
\hline Caquetá & 1 & Movimiento campesino. \\
\hline
\end{tabular}




\begin{tabular}{|l|l|l|}
\hline Nariño & 2 & $\begin{array}{l}\text { Movimiento de víctimas, } \\
\text { junta de acción comunal. }\end{array}$ \\
\hline Norte de Santander & 3 & Junta de acción comunal. \\
\hline Chocó & 2 & $\begin{array}{l}\text { Movimiento ambiental y } \\
\text { Junta de acción comunal. }\end{array}$ \\
\hline Putumayo & 1 & Movimiento de mujeres. \\
\hline La Guajira & 1 & Promotora de la campaña \\
& & Petro presidente. \\
\hline
\end{tabular}

Fuente: Elaboración propia con información de PARES 2020.

La tabla número 2 nos da elementos para el análisis de la situación de las lideresas en el país. El patrón mayoritario de las mujeres asesinadas en el 2019 se define por su participación en movimientos campesinos o de restitución de tierras, así como la labor comunitaria en barrios y veredas. Los resultados del último informe anual de la ONG británica Global Witness revelaron que, de 212 ecologistas asesinados en 2019, 64 víctimas se reportaron en el país. Entre tanto, en Filipinas asesinaron un total de 43, lo que indica que la mitad de los homicidios ocurrió en estos dos países. Los más afectados fueron líderes indígenas, guardabosques y activistas (Semana, 2019).

No es casualidad que el ranking de Global Witness lo encabecen Colombia, Filipinas y Brasil, pues son países en donde la profundización del modelo extractivista y de monocultivos, así como de destrucción de los recursos naturales se ha dado con bastante 
ahínco. Existe entonces una relación íntima en ampliación del modelo económico capitalista en su fase neoliberal y el asesinato de quienes presentan resistencia a la destrucción de los territorios. En este contexto, FENSUAGRO se consolida como una de las organizaciones que presenta una férrea defensa de pilares como la implementación de los acuerdos de paz, la Reforma Rural Integral, la defensa de la economía campesina y del medio ambiente.

Ahora bien, un elemento particular pero que se enmarca en esta situación de violaciones a los derechos humanos y exterminio son los asesinatos a excombatientes de las FARC-EP, quienes se acogieron al proceso de paz, dejaron las armas y desarrollan su proceso de reincorporación a la vida civil. Varios son los elementos que han significado un peligro latente para esta población.

En primer lugar, el incumplimiento sustancial y sistemático por parte del gobierno nacional en la implementación de los acuerdos, en lo que respecta al punto de tierras, sustitución concertada de cultivos de uso ilícito y proyectos productivos. En segundo lugar, el rearme y reorganización de grupos paramilitares que actúan con nombres "renovados" y sofismas utilizados por la institucionalidad para negar la presencia y el fortalecimiento de este fenómeno, que según el acuerdo debe ser atacado con contundencia. En tercer lugar, la actuación de miembros del Estado, específicamente del Ejército de Colombia en el exterminio de excombatientes, como por ejemplo el caso de Dimar Torres, asesinado en el Departamento del Norte de Santander por supuestas órdenes del coronel en retiro Jorge Pérez Amézquita ${ }^{24}$.

24 Ver: ¿Qué viene en el caso por el asesinato de Dimar Torres? https://www.eltiempo.com/justicia/delitos/condenado-a-20-anos-militar-que-asesino-a-dimar-torres-438270. Ver: Coronel investigado por asesinato de Dimar Torres quedó inhabilitado por 20 años. https://www.elespectador.com/noticias/judicial/procuraduria-sanciono-a-militares-investigados-por-asesinatode-dimar-torres/ 
En este contexto las organizaciones sociales, campesinas, indígenas, étnicas y populares, desarrollan sus labores en defensa del territorio, los Derechos Humanos, la paz y la transición a la democracia, en un momento en que los órganos de control y las ramas del poder se encuentran en su mayoría, alineadas con los intereses políticos del gobierno de turno.

\subsection{Voces de resistencia, resiliencia y empoderamiento de lideresa}

\section{campesinas en Colombia}

Ser mujer y ser campesina es una característica que en Colombia conlleva a situaciones diversas, pero en la mayoría de los casos significa hacer parte de una porción de la población que históricamente ha sido segregada y excluida. Los datos de pobreza demuestran que por dos hombres que en la pandemia por cuenta del COVID-19 han perdido el trabajo, siete mujeres han perdido su trabajo. Esta situación está dada para las zonas urbanas, pero en las zonas rurales las circunstancias y particularidades territoriales son diferentes, e incluso son mucho más profundas y complejas por cuenta de elementos culturales como el machismo propio de la vida en el campo y la violencia ejercida por diferentes grupos armados que han encontrado en la mujer un botín de guerra.

En el transcurso de esta investigación se entrevistaron siete mujeres lideresas campesinas que hacen parte de FENSUAGRO. Las conversaciones con ellas se orientaron a partir de preguntas abiertas, con el objetivo de crear un ambiente de confianza y seguridad. A su vez, es importante destacar que las mujeres entrevistadas tienen una vasta experiencia organizativa en los procesos populares campesinos de defensa de la tierra, la biodiversidad, la economía campesina y el territorio. Al realizar un análisis de las entrevistas a partir del software Atlas. Ti, se puede evidenciar que existen diferencias y patrones que se repiten. La 
gran mayoría de las mujeres líderes y campesinas entrevistadas que hacen parte de FENSUAGRO empezaron su vida organizativa desde muy temprana edad. En la mayoría de los casos, la organización veredal representada en la Junta de Acción Comunal (JAC) fue el primer paso para que las mujeres, quienes aportaron sus experiencias en la construcción de esta tesis, iniciaran su formación política.

Desde luego, las siete lideresas mujeres son de origen campesino. Aunque FENSUAGRO no discrimina a sus miembros por el origen social de estos, es indudable que el origen campesino de su base social es pieza fundamental para considerarse una organización campesina, un sindicato agrario. La ubicación geográfica de las mujeres líderes campesinas de FENSUAGRO tiene mucho que ver con la herencia de luchas por la tierra y de organizaciones agrarias de vieja data. La gran mayoría de ellas se ubica en Norte, Centro y Sur del país, siendo Bolívar, Huila, Cauca, Tolima y Cundinamarca los departamentos donde se han registrado no sólo fuertes despliegues de las organizaciones campesinas, sino además una tradición de movilización y resistencia frente a la violencia, el desplazamiento forzado, las intimidaciones y los señalamientos.

Tabla 8. Ingreso de las Mujeres Lideres Campesinas a FENSUAGRO

\begin{tabular}{|l|l|}
\hline Lideresas & Testimonios de su ingreso a FENSUAGRO \\
\hline Lorena Sánchez & Llego siendo líder porque en mi comunidad estuve en las JAC de la \\
& vereda, es el organismo base de las comunidades base para poder \\
& acceder a recursos y proyectos. Cuando me vinculo a FENSUAGRO \\
\hline
\end{tabular}




\begin{tabular}{|c|c|}
\hline $\begin{array}{l}\text { Líder agraria oriunda del Huila, } \\
\text { combatiente de las políticas } \\
\text { corruptas y representante del } \\
\text { campesinado, mujeres y } \\
\text { jóvenes de su región. }\end{array}$ & $\begin{array}{l}\text { es a través de la Asociación Campesina. En el Huila no teníamos } \\
\text { interlocutor con personería jurídica que representara a las } \\
\text { asociaciones, a las agremiaciones, a las juntas, cooperativas, } \\
\text { corporaciones y cuando había paros o movilizaciones llamaban a los } \\
\text { sectores; pero por ejemplo cuando pensaban en indígenas llamaban a } \\
\text { la ONIC, pero cuando llamaban a las organizaciones campesinas } \\
\text { había muchas y no había la manera de integrar todo, de entender que } \\
\text { todo era integral, estructural y cada uno peleaba por la vereda, y en } \\
\text { un paro no encontrábamos como negociar de manera unificada } \\
\text { porque teníamos pliegos diferentes, uno pedía vías, el otro pedía } \\
\text { placa huella, x o y, y decidimos que el campesino necesitaba una } \\
\text { figura jurídica para interlocutar en caso de movilizaciones y para } \\
\text { organizar el sector campesino. Es allí donde nace la idea de la } \\
\text { Asociación de Campesinos del Huila, cuando se da eso, le damos } \\
\text { forma jurídica y FENSUAGRO nos hizo el acompañamiento. }\end{array}$ \\
\hline $\begin{array}{l}\text { Maidani Salcedo } \\
\text { Originaria de Río Blanco } \\
\text { Tolima, pero criada entre las } \\
\text { zonas de Guayabero, la } \\
\text { Concordia (Meta), Caquetá, } \\
\text { Huila y San José del Guaviare. } \\
\text { Madre de dos hijos y se }\end{array}$ & $\begin{array}{l}\text { Mis primeros pasos fueron en los saberes de Nury, Aidé y Everto, me } \\
\text { formaron en las escuelas de mujeres, de DD.HH., en la formación } \\
\text { política, asumí poco a poco liderazgos y luego me metí de lleno. De } \\
\text { pronto no les puse mucha atención y aun me falta ser esa gran } \\
\text { dirigente, ellos han sido el ejemplo para mí, para seguir. Yo quisiera } \\
\text { llegar a ser algún día parecida a Nury, Aidé, porque son personas que }\end{array}$ \\
\hline
\end{tabular}




\begin{tabular}{|c|c|}
\hline $\begin{array}{l}\text { desempeña como lideresa en el } \\
\text { campo social promulgando los } \\
\text { derechos de la niñez. }\end{array}$ & $\begin{array}{l}\text { son muy capacitadas para dar debates, para hablar, yo también lo } \\
\text { hago, pero de pronto no de la misma talla. }\end{array}$ \\
\hline $\begin{array}{l}\text { Nury Martínez } \\
\text { Lideresa y Presidenta de la } \\
\text { Federación Nacional Sindical } \\
\text { Unitaria Agraria, Miembro de } \\
\text { la Vía Campesina y lucha en } \\
\text { defensa de los Derechos } \\
\text { Humanos. }\end{array}$ & $\begin{array}{l}\text { Mi mamá siempre fue organizada, hemos sido víctimas y tuvimos que } \\
\text { salir de varias regiones, pero mi mamá siempre estuvo organizada y } \\
\text { eso permitió que no estuviéramos desamparados. } \\
\text { La organización nos ayudó en esos momentos, y ya después cuando } \\
\text { yo me convertí en dirigente de igual manera. Hay mucha } \\
\text { vulnerabilidad para las mujeres campesinas en Colombia, sobre todo } \\
\text { porque la Colombia profunda pasa por muchas cosas que jamás salen } \\
\text { a la luz, no se imaginan las cosas que les hacen a las mujeres jóvenes, } \\
\text { todo ese dolor que se siente, las mujeres mayores porque no pueden } \\
\text { defender a sus hijas, y además porque es muy difícil denunciar, da } \\
\text { miedo denunciar. El día que las mujeres dejemos de sentir miedo } \\
\text { podemos avanzar, pero no sentir miedo es difícil, cuando se viola a } \\
\text { alguna mujer es difícil la denuncia dependiendo de donde viene la } \\
\text { violación. } \\
\text { Si viene de las FF.MM. es una sentencia la denuncia, y cosas así, } \\
\text { entonces estamos en una situación muy difícil particularmente porque } \\
\text { somos mujeres campesinas y es en el campo donde se da la guerra. } \\
\text { Lo quico nos da fortaleza y de seguir resistiendo es la }\end{array}$ \\
\hline
\end{tabular}




\begin{tabular}{|c|c|}
\hline & $\begin{array}{l}\text { organización, seguir nosotras, encontrarnos nosotras, seguir en medio } \\
\text { de todo esto buscando nuestros espacios para desahogarnos, } \\
\text { aprender, estudiar y todo eso nos ayuda a tener un caparazón que } \\
\text { permite que sigamos con nuestras banderas de lucha, seguir luchando } \\
\text { y construyendo, apoyando la economía campesina, fortaleciendo las } \\
\text { familias campesinas y las organizaciones. }\end{array}$ \\
\hline $\begin{array}{l}\text { Sofía Márquez } \\
\text { Oriunda del departamento de } \\
\text { Sucre y Criada en los Montes } \\
\text { de María, presidenta del } \\
\text { Sindicato del Departamento de } \\
\text { Sucre. }\end{array}$ & $\begin{array}{l}\text { Uno siempre hace memoria de la lucha y donde nací con mi padre y } \\
\text { mi madre, tengo claro que fue ese primer inicio de la inquietud, luego } \\
\text { en la escuela y ahí se va conociendo a varias personas que le dan a } \\
\text { uno el inicio de formación, liderazgo, información, ir a los talleres, } \\
\text { de hacer escuela política, sindical, ahí empezó mi formación, en ese } \\
\text { inicio, en mi hogar con mis padres y luego la escuela como ese } \\
\text { segundo paso y luego ya nuestra gran FENSUAGRO, nuestra lucha } \\
\text { y esperanza que es para nosotros FENSUAGRO, una escuela, un paso } \\
\text { muy importante. Así se dieron esos inicios y desde FENSUAGRO he } \\
\text { estado en actividades locales departamentales, regionales, nacionales } \\
\text { e internacionales y no fue algo que nació de ayer, esto ya hace unos } \\
27 \text { años que estoy en esta lucha de formación permanente, } \\
\text { coordinando con otras compañeras experiencias de otros procesos a } \\
\text { nivel nacional e internacional como la CLOC, la Vía Campesina, } \\
\text { entonces no ha sido fácil en medio de una sociedad tan machista y } \\
\text { convulsionada, y por otro lado todos los señalamientos y } \\
\text { persecuciones y las no garantías de un Estado Social de Derecho, es }\end{array}$ \\
\hline
\end{tabular}




\begin{tabular}{|c|c|}
\hline & $\begin{array}{l}\text { una doble lucha; pero ahí feliz, mi lucha mi convicción me ha llevado } \\
\text { a espacios muy importantes: ser candidata a la cámara de } \\
\text { representantes por la UP, a la asamblea de Sucre por la UP, entonces } \\
\text { hay una cosecha de la lucha, de la esperanza en medio de la } \\
\text { desesperanza que se vive y hoy más que nunca en el pueblo } \\
\text { colombiano. }\end{array}$ \\
\hline $\begin{array}{l}\text { Yira del Carmen Díaz } \\
\text { Nacida en Sucre, hija de padres } \\
\text { campesinos, siendo el ejemplo } \\
\text { de éstos lo que despierta el } \\
\text { deseo de defender los derechos } \\
\text { humanos. }\end{array}$ & $\begin{array}{l}\text { No sé si estaría aquí si mi mamá no estuviera de por medio, porque } \\
\text { las mujeres cargan con sus hijos y eso obliga que vayamos a las } \\
\text { reuniones. Yo inicié a los } 15 \text { como te digo, yo tenía oportunidades de } \\
\text { estar en Bogotá porque mis papas viajaban mucho y empecé a ayudar } \\
\text { con listas, inscripción, repartir cartillas, organizar mesas y entonces } \\
\text { fui buscando el tema de mujeres. Allí ese acumulado simbólico } \\
\text { permitió que me dimensionara en estar dentro de FENSUAGRO, con } \\
\text { las compañeras del ejecutivo nacional y antes del } 2015 \text {, como en el } \\
2013 \text { quede como delegada a la junta nacional de FENSUAGRO, } \\
\text { compuesta por organizaciones de base a nivel nacional y } \\
\text { FENSUAGRO tiene presencia en } 23 \text { departamentos, entonces mi } \\
\text { organización, de Sucre, me delegó para la junta nacional por ser } \\
\text { mujer y juventud, tenía esa doble condición en la junta. Quede en el } \\
\text { equipo nacional de mujeres, de ahí se desprenden las dinámicas de } \\
\text { cada junta, congreso y las líneas generales de trabajo, de acción. } \\
\text { Luego estuve en la secretaria de mujer, en el equipo de educación, de }\end{array}$ \\
\hline
\end{tabular}




\begin{tabular}{|c|c|}
\hline & $\begin{array}{l}\text { formación y eso me permitió hacer parte de las actividades } \\
\text { departamentales. }\end{array}$ \\
\hline $\begin{array}{l}\text { Aidé Moreno Ibagué } \\
\text { Lideresa campesina miembro } \\
\text { del Sindicato Agrario del Meta. } \\
\text { Su hermano líder social fue } \\
\text { asesinado en el año } 2020 \text { (Omar } \\
\text { Moreno Ibague). }\end{array}$ & $\begin{array}{l}\text { Yo nací en el campo, crecí al lado de padres campesinos ambos eran } \\
\text { del Sindicato agrario; entonces cuando llegué a FENSUAGRO tenía } \\
\text { recorrido en el cual yo hoy soy miembro del sindicato del que mis } \\
\text { padres fueron miembros, prácticamente lo fundaron, entonces para } \\
\text { mí no fue difícil, pero llegar a un proceso nacional como } \\
\text { FENSUAGRO es muy diferente al trabajo que hacía más regional, } \\
\text { me permitió conocer mucho más el país, la situación que no solo era } \\
\text { del Departamento sino del país, la situación de los campesinos, la } \\
\text { estigmatización a organizaciones agrarias, entonces llegando a la } \\
\text { federación, es un trabajo más grande a nivel nacional e internacional. }\end{array}$ \\
\hline $\begin{array}{l}\text { María Eugenia Valencia } \\
\text { Lideresa de la organización } \\
\text { sindical y actualmente activa en } \\
\text { los procesos de la agroindustria } \\
\text { de la región bananera del } \\
\text { Urabá. }\end{array}$ & $\begin{array}{l}\text { Yo empecé a involucrarme por la insatisfacción del sindicato al que } \\
\text { pertenencia, pues era diferente, un sindicato de mucha trayectoria } \\
\text { pero vimos algunos compañeros trabajadores de la agroindustria del } \\
\text { sector bananero que no nos sentíamos representados en ese sindicato; } \\
\text { entonces ahí tomamos la decisión para hacer otro sindicato para } \\
\text { luchar por nuestros derechos e ideales y vivir la experiencia, porque } \\
\text { teníamos insatisfacción, rabia, inconformidad, de ver que el sindicato } \\
\text { en el que estábamos en vez de defender nuestros derechos, defendía } \\
\text { a los empresarios. Vimos esa falencia y tomamos la decisión de } \\
\text { conformar el sindicato al que hoy pertenezco, que se llama }\end{array}$ \\
\hline
\end{tabular}




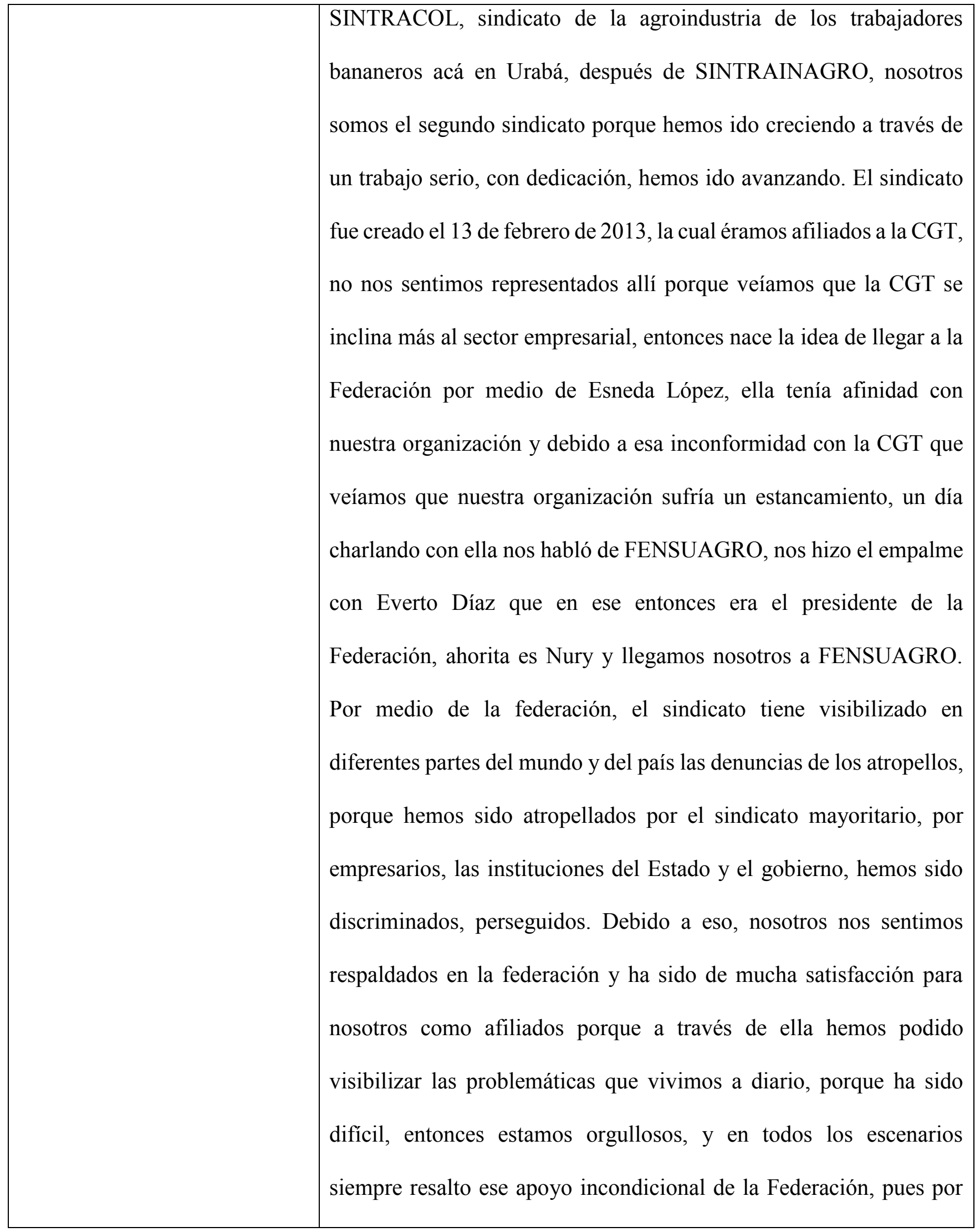




\begin{tabular}{|l|l|}
\hline & $\begin{array}{l}\text { ese apoyo hemos avanzado y hemos crecido y somos reconocidos a } \\
\text { nivel internacional. }\end{array}$ \\
\hline
\end{tabular}

Fuente: elaboración propia con base en las entrevistas realizadas.

Sin embargo, es importante señalar la dificultad que conlleva ser mujer y campesina, en una organización donde cultural y tradicionalmente los dirigentes han sido hombres quienes por su crianza han desarrollado una visión de la mujer como ama de casa, sumisa y que debe encargarse de la crianza de los hijos. El hecho de que hoy en día FENSUAGRO sea presidida por una mujer, luego de más de tres décadas de existencia, es muestra fehaciente de que el posicionamiento femenino no sólo es necesario, sino que ha tenido que luchar contra la reproducción de estructuras machistas y patriarcales que en muchos casos pretenden cerrarle los espacios de decisión, liderazgo y participación a las mujeres campesinas.

A continuación, se presenta una codificación que parte del análisis de las entrevistas realizadas, en donde se identifica al machismo como un problema estructural que limita la participación de las mujeres campesinas.

\section{Tabla 9. Machismo como elemento limitante de la participación política}

\begin{tabular}{|l|l|}
\hline Líder & Sobre el machismo \\
\hline Lorena Sánchez & $\begin{array}{l}\text { Las mujeres que participábamos éramos muy pocas, empezamos dos } \\
\text { mujeres y siempre fuimos tenidas en cuenta para el tema de la } \\
\text { secretaria, servir tinto, recoger sillas, limpiar el salón y no estábamos }\end{array}$ \\
\hline
\end{tabular}




\begin{tabular}{|c|c|}
\hline & $\begin{array}{l}\text { involucradas en las discusiones políticas de fondo, era un temor de } \\
\text { hablar porque en la cultura campesina está muy arraigado el } \\
\text { machismo y una mujer en el campo era muy sorpresivo liderando una } \\
\text { JAC o una organización agraria, porque el que manda es el varón, el } \\
\text { señor. }\end{array}$ \\
\hline Maidani Salcedo & No se presenta en este caso \\
\hline Nury Martínez & $\begin{array}{l}\text { Las mujeres líderes en el campo somos mujeres que nos dicen muy } \\
\text { duras, fuertes, pero yo creo que para hacer eso tenemos que ser } \\
\text { fuertes, porque debemos pasar por el machismo del hogar, tenemos } \\
\text { que pasar por encima de eso, en la organización es hasta peor, porque } \\
\text { es lo que dice el compañero y no la compañera, y al interior de la } \\
\text { misma dirección hay mucho recelo, en vez de respetar a las mujeres, } \\
\text { los hombres sienten celos y como nosotras somos muy entregadas al } \\
\text { trabajo sin importar los sacrificios, porque lo hacemos porque nos } \\
\text { gusta, entonces eso no les gusta. }\end{array}$ \\
\hline Sofía Márquez & $\begin{array}{l}\text { Desde FENSUAGRO he estado en actividades locales } \\
\text { departamentales, regionales, nacionales e internacionales y no fue } \\
\text { algo que nació de ayer, esto ya hace unos } 27 \text { años que estoy en esta } \\
\text { lucha de formación permanente, coordinando con otras compañeras } \\
\text { experiencias de otros procesos a nivel nacional e internacional como } \\
\text { la CLOC, la Vía Campesina, entonces no ha sido fácil en medio de } \\
\text { una sociedad tan machista y convulsionada. }\end{array}$ \\
\hline
\end{tabular}




\begin{tabular}{|l|l|}
\hline Yira del Carmen Díaz & No se presenta en este caso \\
\hline Aidé Moreno & $\begin{array}{l}\text { Para la mujer campesina hay otras prioridades, pero también está el } \\
\text { machismo, entonces la mujer está sujeta a que tiene que sacar el } \\
\text { permiso, no quiere decir que no, siempre hemos planteado que } \\
\text { debemos tener una buena relación con nuestros compañeros de vida, } \\
\text { pero la mujer campesina siempre está sujeta a pedir permiso, si el } \\
\text { esposo deja, si no, los niños, la casa, el marrano, la gallina, esas } \\
\text { prioridades hacen que la mujer no se vincule de tal manera. }\end{array}$ \\
\hline María Eugenia Valencia & \begin{tabular}{l} 
No se presenta en este caso \\
\hline
\end{tabular} \\
\hline
\end{tabular}

Fuente: elaboración propia con base en las entrevistas realizadas.

Como se puede evidenciar en la tabla anterior, el machismo es un elemento cuya tendencia se repite y contra el que las mujeres campesinas pertenecientes a FENSUAGRO luchan constantemente. Es importante resaltar que la condición de ser mujer y ser campesina, como se ha mencionado a lo largo de este documento, tiene diferentes connotaciones. En ese sentido, no sólo se enfrentan a una estructura eminentemente patriarcal, dominada por el patrón y el hombre quien toma las riendas de la vida familiar, sino también el ser campesina significa una relación intrínseca con la tierra. Por tal razón, características como el uso, ocupación y tenencia, sumados a la reducción de escenarios de participación, hacen de las lideresas de FENSUAGRO unas actrices en doble resistencia: contra el machismo estructural y contra las condiciones materiales de existencia producto de la implementación de unas políticas que empobrecen, despojan y desplazan a las familias rurales. 
El rol de la mujer ha ido evolucionando, tiempo atrás ha estado relacionada con el trabajo agrario y a su vez, ejerciendo un rol reproductivo y dependiente de la familia. Poco a poco estos roles se han ido transformando hasta llegar un modelo más igualitario en el que la mujer rural, sobre todo las jóvenes han tenido otro tipo de aspiraciones, buscar otro empleo que no sea el agrario, mudarse a la ciudad y no limitarse al hogar y a la familia sino más hacia metas individuales y de autonomía personal (Santos Zarco, 2019, p. 15).

Por tal razón, el concepto de mujer campesina toma un papel fundamental y preponderante en la lucha de las lideresas de FENSUAGRO. Frente a este proceso de reconocimiento y resignificación identitaria, las entrevistadas establecen diferentes criterios.

\section{Tabla 10. Ser mujer campesina}

\begin{tabular}{|l|l|}
\hline Lideresas & Mujer campesina \\
\hline Lorena Sánchez & $\begin{array}{l}\text { Ser mujer campesina es encarnar una cultura y una historia, es } \\
\text { recoger todo el legado de todos estos procesos organizativos, recoger } \\
\text { el sentimiento callado de un pueblo que ha caminado, ha luchado y } \\
\text { sigue luchando y resistiendo para que sea reconocido políticamente. }\end{array}$ \\
\hline Maidani Salcedo & $\begin{array}{l}\text { Es un honor, es muchísimo, significa poder trabajar para nuestro } \\
\text { sustento, en el campo es un honor, un orgullo ser mujer campesina y } \\
\text { labradora de la madre tierra que nos da nuestros productos, así como } \\
\text { nosotras parimos, la madre tierra nos pare el sustento, nos da la } \\
\text { comida. }\end{array}$ \\
\hline
\end{tabular}




\begin{tabular}{|c|c|}
\hline Nury Martínez & $\begin{array}{l}\text { Nosotros las mujeres somos muy buenas para sobresalir, nuestras } \\
\text { opiniones se visibilizan, pero en el campo es muy difícil, a veces } \\
\text { siente uno que lo anulan por completo. En mi caso en este momento } \\
\text { soy la presidenta de FENSUAGRO y de una organización que tiene } \\
43 \text { años que nunca había tenido una presidenta, eso no ha sido fácil, } \\
\text { ya llevo un año y en este momento hay más aceptación de los } \\
\text { compañeros, pero al principio no fue fácil, no de todos, sobre todo } \\
\text { por los jóvenes, pero a los mayores si les cuesta aceptar el liderazgo } \\
\text { de las mujeres. }\end{array}$ \\
\hline Sofía Márquez & $\begin{array}{l}\text { Una mujer campesina es una mujer llena de valores, de principios } \\
\text { intachables, de su identidad, de defensa de su integridad, en la lucha } \\
\text { por ese reconocimiento a la igualdad en términos políticos y sociales, } \\
\text { eso es una mujer campesina y eso es lo que pienso desde mi ser, mi } \\
\text { convicción y experiencia, mujeres que luchamos por la dignificación } \\
\text { de la mujer y ese reconocimiento de nuestros derechos. }\end{array}$ \\
\hline Yira del Carmen Díaz & $\begin{array}{l}\text { Enarbola la lucha de las mujeres trabajadoras del campo en } \\
\text { Colombia, porque se invisibiliza, lo que se hace no se ve socialmente, } \\
\text { no se tiene en cuenta, no se valora, pero es una lucha, es toda una } \\
\text { construcción porque siempre hemos estado arraigadas a la } \\
\text { construcción de lo que es la soberanía alimentaria, siempre está } \\
\text { marcado en la mujer campesina el cuidado del hogar, esa lucha y ese } \\
\text { hacer, entonces se tejen un par de construcciones allí. Sobre todo, }\end{array}$ \\
\hline
\end{tabular}




\begin{tabular}{|c|c|}
\hline & $\begin{array}{l}\text { creo que las mujeres campesinas organizadas permiten tener otro } \\
\text { tejido social, desde lo individual hacia lo colectivo, de lo privado a lo } \\
\text { público. }\end{array}$ \\
\hline Aidé Moreno & $\begin{array}{l}\text { Ha sido lo más importante que me ha podido pasar en la vida, ser de } \\
\text { familia campesina, haber crecido en el campo, tener contacto con el } \\
\text { sector rural, es lo más grandioso. }\end{array}$ \\
\hline María Eugenia Valencia & $\begin{array}{l}\text { Ser mujer campesina es mucho, yo considero que la mujer campesina } \\
\text { es muy importante en la sociedad porque nosotras somos las que } \\
\text { producimos alimento para el sostenimiento de la familia, de la región, } \\
\text { del municipio, a nivel nacional e internacional porque en el caso en } \\
\text { el que yo trabajo, que es el sector del banano tiene que ver con la } \\
\text { agroindustria y exportamos banano a nivel mundial, porque el banano } \\
\text { del Urabá es exportado para diferentes países, entonces considero que } \\
\text { somos importantes como mujeres campesinas porque impulsamos el } \\
\text { producto que trabajamos con nuestras manos, nuestro esfuerzo, lo } \\
\text { impulsamos para que muchas personas se beneficien, se alimenten. }\end{array}$ \\
\hline
\end{tabular}

Fuente: elaboración propia

Como se puede observar, el ser mujer campesina es una doble condición que las líderes entrevistadas asumen. No sólo se es mujer luchando de manera organizada dentro de un sindicato agrario contra las estructuras machistas de poder y el dominio sobre ellas y sus vidas, sino además el ser campesinas las hace figuras de la resistencia contra la violencia, las 
políticas de despojo y la supresión de prácticas como la agricultura familiar y campesina, la agroecología y la defensa de los territorios.

Así pues, como se mencionaba anteriormente, la mujer en Colombia se convirtió en un botín de guerra, pero además en la vanguardia de la resistencia contra la violencia. El ser campesina en Colombia es considerado no sólo una condición que promueve la exclusión, sino que además promueve la victimización, pues la gran mayoría de personas desplazadas por la violencia que debieron reconstruir sus hogares fueron mujeres. No es una sorpresa que la gran mayoría de lideresas entrevistadas sean madres cabeza de familia.

De esta manera, el ser mujer campesina hace parte de un grupo social que se mantiene en una constante lucha contra la desaparición por cuenta de la violencia estructural, las políticas que profundizan el neoliberalismo y la violencia. Además, protege y defiende la economía campesina y apuesta a alternativas agroecológicas. La identidad en ese sentido, se convierte en elemento transversal de la consolidación del ejercicio de liderazgo de la mujer campesina al interior de FENSUAGRO:

La sociedad establece los medios para categorizar a las personas y el complemento de atributos que se perciben como corrientes y naturales en los miembros de cada una de esas categorías. El medio social establece las categorías de personas que en él se pueden encontrar. E1 intercambio social rutinario en medios preestablecidos nos permite tratar con "otros" previstos sin necesidad de dedicarles una atención o reflexión especial (Goffman y Guinsberg, 1970, p. 1).

De igual manera, como afirma Eric Hobsbawm: 
La «pertenencia» a algún grupo humano, prescindiendo ahora de relaciones tales como los lazos biológicos que unen a las madres con sus hijos, es siempre una cuestión de contexto y definición social, por lo general negativa —es decir, se especifica la condición de miembro del grupo por exclusión- (Hobsbawm, 1994, p.1).

Así pues, el hecho de pertenecer a un género, en este caso ser mujer, y de pertenecer a un grupo social cuyas características sociales, económicas y políticas las convierte en campesinas, las hace doblemente subordinadas. Por un lado, son en su mayoría madres cabeza de familia, quienes mantienen su hogar, y, por otro lado, comprenden y entienden su rol dentro de las formas y modos de producción, es decir múltiples identidades de género y clases. Ahora bien, esto mismo podemos evidenciarlo en los estudios realizados desde la perspectiva Interseccional donde la participación de la mujer en la sociedad a lo largo de la historia, ha sido enmarcada en su rol netamente reproductivo y sexual. De esta manera en la invisibilidad y en el desplazamiento a la condición de sexualidad y reproducción, la sociedad patriarcal dispuso fronteras invisibles para mantener las líneas divisorias entre el hombre y la mujer. Resulta pertinente entonces entender los factores que permearon el proceso histórico para que las mujeres fueran relegadas desde su posicionamiento social a estados de subordinación. A su vez se hace relevante estudiar el camino recorrido por las mismas para nuevamente posicionarse en su condición de dignidad y empoderamiento social.

Hacer un estudio basado en los entretejidos históricos que muestran los procesos recorridos por la mujer desde las categorías, sexual, reproductiva, género y raza, es importante para entender los procesos actuales y los avances de las políticas de 
empoderamiento de la mujer en la sociedad. A lo largo de la historia el hombre ha desarrollado diversos métodos de subordinación e inferiorización de la mujer; en Europa se consideró a la mujer desde lo sexual bajo la condición de máquina reproductora y productora de placer.

Las mujeres de la burguesía europea fueron excluidas de la esfera de la autoridad colectiva, de la producción del conocimiento y de toda posibilidad en los ámbitos de la vida. Se redujeron al acceso de los hombres de manera sexual obligatoria y reproductora de la clase, posición racial, colonial y raza (Lugones, 2008).

Con la colonización europea se inicia para América el despliegue y control de una política de sujeción, dominio e imposición jerárquica; un control en el manejo de las relaciones de poder que desvirtúa a la mujer desde su rol de líder, matriarca, participante de una sociedad ginecrática dentro de sus comunidades indígenas donde se resaltaban diferencias y aceptaciones de género lejos de basarse en lo biológico. La Colonialidad desconoce entonces las tradiciones, leyes y la cultura de los nativos imponiendo tradiciones y políticas nuevas que excluyen a la mujer en la política colonial y la descalificación de las mismas para roles de liderazgo, subordinándola en todos los aspectos, reemplazando la pluralidad espiritual ginecrática con un ser supremo masculino con el cual logra someter a las tribus.

Muchas comunidades tribales de Nativos Americanos eran matriarcales, reconocían positivamente tanto a la homosexualidad como al «tercer» género, y 
entendían al género en términos igualitarios, no en los términos de subordinación que el capitalismo eurocentrado les terminó por imponer (Lugones, 2008)

El trabajo de Gunn Allen nos permite ver que el alcance de las diferencias de género era mucho más abarcador y no se basaba en lo biológico. Los procesos coloniales en África también impactaron violentando a la mujer las cuales se resistieron a los cambios e imposiciones culturales, proceso apoyado por los hombres de las tribus los cuales apoyaron a los europeos en la exclusión y dominación de las anahembras.

El mismo proceso que las categorizó y redujo de hembras a «mujeres» las descalificó para roles de liderazgo. La emergencia de la mujer como una categoría reconocible, definida anatómicamente y subordinada al hombre en todo tipo de situación, resultó, en parte, de la imposición de un Estado colonial patriarcal. Para las mujeres, la colonización fue un proceso dual de inferiorización racial y subordinación de género (Lugones, 2008). La Colonialidad europea justifica y globaliza la violencia de género e inferiorización de la mujer desde la consideración del género como una imposición colonial, imposición de poder y dominación de raza.

Las opresiones sobre la mujer marcan un acontecer histórico que se ha ido desligando bajo el surgimiento de la rebelión feminista enmarcada en un principio América en la participación de las mujeres en las constituciones de las guerras, las cuales se reconocen como un tejido completo de raza, género, sexo y pensamiento, lo cual la lleva a emprender el camino de empoderamiento de su papel social, familiar, económico y político. 
En América Latina encontramos que el concepto de feminismo y sus diversas variables es utilizado para evidenciar las diferentes manifestaciones de exclusión social,

En “América Latina, así como en otras partes del Sur global, la inclusión de cuestiones de raza, clase y etnia en el género estaba bien desarrollada" (Vuola, 2012: $135)$.

Según Amy Conger Lind (citada por Vuola, 2002),

"es a través de la creación de una identidad colectiva que las mujeres latinoamericanas han llegado a adoptar una postura contra varias formas de poder representadas en su vida cotidiana" (p. 139).

Parte de esta colectivización ha surgido no solo por la influencia de la teoría feminista estadounidense o europea, sino también por los contextos políticos e históricos específicos de cada país, de la realidad territorial, así como por los discursos y prácticas de desarrollo.

Se observa entonces que la mujer busca la legitimación de su género por el cual ha sido invisibilizada por la masculinidad al grado de sexualizarla y desplazarla a la condición de reproductora sujeta a las labores del hogar, pero sin autoridad para contrarrestar los abusos con la legitimación del Estado.

La historia política ha actuado de cierta forma en el campo del género, porque éste es un campo que, aunque parezca estático, tiene un significado fluido. Si consideramos la diferencia entre lo masculino y lo femenino no como algo ya sabido sino como problemática, 
como algo que está siempre contextualmente definido, construido repetidamente, debemos entonces preguntarnos no sólo acerca de lo que está en juego en las proclamas y debates que invocan al género para explicar o justificar sus posiciones sino también acerca de las nociones implícitas sobre el género que se están invocando o apoyando.

En Colombia la interseccionalidad entrelaza varios sistemas de opresión, explotando toda la coexistencia de la misma, raza, color, clase, sexo, enmarcando a las mujeres por debajo de un Estado patriarcal violento que limita el desarrollo de éstas.

"creo que el término interseccionalidad puede usarse también en el contexto latinoamericano, si aclara y da estructura al menos algunas intenciones de teorizar sobre el género en el continente latinoamericano multiétnico y dividido en clases" (Vuola, 2012:139).

En las experiencias de la violencia y los testimonios de las mujeres afrodescendientes víctimas del conflicto, lo que se observa es una denuncia de una serie de violencias interrelacionadas: contra los cuerpos "territorializados", las familias, las comunidades, los “territorios de vida", la cultura, lo común, etc. No sólo la agresión sexual es violencia contra las mujeres. El despojo, la desposesión; la movilidad forzada -éxodos, desplazamiento interno y exilio transfronterizo- son procesos que golpean violentamente a las mujeres afrodescendientes -en sus espacialidades y vínculos con el «lugar» y en el tejido social de sus comunidades- a la vez que pronuncian la geografía de la desigualdad de un país marcado por la exclusión de la población afrodescendiente en su conjunto (Medina García 2018: 313). 
En el siglo XX la mujer abraza el feminismo y busca el posicionamiento del mismo en aras de encontrar su lugar en el mundo del cual ha venido siendo desplazada e ignorada; pretende identificarse y desarrollar pertenencia, cerrando brechas jerárquicas sociales, rompiendo barreras políticas de los estados opresores que bajo la globalización imponen el imperialismo cultural, dejando a su paso, conflictos de pobreza, abusos y violentización de las masas e invisibilización de la mujer. Reclamar derechos y posicionamiento requiere abordar espacios como la explotación del estado, abusos laborales, enmarcamiento a las tareas del hogar y opresión de mujeres contra mujeres.

En el caso del feminismo, el proyecto significa priorizar la lucha de género y muchas veces en estos procesos las feministas se olvidan de otras líneas divisorias y de otras luchas. Por tanto, es importante ser conscientes de las otras líneas divisorias de diferencia e identidad y de exclusión cuando estamos luchando en el frente feminista. La mujer busca protagonizar un cambio multicultural universal con prácticas y políticas globalizadas y trasnacionales; busca desdibujar las fronteras de la estigmatización, racismo y la subordinación.

Las mujeres de la clase trabajadora experimentan diferentes formas de estereotipos de género, prácticas de género diferentes, a las de la mayoría de las mujeres de clase media. $\mathrm{Al}$ comprenderse como tal, son mujeres que han tomado una iniciativa de resistencia contra las estructuras patriarcales propias del campo colombiano, y son campesinas que se reconocen como miembros de un grupo con características particulares que luchan por el acceso a la tierra y el reconocimiento como campesinas. Hay una combinación identitaria que conlleva necesariamente a mixturar las formas de acción, dirigidas hacia la acción colectiva de los movimientos agrarios y campesinos que hoy en día tienen grandes dirigentas femeninas y cuya base social y militante es en gran parte, de mujeres. 
De esta manera, la acción social ligada a los movimientos sociales de carácter campesino, se convierten en eje fundamental de la potencialización de los liderazgos femeninos que se disputan los escenarios de dirección y ejecución dentro de las mismas organizaciones. Luego de reconocerse como mujer y como campesina, inicia el proceso de reconocimiento como lideresa, en un contexto que se caracteriza por la masculinización de la actividad y la feminización de la inactividad laboral, y, en ese sentido, el grado de ruralidad acentúa esa brecha de género, que es mayor en las zonas rurales que en las urbanas. Así, la invisibilización de la perspectiva de género en el medio rural aparece como una forma de "violencia", que conlleva la exclusión de las mujeres del poder de tomar decisiones (Sánchez y Barral, 2019, p. 183).

Por tal razón, es de suma importancia reconocer los procesos de resistencia y organización, en tanto le aporta espacios de autorreconocimiento a las mujeres, además de reconocimiento a nivel veredal, barrial, local, regional, nacional e internacional, como muchas de ellas lo han afirmado. Es indudable que a pesar de la estructura machista presente y evidente en muchos escenarios, la capacidad organizativa de las mujeres campesinas ha adelantado la ruptura del paradigma bajo el cual se dinamizaban los roles de género en el campo.

Tabla 11. Ser mujer líder

\begin{tabular}{|l|l|}
\hline Lideresas & Mujer líder campesina \\
\hline
\end{tabular}




\begin{tabular}{|c|c|}
\hline Lorena Sánchez & $\begin{array}{l}\text { Ser líder campesina es una responsabilidad enorme, una } \\
\text { responsabilidad y compromiso con una lucha social, un legado y un } \\
\text { camino que tiene muchos obstáculos, ser líder campesina es } \\
\text { representar y ser la voz de una postura política y de un sentimiento } \\
\text { colectivo. Eso encierra ser líder campesina. }\end{array}$ \\
\hline Maidani Salcedo & $\begin{array}{l}\text { Virgen santa, bueno, no sé si es que uno nace con eso; somos muchas } \\
\text { compañeras que estamos en la junta directiva de la organización en } \\
\text { Piamonte y todos le metemos perrenque, verraquera, pero algunas les } \\
\text { dan más miedo que otras, a algunas nos da miedo y lo volvemos en } \\
\text { valor, es un desafío luchar por las demás personas. En Piamonte } \\
\text { tenemos } 700 \text { afiliados, y de esos agradecerán 100; entonces ser líder } \\
\text { campesina es duro, pero gratificante porque me gusta y me nace, } \\
\text { siento el respaldo de las comunidades, me siento bien, pero a veces } \\
\text { siento que se me va el aire porque es una de las organizaciones más } \\
\text { perseguidas; he sido muy amenazada, me han echado bala, han } \\
\text { desplazado mi familia, el } 17 \text { de diciembre del año pasado me dieron } \\
24 \text { horas para sacar a toda mi familia, el (cartel de) Sinaloa; creíamos } \\
\text { que con los acuerdos se podía vivir mejor pero ha sido difícil, le } \\
\text { quedó grande al gobierno. Pareciera que a ellos les gustara el } \\
\text { narcotráfico porque cuando uno impulsa los acuerdos de La Habana } \\
\text { es perseguido y estigmatizado, entonces es duro, es un desafío muy } \\
\text { grande. Lo único que me da fuerza es que cuento con el respaldo de } \\
\text { mi pareja, me respalda, aunque sienta miedo, pero no es el que critica, }\end{array}$ \\
\hline
\end{tabular}




\begin{tabular}{|c|c|}
\hline & $\begin{array}{l}\text { el que se va, él está pendiente de los quehaceres de la casa y la finca } \\
\text { mientras nosotros hacemos el trabajo. Me llegó el sentimentalismo. }\end{array}$ \\
\hline Nury Martínez & $\begin{array}{l}\text { Es mucho más difícil ser líder campesina que ser líder en la ciudad. } \\
\text { Nosotros las mujeres somos muy buenas para sobresalir, nuestras } \\
\text { opiniones se visibilizan, pero en el campo es muy difícil, a veces } \\
\text { siente uno que lo anulan por completo. Las mujeres líderes en el } \\
\text { campo somos mujeres que nos dicen muy duras, fuertes, pero yo creo } \\
\text { que para hacer eso tenemos que ser fuertes, porque debemos pasar } \\
\text { por el machismo del hogar, tenemos que pasar por encima de eso. En } \\
\text { la organización es hasta peor, porque es lo que dice el compañero y } \\
\text { no la compañera, y al interior de la misma dirección hay mucho } \\
\text { recelo, en vez de respetar a las mujeres, los hombres sienten celos y } \\
\text { como nosotras somos muy entregadas al trabajo sin importar los } \\
\text { sacrificios, porque lo hacemos porque nos gusta, entonces eso no les } \\
\text { gusta. En mi caso en este momento soy la presidenta de } \\
\text { FENSUAGRO y de una organización que tiene } 43 \text { años que nunca } \\
\text { había tenido una presidenta, eso no ha sido fácil, ya llevo un año y en } \\
\text { este momento hay más aceptación de los compañeros, pero al } \\
\text { principio no fue fácil, no de todos, sobre todo por los jóvenes, pero a } \\
\text { los mayores si les cuesta aceptar el liderazgo de las mujeres. }\end{array}$ \\
\hline Sofía Márquez & $\begin{array}{l}\text { Una mujer líder campesina es asumir unos riesgos, es atreverse en } \\
\text { medio de una sociedad tan convulsionada, que no garantiza ningún }\end{array}$ \\
\hline
\end{tabular}




\begin{tabular}{|c|c|}
\hline & $\begin{array}{l}\text { derecho o al menos no garantiza el derecho de las minorías, pero no } \\
\text { somos ninguna minoría, somos mayorías de todo el pueblo } \\
\text { colombiano. Eso es una mujer líder campesina, es capaz de asumir } \\
\text { un liderazgo, abandonándose ella en su ser, su existencia para } \\
\text { coordinar acciones de reconocimiento a otras mujeres líderes } \\
\text { también, reconocer a otras y más mujeres no solo campesinas, sino } \\
\text { también indígenas, citadinas, que sean capaces de reconocer sus } \\
\text { derechos, de reconocerse como mujer, sujetas políticas y no objetos } \\
\text { de hombres y de algunas mujeres que lastimosamente son mujeres y } \\
\text { no nos representan, una mujer lideresa es valiente, capaz para } \\
\text { coordinar acciones para el bien común para la gran mayoría. Esa } \\
\text { mujer lideresa que, con muy escasos recursos y estudios, sentimos la } \\
\text { lucha de que tenemos que coordinar acciones para que haya políticas } \\
\text { públicas que garanticen el derecho de nuestra existencia de las } \\
\text { mujeres campesinas, que reconozcan los aportes al desarrollo de todo } \\
\text { el pueblo, de toda la sociedad, eso es una mujer líder campesina para } \\
\text { mí. }\end{array}$ \\
\hline Yira del Carmen Díaz & $\begin{array}{l}\text { La lucha se hace doble, hay más que luchar, es asumir más } \\
\text { responsabilidades, no por cumplir, sino algo político, que no soy solo } \\
\text { yo, somos varias, muchas y hay que asumir con posturas políticas } \\
\text { organizativas, en buscar como nos tejemos entre nosotras, como nos } \\
\text { ayudamos para avanzar, para lograr lo que queremos, que no haya }\end{array}$ \\
\hline
\end{tabular}




\begin{tabular}{|c|c|}
\hline & $\begin{array}{l}\text { maltrato, pero que no haya maltrato en las organizaciones, dar esas } \\
\text { discusiones para formar como mujer. }\end{array}$ \\
\hline Aidé Moreno & $\begin{array}{l}\text { Es un espacio muy importante porque nos conecta con la realidad que } \\
\text { vive el país, segundo nos permite conocer las realidades del campo } \\
\text { rural (sic), la importancia del campo, los beneficios que brinda el } \\
\text { campo y que pocas personas se dan cuenta de lo importante que son } \\
\text { los importantes en esos territorios. }\end{array}$ \\
\hline María Eugenia Valencia & $\begin{array}{l}\text { Es visualizar y compartir las diferentes inquietudes inconformidades } \\
\text { que haya en la comunidad, las dificultades que tengamos y buscar los } \\
\text { mecanismos de que nuestro trabajo como líder campesino sea } \\
\text { visualizado, porque la verdad es que el campo no solamente en el país } \\
\text { sino me atrevería a decir en el mundo, no es tenido en cuenta, no se } \\
\text { le da esa importancia. Que los gobiernos de diferentes países del } \\
\text { mundo deben darle al sector campesino. El liderazgo campesino es } \\
\text { impulsar ideas, capacitar a las compañeras, brindarles una } \\
\text { orientación, apoyarlas en las inquietudes e ideas que salgan de ellas } \\
\text { mismas, compartir y analizar esas inquietudes que tengamos como } \\
\text { campesinas, ese es el liderazgo campesino. Recoger la inquietud de } \\
\text { cada una de las compañeras y que esas inquietudes e inconformidades } \\
\text { sean conocidas, que se conozcan en diferentes lugar y escenarios } \\
\text { todas las problemáticas que vivimos en el campo. }\end{array}$ \\
\hline
\end{tabular}

Fuente: elaboración propia. 
La condición de las mujeres líderes en FENSUAGRO es de triple hélice: son mujeres que luchan contra el machismo fuera y dentro de la organización, son mujeres campesinas que luchan contra el despojo y lideresas que corren peligro y luchan contra los asesinatos selectivos de ellas y de sus compañeros y familia. Esta triada en muchas ocasiones se ha convertido en una sentencia de muerte para quienes han asumido responsabilidades organizativas, de defensa del territorio la vida y la lucha por los derechos de las campesinas.

Las mujeres rurales enfrentan todos los días desigualdades concretas y con diferentes características. Una de ellas es la dificultad en el acceso a derechos que tienen las mujeres en comparación a los hombres. Otros puntos son los impactos diferenciados provocados por un patriarcado estructural y el avance cada vez mayor de los agro negocios y las industrias extractivas sobre los territorios (Ramos y Drago, 2013).

Sin embargo, a pesar de los peligros que conlleva la triada Mujer, mujer-campesinalideresa, es innegable que el hecho de pertenecer a una organización que les amplía su formación política, lo que les permite cuestionarse no sólo las relaciones de poder a nivel familiar y veredal, sino los impactos de las políticas rurales neoliberales, hace de la organización y la acción colectiva un generador de empoderamiento. La acción social de las mujeres campesinas, entendida como la situación “donde el sentido mentado por su sujeto o sujetos está referido a la conducta de otros, orientándose por ésta en su desarrollo" (Weber, 1996, p.5), se condensa en el movimiento social campesino y la organización social reconocida como FENSUAGRO. Esto genera amplios procesos de empoderamiento y de disputa de los escenarios políticos, sociales, económicos y culturales, prueba de esto es el actual liderazgo como presidenta de la mujer campesina y lideresa Nury. 
El empoderamiento en la mujer permite que se estimule una participación social activa que le lleva a experimentar un desarrollo positivo de su auto concepto, en términos de atributos como competencia, madurez emocional, confianza en sí misma, persistencia, empatía y coraje (Singer et ál., 2002, en: Erazo, Jiménez y López, 2014, p. 115).

Tabla 12. Empoderamiento de las mujeres líderes campesinas de FENSUAGRO

\begin{tabular}{|l|l|}
\hline Líder & $\begin{array}{l}\text { Empoderamiento producto de la organización y la acción colectiva } \\
\text { Lorena Sánchez }\end{array}$ \\
$\begin{array}{l}\text { Empezar a entender mi papel como mujer y como constructora de una } \\
\text { delegada de mujer campesina, en la Coordinadora Latinoamericana } \\
\text { de organizaciones del Campo, CLOC, en diferentes países y entendí } \\
\text { que era una lucha mundial, sin fronteras donde podía identificarme y } \\
\text { emancipar esos sueños que en un momento veía imposibles, y cuando } \\
\text { se tiene claro el objetivo, el por qué se lucha, la claridad política que } \\
\text { es una necesidad, de luchar por educación, que reconozcan al } \\
\text { campesino como un actor de derechos, entonces FENSUAGRO hizo } \\
\text { parte de mi liderazgo el 70\% en lo que es la formación de conciencia } \\
\text { y teórico-práctica. Con FENSUAGRO me aventuré a dar un discurso } \\
\text { en Ecuador a 2.000 personas, catapulté mi liderazgo que de pronto en } \\
\text { el campo la estigmatización, el miedo, el señalamiento y el machismo }\end{array}$ \\
\hline
\end{tabular}




\begin{tabular}{|c|c|}
\hline & $\begin{array}{l}\text { no se da, y me fue ayudando ese gran potencial y acumulado que no } \\
\text { sabía que tenía. }\end{array}$ \\
\hline Maidani Salcedo & $\begin{array}{l}\text { Aprendí y conocí más, era muy tímida, y me dio más fuerza tener la } \\
\text { formación, se adquieren conocimientos y experiencia, porque nuestra } \\
\text { federación es el respaldo de la base. Pero que la federación diga que } \\
\text { les vamos a dar un apoyo o algo no, porque a mí personalmente me } \\
\text { gustaría que la federación tuviera apoyo psicológico, económico para } \\
\text { cuando uno tiene que huir del territorio porque la policía dijo que me } \\
\text { iban a matar, me sacan de Piamonte en un operativo del ejército, la } \\
\text { policía, la Unidad Nacional de Protección, UNP, se arma la de Troya, } \\
\text { ya no puedo andar sola, estoy en una camioneta con escoltas, pierde } \\
\text { la privacidad, pierde la vida uno, a veces se siente uno como mujer } \\
\text { asfixiado, pero siempre he contado con Nury y Aidé, pero me hubiera } \\
\text { gustado tener otras herramientas, que la federación dé las } \\
\text { herramientas para que otras compañeras no vivan lo que yo, porque } \\
\text { es muy duro, es inexplicable, se siente impotente, se desbarata el } \\
\text { mundo sabiendo que los burgueses y el capitalismo nos absorbe a } \\
\text { quienes queremos un país con justicia social, nos ven mal, nos } \\
\text { persiguen, cuando nosotros no somos de grupos armados, sino que } \\
\text { pensamos en los territorios, que sean diferentes. }\end{array}$ \\
\hline Nury Martínez & $\begin{array}{l}\text { Para mí ha aportado todo lo que soy, porque no llegué a } \\
\text { FENSUAGRO de adulta, sino desde muy niña y he estado todo el }\end{array}$ \\
\hline
\end{tabular}




\begin{tabular}{|c|c|}
\hline & $\begin{array}{l}\text { tiempo en mi organización de base, luego en los espacios nacionales, } \\
\text { internacionales, que me han permitido conocer otras experiencias, } \\
\text { conocer otras mujeres, ser una dirigente formadora, me formó y } \\
\text { formó. Me siento como un referente para otras mujeres, porque hay } \\
\text { muchas que dicen que las primeras cosas que aprendieron de todo } \\
\text { esto fue de la compañera Nury, y todo eso lo facilitó FENSUAGRO, } \\
\text { porque me dieron responsabilidades y me desafiaron y saqué cosas } \\
\text { que no sabía que tenía; y liderar las escuelas, ser facilitadora han sido } \\
\text { espacios muy importantes, y claro también hay momentos donde las } \\
\text { cosas son difíciles y es ahí donde uno saca esa casta de liderazgo, y } \\
\text { ese reconocimiento nacional e internacional, con la CLOC y la Vía } \\
\text { Campesina, es por lo que hemos hecho desde las bases, no me } \\
\text { imagino la vida sin FENSUAGRO. }\end{array}$ \\
\hline Sofía Márquez & $\begin{array}{l}\text { FENSUAGRO fue súper clave en mí, hace un aporte súper valiosa } \\
\text { porque me ayuda al rescate de la conciencia de clase, a identificar mi } \\
\text { estrato social, de manera que no haya equivocación para reconocerme } \\
\text { como campesina y mujer, la formación de FENSUAGRO ha sido } \\
\text { muy valiosa para reafirmarme como mujer campesina y defender mi } \\
\text { identidad, buscar esa lucha por el reconocimiento del campesinado } \\
\text { como sujeto político de derechos; entonces desde la formación, la } \\
\text { educación que FENSUAGRO brinda a sus afiliados, a sus líderes, es } \\
\text { el aporte que FENSUAGRO hace en este caso conmigo. Y } \\
\text { comprender los momentos que ha tenido el pueblo, lo que ha pasado }\end{array}$ \\
\hline
\end{tabular}




\begin{tabular}{|l|l|}
\hline YENSUAGRO, la formación permanente desde el departamento de \\
educación y organizativo es muy importante.
\end{tabular}




\begin{tabular}{|c|c|}
\hline & $\begin{array}{l}\text { como mujer capaz de liderar y de ayudar en estos procesos; ya } \\
\text { FENSUAGRO ahí tiene un papel protagónico, pues nosotras las } \\
\text { mujeres tenemos dificultades en esa organización, sobre todo en el } \\
\text { campo las mujeres no nos vinculamos fácil a los procesos porque hay } \\
\text { otras prioridades, para la mujer campesina hay otras prioridades. }\end{array}$ \\
\hline María Eugenia Valencia & $\begin{array}{l}\text { Ha sido difícil, no es fácil liderar diferentes procesos porque soy } \\
\text { madre cabeza de familia, tengo una responsabilidad con la familia y } \\
\text { eso genera dificultades en la familia, porque a uno le toca estar acá, } \\
\text { allá, volteando y la familia se cansa y ellos reclaman porque uno no } \\
\text { pasa tiempo con ellos, por la organización, que mantiene viajando, en } \\
\text { reuniones, pero poco a poco los he ido concientizando de que es } \\
\text { necesario. Yo tengo } 55 \text { años y siempre me han molestado las } \\
\text { injusticias, y después de tantos años cuando los hijos están más } \\
\text { grandes, eso ha permitido que yo haya llegado a esos escenarios, uno } \\
\text { como mujer debe tratar de hacer parte de esos escenarios porque ahí } \\
\text { uno puede expresarse, dar sus aportes, ser crítico, eso ha sido en lo } \\
\text { personal, dificultades muchas, económicas, porque a veces por estar } \\
\text { en escenarios uno no va a laborar, a trabajar, entonces han sido } \\
\text { muchas barreras para estar donde estoy y también es de resaltar que } \\
\text { he adquirido mucho conocimiento, defender mis derechos, de mis } \\
\text { compañeros, orientarlos, guiarlos a través del conocimiento que } \\
\text { hemos adquirido en FENSUAGRO, porque la federación se enfoca } \\
\text { en formar y fortalecer para que crezcamos y sepamos defender }\end{array}$ \\
\hline
\end{tabular}




\begin{tabular}{|l|l|}
\hline nuestros ideales. Acá somos muchas madres de familia, en todos los \\
escenarios esa es la parte que más resalto, a nosotras nos han matado \\
hijos, hermanos, todo, debido a la violencia, eso ha sido muy difícil, \\
duro, en el Urabá hemos sido las más sufridas y sacrificadas, por \\
todas las olas de la violencia en el país nosotras hemos sido las más \\
perjudicadas.
\end{tabular}

Fuente: elaboración propia

Como se puede observar en los testimonios de las lideresas entrevistadas, FENSUAGRO ha significado una oportunidad de formación, resignificación y reconocimiento. De igual manera, ha permitido potenciar las aptitudes de líderes que muchas de las mujeres poseen y que por las estructuras patriarcales mencionadas con anterioridad no habían podido salir a flote: el concepto de empoderamiento está ligado al concepto de liderazgo. Según Gibson y Donnelly (2001), los líderes son agentes de cambio, personas cuyos actos afectan a otras personas más que los propios actos de estas. El liderazgo ocurre cuando un miembro del grupo modifica la motivación o las competencias de otros en el grupo (Erazo, Jiménez y López, 2014, p.152).

Junto con el empoderamiento y el liderazgo, las mujeres pertenecientes a FENSUAGRO han encontrado las herramientas no sólo para tomar las riendas de su vida y de su actividad política, sino que han forjado redes comunitarias de apoyo y tejido social. El desarrollo local y la gestión y autogestión promovidas desde el seno de la organización que ellas construyen diariamente se convierte en un horizonte político, la triple hélice MLC no 
sólo amplía su espectro y campo de acción, sino que además las dota de capital simbólico que permite impactar de manera mucho más contundente a nivel local, regional y nacional.

A su vez, el hecho de que muchas de las lideresas reconozcan que la participación política en FENSUAGRO les ha dado nuevas perspectivas, permite incluso hablar de una nueva formación de escala de valores, una reconfiguración de la cosmovisión de la mujer que trasciende a ser lideresa y que se reconoce como sujeta de derechos por ser precisamente mujer y además por ocupar un papel fundamental en la protección de las formas de vida, en la seguridad y soberanía alimentaria.

\section{Mapa 6. Palabras que asomaban en las entrevistas a MCL}

A lo largo de las entrevistas realizadas, se destacaron palabras relevantes desde la cosmovisión, en el lenguaje de las mujeres campesinas

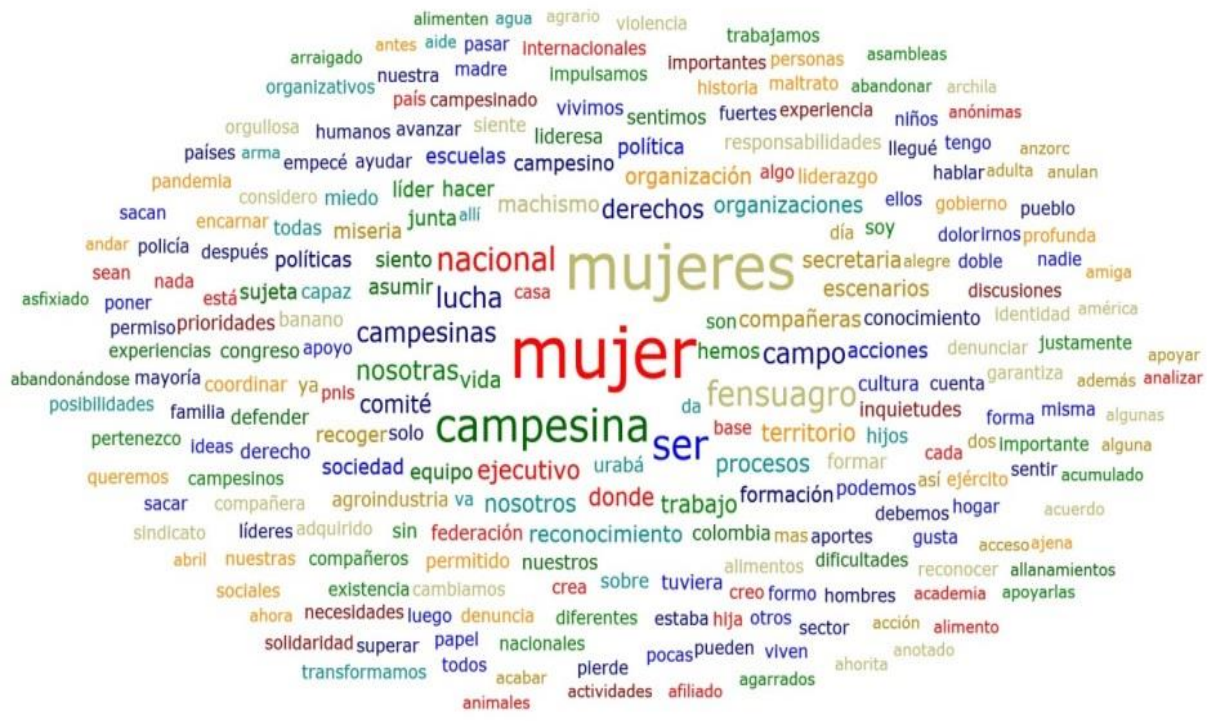

Fuente: elaboración propia con base en AtlasTi. 
Las MLC de FENSUAGRO no sólo reivindican derechos de género, sexuales y reproductivos, reivindican su papel protagónico en la lucha por los derechos frente al uso, ocupación y tenencia de la tierra, expresan sus identidades como campesinas pues de la tierra vienen y su herencia es el campo. "Lejos de ser un reclamo anacrónico, los testimonios de mujeres rurales de distintas partes del globo, demuestran la vigencia de la demanda por tierra. Porque si el acceso constituye un problema para todo el campesinado, lo es aún más para las mujeres" (Ramos y Drago, 2014, p. 136).

Tabla 13. Co-ocurrencias 


\begin{tabular}{|c|c|c|c|c|c|c|c|c|c|c|c|c|}
\hline & $\begin{array}{l}\text { ACCIO } \\
\mathbf{N} \\
\text { SOCIAL } \\
\mathrm{Gr}=11 \\
\end{array}$ & $\begin{array}{l}\text { AMENA } \\
\text { ZAS } \\
\mathrm{Gr}=19\end{array}$ & $\mid \begin{array}{l}\text { CAMPE } \\
\text { SINO } \\
G \mathrm{r}=32\end{array}$ & $\begin{array}{l}\text { ESTIGM } \\
\text { ATIZAC } \\
\text { ION } \\
\text { Gr }=25\end{array}$ & $\begin{array}{l}\text { FORMA } \\
\text { CIÓN } \\
\text { POLÍTI } \\
\text { CA }\end{array}$ & $\begin{array}{l}\text { IDENTI } \\
\text { DAD } \\
\text { Gir }=42\end{array}$ & $\begin{array}{l}\text { LIDERA } \\
\text { ZGO } \\
\mathrm{Gr}=48\end{array}$ & $\begin{array}{l}\text { MACHI } \\
\text { SMO } \\
\text { Gir }=15\end{array}$ & \begin{tabular}{|l|} 
MADRE \\
CABEZ \\
A DE \\
FAMILI
\end{tabular} & \begin{tabular}{|l|} 
MO YIMI \\
ENTO \\
SOCIAL \\
Gr $=46$ \\
\end{tabular} & $\begin{array}{l}\text { MUJER } \\
\text { Gr }=52\end{array}$ & $\begin{array}{l}\text { SINDIC } \\
\text { ATO } \\
\text { Gr }=29\end{array}$ \\
\hline $\begin{array}{l}\text { ACCION SOCIAL } \\
\mathrm{Gi}_{\mathrm{r}}=11\end{array}$ & 0 & 1 & 1 & 1 & ${ }^{7}$ & ${ }^{2}$ & 6 & 1 & 0 & 9 & 3 & 4 \\
\hline $\begin{array}{l}\text { AMENAZAS } \\
\mathrm{Gr}=19\end{array}$ & 1 & 0 & 6 & 18 & 2 & 1 & 4 & 1 & 0 & 3 & 4 & 4 \\
\hline $\begin{array}{l}\text { CAMPESINO } \\
\mathrm{Gr}=32\end{array}$ & 1 & 6 & 0 & $7 \mid$ & 9 & 22 & 8 & 5 & 2 & 9 & 17 & 6 \\
\hline $\begin{array}{l}\text { ES TIGMATIZACION } \\
\mathrm{Gi}_{\mathrm{r}}=25\end{array}$ & 1 & ${ }^{18}$ & 7 & 0 & 3 & 3 & 5 & 8 & 1 & 4 & 6 & 4 \\
\hline $\begin{array}{l}\text { FORMACIÓN } \\
\text { POLĹTICA }\end{array}$ & 7 & 2 & 9 & 3 & 0 & 14 & 26 & ${ }^{2}$ & 2 & ${ }^{28}$ & 20 & 21 \\
\hline $\begin{array}{l}\text { IDENTIDAD } \\
\mathrm{Gi}=42\end{array}$ & 2 & 1 & 22 & 3 & 14 & 0 & 17 & 4 & 4 & 14 & 26 & 7 \\
\hline $\begin{array}{l}\text { LIDERAZGO } \\
\mathrm{Gr}=48\end{array}$ & 6 & 4 & 8 & 5 & ${ }^{26}$ & 17 & 0 & 3 & 4 & 22 & 21 & 10 \\
\hline $\begin{array}{l}\text { MACHISMO } \\
\mathrm{Gi}=15\end{array}$ & 1 & 1 & 5 & 8 & 2 & 4 & 3 & 0 & 0 & 4 & 10 & 2 \\
\hline $\begin{array}{l}\text { MADRE CABEZA DE } \\
\text { FAMILIA } \\
\text { Gir }=9\end{array}$ & 0 & 0 & 2 & 1 & 2 & 4 & 4 & 0 & 0 & 3 & 4 & \\
\hline $\begin{array}{l}\text { MOYIMIENTO } \\
\text { SOCIAL }\end{array}$ & 9 & 3 & 9 & 4 & 28 & 14 & 22 & 4 & 3 & 0 & 19 & 21 \\
\hline $\begin{array}{l}\text { MUJER } \\
\mathrm{Gr}=52\end{array}$ & 3 & 4 & 17 & 6 & 20 & 26 & 21 & 10 & 4 & 19 & 0 & 10 \\
\hline $\begin{array}{l}\text { SINDICATO } \\
\mathrm{Gi}=29\end{array}$ & 4 & ${ }^{4}$ & 6 & ${ }^{4}$ & 21 & 1 & ${ }^{10}$ & 4 & & 21 & 10 & 0 \\
\hline
\end{tabular}

Fuente: elaboración propia con base en las entrevistas.

Como se puede evidenciar en la tabla de co-ocurrencias, existe una fuerte relación entre las amenazas y estigmatizaciones, 18 veces fueron nombradas estas categorías relacionadas entre sí. Aunque es importante mencionar que la estigmatización no está dada sólo por su rol como lideresas, sino además por el hecho de ser mujeres en un escenario históricamente patriarcal. Como se puede evidenciar, solo en 2020 han sido asesinadas más de 27 lideresas, de las cuales el 37.03\% son mujeres indígenas y el 29.7\% lideresas comunales campesinas. Esto demuestra que existe un especial énfasis en acabar con los liderazgos que defienden a nivel veredal y local el territorio, la vida y que apoyan abiertamente los procesos de restitución de tierras y la implementación de los acuerdos de La Habana, así como rechazan megaproyectos que transformarían las configuraciones territoriales en favor de la profundización del modelo neoliberal 
Tabla 14. Lideresas sociales asesinadas en el año 2020.

\begin{tabular}{|c|c|c|c|c|}
\hline NOMBRE & FECHA & MUNICIPIO & DEPARTAMENTO & SECTOR SOCIAL \\
\hline $\begin{array}{l}\text { GLORIA } \\
\text { ISABEL } \\
\text { OCAMPO }\end{array}$ & $07 / 01 / 2020$ & $\begin{array}{l}\text { PUERTO } \\
\text { GUZMAN }\end{array}$ & PUTUMAYO & $\begin{array}{l}\text { CAMPESINA } \\
\text { - COMUNAL }\end{array}$ \\
\hline $\begin{array}{l}\text { VIRGINIA } \\
\text { SILVA }\end{array}$ & $07 / 01 / 2020$ & PAEZ & CAUCA & INDIGENA \\
\hline $\begin{array}{l}\text { MIREYA } \\
\text { HERNÁNDEZ } \\
\text { GUEVARA }\end{array}$ & $08 / 01 / 2020$ & ALGECIRAS & HUILA & COMUNAL \\
\hline $\begin{array}{l}\text { AMPARO } \\
\text { GUEJIA } \\
\text { MESTIZO }\end{array}$ & $10 / 01 / 2020$ & CALOTO & CAUCA & INDIGENA \\
\hline $\begin{array}{l}\text { SANDRA } \\
\text { MAYERLY } \\
\text { BAQUERO }\end{array}$ & $08 / 02 / 2020$ & ARAUCA & ARAUCA & SINDICAL \\
\hline
\end{tabular}




\begin{tabular}{|l|l|l|l|l|}
\hline YURI & $21 / 02 / 2020$ & SEGOVIA & ANTIOQUIA & COMUNAL \\
ALEXANDRA & & & & \\
ORTIZ & & & & \\
\hline LURENO ENEIDA & $08 / 03 / 2020$ & BUENOS & CAUCA & INDIGENA \\
IPIA & & AIRES & & \\
CHOCUE & & & & \\
\hline MARLLY & $27 / 03 / 2020$ & TOTORÓ & CAUCA & INDIGENA \\
FERNANDA & & & & \\
QUINA & & & & \\
CAMPO & & & & \\
\hline OLGA LUCÍA & $21 / 05 / 2020$ & CUMARIBO & VICHADA & COMUNAL \\
HERNÁNDEZ & & & & \\
\hline MARIA & $29 / 05 / 2020$ & CORINTO & CAUCA & \\
NELLY & & & & \\
\hline CUETIA & & & & \\
\hline DAGUA & & & & \\
\hline ANGELITENA & & & \\
\hline
\end{tabular}




\begin{tabular}{|c|c|c|c|c|}
\hline $\begin{array}{l}\text { ROSALBINA } \\
\text { BECOCHE } \\
\text { YANDI }\end{array}$ & $27 / 06 / 2020$ & MORALES & CAUCA & CAMPESINA \\
\hline $\begin{array}{l}\text { POLA DEL } \\
\text { CARMEN } \\
\text { MENA }\end{array}$ & $05 / 07 / 2020$ & EL TAMBO & CAUCA & AFRODESCENDIENTE \\
\hline $\begin{array}{l}\text { SONIA } \\
\text { BISBICUS } \\
\text { ORTIZ }\end{array}$ & $27 / 07 / 2020$ & BARBACOAS & NARIÑO & INDÍGENA \\
\hline $\begin{array}{l}\text { LUISA } \\
\text { AVILA } \\
\text { HENAO }\end{array}$ & $03 / 08 / 2020$ & BUGA & $\begin{array}{ll}\text { VALLE } & \text { DEL } \\
\text { CAUCA } & \end{array}$ & LGBTIQ+ \\
\hline $\begin{array}{l}\text { NATHALIA } \\
\text { ANDREA } \\
\text { PERLAZA }\end{array}$ & $21 / 08 / 2020$ & PALMIRA & $\begin{array}{l}\text { VALLE } \quad \text { DEL } \\
\text { CAUCA }\end{array}$ & AFRODESCENDIENTE \\
\hline $\begin{array}{l}\text { RITA } \\
\text { RUBIELA } \\
\text { BAYONA } \\
\text { ALFONSO }\end{array}$ & $25 / 08 / 2020$ & $\begin{array}{l}\text { SANTA } \\
\text { MARTA }\end{array}$ & MAGDALENA & COMUNAL \\
\hline $\begin{array}{l}\text { OMAIRA } \\
\text { ALCARÁZ }\end{array}$ & $29 / 08 / 2020$ & SAN PABLO & BOLÍVAR & COMUNAL \\
\hline
\end{tabular}




\begin{tabular}{|c|c|c|c|c|}
\hline $\begin{array}{l}\text { SANDRA } \\
\text { BANDA } \\
\text { MENESES }\end{array}$ & $31 / 08 / 2020$ & TARAZÁ & ANTIOQUIA & COMUNAL \\
\hline $\begin{array}{l}\text { PAULA } \\
\text { YANIRA } \\
\text { BISBICUS }\end{array}$ & $16 / 09 / 2020$ & TUMACO & NARIÑO & INDÍGENA \\
\hline $\begin{array}{l}\text { ALEXANDRA } \\
\text { CUESTAS }\end{array}$ & $20 / 09 / 2020$ & MALLAMA & NARIÑO & INDÍGENA \\
\hline $\begin{array}{l}\text { ANA LUCÍA } \\
\text { BISBICÍUS } \\
\text { GARCÍA }\end{array}$ & $03 / 10 / 2020$ & BARBACOAS & NARIÑO & INDÍGENA \\
\hline REINA MERA & $12 / 10 / 2020$ & SUAREZ & CAUCA & INDÍGENA \\
\hline $\begin{array}{l}\text { MARLY LUZ } \\
\text { PÉREZ }\end{array}$ & $13 / 10 / 2020$ & EL BAGRE & ANTIOQUIA & CAMPESINO \\
\hline $\begin{array}{l}\text { JUANA } \\
\text { PEREA } \\
\text { PLATA }\end{array}$ & $28 / 10 / 2020$ & NUQUí & CHOCÓ & AMBIENTALISTA \\
\hline $\begin{array}{l}\text { ROCÍO } \\
\text { ALOMÍA } \\
\text { MANTILLA }\end{array}$ & $01 / 11 / 2020$ & $\begin{array}{ll}\text { LÓPEZ } & \text { DE } \\
\text { MICAY } & \end{array}$ & CAUCA & AFRODESCENDIENTE \\
\hline
\end{tabular}

Fuente: elaboración propia, con datos de diferentes medios de comunicación. 
El proceso político dentro de FENSUAGRO es uno de los pilares fundamentales para fortalecer la militancia y el horizonte político de la base social. Por tal razón, las MLC entrevistadas señalan la relación directamente proporcional entre el pertenecer a un movimiento como FENSUAGRO y su proceso formativo tanto en lo político, en lo organizacional, en lo jurídico y en la defensa de sus derechos teniendo como referente la triple identidad: mujer, lideresa y campesina.

Sin embargo, como se evidencia en la categoría de identidad en la tabla, el proceso de reconocimiento y auto reconocimiento parte de la base de la formación política y de la ruptura de las estructuras de poder y dominación propias del ejercicio del machismo y la masculinización de los espacios donde las mujeres han asumido roles de liderazgo y de direccionamiento de la vida propia y comunitaria. Por tal razón, la categoría de movimiento social tiene una correlación directa y fuerte entre las categorías de liderazgo, identidad y formación política. El hecho de pertenecer a una organización que brinda redes de apoyo, así como redes de conocimiento, es sin lugar a duda una ventaja para quienes han sufrido históricamente diferentes tipos de violencia. 


\section{CONCLUSIONES}

"La verdad es que toda la historia de América puede leerse como una larga guerra entre las fuerzas de la dignidad; y las que nos niegan la posibilidad de ser voces, nos condena a ser ecos, nos niegan la posibilidad de tener cuerpo propio y nos obligan a ser sombra de otros".

Eduardo Galeano

En la presente tesis se ha realizado un recorrido por la historia del campesinado en Colombia y el papel preponderante de la mujer entre los años 2002 y 2020, como ha venido dándose su organización en el reclamo de sus derechos y la toma de decisiones estratégicas que las han llevado al empoderamiento de sus acciones de vida; además el papel que ha tenido la Federación Nacional Sindical Agropecuaria -FENSUAGRO- para la realización de tales proyectos.

De ahí que el empoderamiento de estas mujeres ha demostrado no solo a ellas, sino también a sus comunidades, los valiosos aportes que se pueden llevar acabo cuando estas mujeres deciden tomar el control de sus acciones. Acciones que han venido presentándose en muchas esferas y en este trabajo puntualmente a través de las agrupaciones sindicales, en la cual participan también los jóvenes y hombres campesinos, pero que como mujeres 
campesinas han venido liderando y ganando espacio de participación en la defensa y reconocimiento de sus derechos, por la defensa de la tierra, por su participación política, por su acción colectiva campesina y por ser lideresas agremiadas a un sindicato.

La investigación también se ha centrado en ahondar en los procesos sociales, políticos y económicos de la historia colombiana en los cuales se han visto insertas las mujeres campesinas. Paralelamente mirar como Colombia ha estado enmarcada desde los años sesenta, en políticas donde se puede evidenciar claramente la inequidad, no solo en la tenencia de la tierra, sino en la participación democrática, con políticas excluyentes para las mujeres que luchan día a día por sobrevivir en una historia enmarcada por la muerte.

Ahora bien, en este mismo sentido, se inicia con una descripción del Plan Colombia y la política de Seguridad Democrática. En este apartado se analizan los impactos en términos de violaciones de DD.HH. y el aumento de los desplazamientos masivos. De igual manera, se analiza el impacto del fenómeno paramilitar, la parapolítica y la desmovilización de las Autodefensas Unidas de Colombia (AUC). Luego, se aborda el cambio de gobierno y las perspectivas que éste trajo con un incipiente proceso de paz, para finalizar con los resultados en materia de disminución del conflicto y las nuevas perspectivas.

Dentro de este contexto de violencia, en el marco del conflicto armado, la mujer campesina se ha visto violentada de manera directa en varias formas (sexual, laboral, social y familiar). Sin embargo muchas de estas mujeres nos muestran las distintas miradas a través de sus experiencias de vida, sus aportes y su papel protagónico dentro del desarrollo de los mismos, convirtiéndose en lideresas en su comunidad y un ejemplo para muchas más. 
En ese sentido, este trabajo también busca reflejar el papel de la Federación Sindical Nacional Agropecuaria (FENSUAGRO) en el reconocimiento de la mujer como protagonista en su vida social, económica, política y familiar desde su estatus de mujer campesina; destacando la lucha por la defensa de los derechos humanos y a su vez buscando la visibilización de una política de género, su resiliencia y aporte a su comunidad. Como interés investigativo resaltamos experiencias de mujeres que han protagonizado eventos que marcan aconteceres históricos desde su posicionamiento en la defensa de la política de género y su reconocimiento como protagonista de una sociedad. Mostrando a su vez cómo la influencia de estas acciones se generaliza dando como resultado una masiva participación de la mujer desde el campo. Se resalta el esfuerzo de las prácticas organizativas de las mujeres rurales y los grandes obstáculos que tienen que enfrentar para sobrevivir en una organización.

En el documento se hace recorrido groso modo de los procesos socio- económicos del sector agrario desarrollados en Colombia entre los periodos 2002-2020, haciendo hincapié en las políticas emanadas desde el Estado, el conflicto armado y la mujer campesina. Con el propósito de identificar y resaltar el papel de instrumentos gremiales y políticos que han apoyado a la reivindicación de los derechos de la mujer, como lo ha hecho FENSUAGRO. Vemos como de una manera puntual las mujeres agremiadas han ejercido un empoderamiento eficaz en temas como reivindicación de derechos, soberanía alimentaria y defensa de la tierra, que a través de talleres, reuniones y pequeños emprendimientos, grupos de mujeres lideresas en sus comunidades ha difundido lo que han ido construyendo y aprendiendo en las diferentes organizaciones sindicales inscritas a FENSUAGRO.

A lo largo del estudio realizado, se puede concluir que en Colombia se ha vivido una violencia que ha existido siempre entre los conflictos armados y las guerras civiles, dejando 
como saldo incontables muertes, desapariciones forzadas a lo largo de la historia de nuestra República, llegando incluso a ser ya naturalizada en el imaginario de las distintas generaciones. Puntualmente vemos, que en la política del gobierno "Política de seguridad Democrática" las mujeres que en muchos casos fueron víctimas de violación como táctica de guerra y en otros de desplazamiento, forman parte de la ya larga lista de denuncias que se hicieron al respecto frente a la Corte Suprema de Justicia, junto con la muerte de muchos jóvenes, hijos de estas mujeres que fueron dados como falsos positivos. Las políticas de gobierno del ex presidente Álvaro Uribe Vélez, quien consolida el sistema de Seguridad Democrática, aún son tema de muchos trabajos de investigación, de denuncias a nivel internacional y de gran indignación. Aún se sigue cuestionado hasta nuestros días, por tener como consecuencias un accionar de autoritarismo del poder, basado en la política del desconocimiento a los derechos humanos. La no distinción entre civiles y combatientes dieron como resultado miles de muertes como anteriormente lo mencionábamos denominadas como "falsos positivos", desplazamientos forzados de indígenas y comunidades campesinas de sus tierras, generando a su paso desolación y muerte. En este contexto la mujer campesina es blanco de muchas injusticias y principal víctima del conflicto armado.

La generalizada violencia en el país ha desembocado innumerables abusos contra las mujeres rurales, aumentando los niveles de discriminación, pobreza y vulnerabilidad de las mismas, que al quedar estas viudas y violentadas sexual y emocionalmente buscan en el desplazamiento una oportunidad de vida, dejando atrás sus propiedades, su cultura y su riqueza ancestral. 
La lucha histórica de las mujeres campesinas, indígenas y afrodescendientes en la sociedad colombiana por lograr un espacio de heterogeneidad y reconocimientos tanto políticos, social y económicos, han sido de larga data, no obstante, estas mujeres han logrado alcanzar un posicionamiento en la producción del campo, que apunta en la reproducción de la fuerza de trabajo. Pese a todo esto, aunque existe el Plan Nacional de Desarrollo (20142018) en el que se declaman políticas encaminadas a la mujer rural, el estado aun no muestra políticas claras en cuanto a las líneas relacionadas con proyectos o programas encaminados a la generación de oportunidades y recursos, y solo unos pocos programas de manera indirecta generan recursos residuales, limitados e insuficientes que no hacen presencia en todos los sitios donde se necesita.

Producto de los resultados de esta investigación me atrevo a pensar algunos posibles campos de acción. En este sentido las políticas de Estado podrían trabajar en conjunto o de manera integrada con los sindicatos agrarios, para lograr la sostenibilidad en los procesos alcanzados por FENSUAGRO en el camino de posicionar a la mujer, para que ésta logre enfrentar los cambios sociales; y que en el ejercicio de la democracia el Estado logre identificar las múltiples necesidades e intereses del sector campesino con el propósito de sostener a las mujeres como actoras sociales. En Colombia donde a lo largo de su historia gran parte de la economía giraba en torno a la producción agraria, y sus múltiples y fallidas reformas agrarias que dieron origen a muchos conflictos como lo expuesto en esta tesis, FENSUAGRO ha hecho una apuesta por la participación de la mujer campesina, donde pretende hacer un cambio, garantizando la participación y el empoderamiento de la mujer. Las mujeres que están agremiadas en este sindicato hacen presencia activa, participando de manera eficiente no solo en la organización y apoyo de la organización, sino en la 
representación de la misma por medio de proyectos y propuestas en la preservación del medio ambiente, la defensa en la producción sana de alimentos, la soberanía alimentaria , la preservación de semillas originarias y el derecho a la protección de sus tierras.

Es a través de acciones de reconocimiento como sujetas políticas de derechos, en donde se evidencia y reconocen sus capacidades dentro de una organización política de formación campesina permanente. De acuerdo con esto puedo señalar que FENSUAGRO contribuye a desarrollar políticas de trabajo sobre el feminismo campesino y popular por medio de la Vía Campesina, la cual va fortaleciendo la participación equitativa y de género de la mujer. Si se tiene en cuenta que estamos inmersos en una cultura patriarcal y machista que a lo largo de la historia ha negado y en ocasiones satanizado la participación de la mujer, esta organización ha desarrollado múltiples actividades para que esta inequidad tienda a desaparecer. Por esta razón, al hacer procesos de formación a la mujer campesina da como resultado la concientización y valoración de su participación en todos los campos sociales.

Por esta razón es importante destacar que las políticas de género podrían articular las capacidades de negociación de la mujer, permitiendo la permanencia de las mismas en cargos que representen responsabilidad y de esta manera que se le continúe apreciando en estructuras jerárquicas donde puedan demostrar sus capacidades a fin de incrementar una práctica democrática y organizada. Como se puede observar en la tesis, es necesario mantener y ajustar las políticas sociales con el objetivo de encontrar más presencia femenina en la toma de decisiones fundamentales de los aconteceres rurales. Intentando mantener una política de seguridad y protección a las lideresas y sus organizaciones con el único fin de garantizar la seguridad de la vida. 
Asimismo, tal como las propias lideresas entrevistadas lo dicen, se hace necesario a nivel macro social cerrar la brecha de las inequidades que enfrenta la sociedad colombiana en cuanto a las carencias del campo y a su vez poner freno a la violencia y que fractura la estabilidad de la sociedad campesina. Mientras que es menester en el espacio político mantener las políticas de apoyo desde las federaciones que generan igualdad de oportunidades, respeto, siendo además medios de concertación encaminados a una mejor proyección de la mujer del campo.

Por estas razones es necesario poner en marcha las siguientes propuestas, que nacen de estas mujeres sindicalizadas y de su arduo trabajo. Para ellas no son solo una iniciativa más, sino un acto de reivindicación de la mujer en todos los campos pero especialmente en la mujer campesina, pero sin olvidar que también se hace necesario trabajar de manera conjunta con las políticas del estado y todas las organizaciones sindicales como una apuesta para el reconocimiento de las mujeres en los siguientes frentes:

- Generando políticas claras enfocadas a la protección de la mujer para protegerlas de las situaciones de guerra y protección especial para las mujeres víctimas de la violencia.

- Reconociendo y visibilizando los aporte económicos y productivos de las mujeres en el campo y el aporte significativo a su de trabajo.

- Velando por la protección del papel de las mujeres en la construcción de su identidad y su cultura, en la defensa permanente de la integridad de las comunidades y como gestoras de vida. 
- Tomando medidas concretas encaminadas a erradicar la discriminación hacia las mujeres campesinas, desarrollando acciones positivas de reparación integral por la discriminación histórica y social que tiendan a una efectiva equidad de género.

- Dando las garantías de participación y toma de decisiones a las mujeres campesinas por parte del estado en cuanto a la planeación, gestión y ejecución de proyectos que involucren sus tierras, su economía y sus medios de producción.

- Haciendo veeduría y protección especial y efectiva para las mujeres del campo cabezas de hogar.

Para concluir, luego de haber tomado puntos neurálgicos y de haber entrevistado y conocido a estas mujeres, se puede decir que: son referentas de otras mujeres líderes campesinas; hijas de campesinos, algunas de ellas integrantes de los sindicatos desde muy jóvenes por su vínculo familiar; estructuradas en la política sindical; mujeres que luchan para ser escuchadas porque saben que están inmersas en un sistema patriarcal; que demuestran a cada momento su fortaleza y dedicación dentro de las agremiaciones sindicales en las que hacen parte y que con un alto nivel de resiliencia enfrentan su vida.

Por último, solo me resta decir que no tengo más que admiración y agradecimiento por lo que hacen y por la manera en que nos demuestran que con voluntad, tesón y amor se puede sobrellevar cualquier dificultad y que nunca se debe perder la esperanza de poder vivir en un país mejor, donde ellas y sus familias puedan alcanzar una equidad de género y garantías para su vida.

\section{BIBLIOGRAFÍA}


Agencia Prensa Rural. (2014). Primer aniversario del paro campesino del Catatumbo. Recuperado de: https://www.prensarural.org/spip/spip.php?article14390.

Ahumada, M. (s.f) El enemigo interno en Colombia. Quito Ediciones Abya Yala. ISBN: 978-9978-22-655-1.

Archila M. (2018). Idas y Venidas, Vueltas y Revueltas. Editores Siglo del Hombre, segunda edición. pág. 236-394.

Bello, M. (2003). El desplazamiento forzado en Colombia: acumulación de capital y exclusión social. Revista Aportes Andinos No 7. Blu Radio. (2018). Falsos positivos serían más de 10.000, según coronel retirado. Recuperado de: https://www.bluradio.com/nacion/falsos-positivos-serian-mas-de-10000-segun-coronelretirado-177800-ie435. , C. (2017). Mujeres rurales en Colombia. Recuperado de: https://www.landcoalition.org/sites/default/files/documents/resources/20171001.informe_m ujeresruralesCadavid Rico, M. (2014). Mujer: blanco del conflicto armado en Colombia. Analecta polit, Vol. 4, No. 7, pp. 301-318.

Cangiano, María. Lindsay Dubois. De Mujer a Género. Teoría, interpretación y práctica feminista en las Ciencias Sociales. Centro Editor de América Latina.

Camargo, E. (2010). La seguridad democrática: otro falso positivo. Recuperado de: https://www.colectivodeabogados.org/La-seguridad-democratica-otro.

Castaño González, Eugenio. (2019). DEL ÉXODO HUMANO A LA SUPERVIVENCIA ORGANIZADA. Memoria histórica Sintraproaceites (seccionales San Alberto y El Copey), 
Sintrainagro (seccional Minas), Sintragrim (seccionales El Castillo y Mesetas), 1970-2018. Escuela Nacional Sindical. ISBN: 978-958-8207-76-6.

Centro Nacional de Memoria Histórica. (2014). La tierra en disputa. Memorias del despojo y resistencias campesinas en la costa Caribe 1960-2010. Recuperado de: http://www.centrodememoriahistorica.gov.co/descargas/informes2010/tierra_conflicto/la_ti erra_en_\%20disputa.pdf.

Centro Nacional de Memoria Histórica. (2014). La tierra en disputa. Memorias del despojo y resistencias campesinas en la costa Caribe 1960-2010. Recuperado de: http://www.centrodememoriahistorica.gov.co/descargas/informes2010/tierra_conflicto/la_ti erra_en_\%20disputa.pdf.

Centro Nacional de Memoria Histórica. (2014). La tierra en disputa. Memorias del despojo y resistencias campesinas en la costa Caribe 1960-2010. Recuperado de: http://www.centrodememoriahistorica.gov.co/descargas/informes2010/tierra_conflicto/la_ti erra_en_\%20disputa.pdf.

Centro Nacional de Memoria Histórica. (2015). Desmovilización y reintegración paramilitar. Panorama posacuerdos con las AUC. ISBN: 978-958-8944-03-6.

Clavijo, R; Giraldo, M y Ballén, L. (2019). Aproximación al problema de la tenencia de la tierra en Colombia: de la negociación en la mesa de La Habana al Medio Ariari. En: Huellas del Desarrollo: Intersecciones entre Conflicto, Reconfiguración Social y Pacificación en Colombia. Editorial USTA.

Colectiva Juana Julia Guzmán. (s.f). Juana Julia Guzmán. Recuperado de: http://lasjuanas.blogspot.com/p/juana-julia-guzman.html. 
Colectiva Juana Julia Guzmán. (s.f). Juana Julia Guzmán. Recuperado de: http://lasjuanas.blogspot.com/p/juana-julia-guzman.html.

Comisión Colombiana de Juristas. (2011). La política agraria y los derechos de las mujeres en Colombia.

Comité de la Convención para la Eliminación de todas las formas de discriminación contra la mujer -CEDAW-. (2019). Primer informe sombra específico de mujeres rurales y campesinas en Colombia.

Comité de la Convención para la Eliminación de todas las formas de discriminación contra la mujer -CEDAW-. (2019). Primer informe sombra específico de mujeres rurales y campesinas en Colombia.

Consultoría para los Derechos Humanos y el Desplazamiento. (2013). El desplazamiento forzado en Colombia: La huella del conflicto. Recuperado de: http://www.codhes.org/ codhes/images/Articulos/AnalisisSituacionalfinal.pdf.

Deere, C y León, M. (2002). La brecha de género en la propiedad de la tierra en América Latina. Estudios Sociológicos, Vol. 23, No. 68, pp. 397-439.

Deere, C. (2012). Tierra de mujeres: reflexiones sobre el acceso de las mujeres rurales a la tierra en América Latina. ISBN 978-99954-770-4-2

Defensoría del Pueblo. (s.f.). Al menos 555 líderes sociales han sido asesinados entre 2016 y 2019: Defensoría del Pueblo. Recuperado de: https:/www.defensoria.gov.co/es/nube/enlosmedios/8996/Al-menos-555-1\%C3\%ADderessociales-han-sido-asesinados-entre-2016-y-2019-Defensor\%C3\%ADa-del- 
Pueblo.htm\#: :text=El\%20defensor\%20del\%20Pueblo\%2C\%20Carlos,realiza\%201a\%20en tidad\%20que\%20dirige.

Departamento Administrativo Nacional de Estadística. (2014). Censo Nacional Agropecuario. Recuperado de: http://www.dane.gov.co/index.php/estadisticas-portema/agropecuario/censo-nacional-agropecuario-2014.

Díaz Suasa, J. (2002). Situación de la mujer rural colombiana. Perspectiva de género. Cuadernos Tierra y Justicia (9), 1-54.

Díaz, Y. (2020). Comunicación personal.

El colombiano. (2018). A la JEP llegó el caso de los falsos positivos de Soacha. Recuperado de: https:/www.elcolombiano.com/colombia/a-la-jep-llego-el-caso-de-los-falsos-positivosde-soacha-he9143584.

El Espectador. (2008). Del Estatuto de Seguridad a la Seguridad Democrática. Recuperado de: $\quad$ https://www.elespectador.com/impreso/judicial/articuloimpreso-del-estatuto-deseguridad-seguridad-democratica

El Espectador. (2012). El año de las protestas ambientales. Recuperado de: https://www.elespectador.com/noticias/actualidad/vivir/el-ano-de-protestas-ambientalesarticulo-394501.

El Espectador. (2014).¿Por qué se desinfló la MANE? Recuperado de: https://www.elespectador.com/noticias/educacion/se-desinflo-mane-articulo-511062.

El Tiempo. (2003). Colombia alcanzó tasa récord de desplazamiento. Recuperado de: https://www.eltiempo.com/archivo/documento/MAM-1033925. 
El Tiempo. (2009). La condena de Salvador Arana. Recuperado de: https://www.eltiempo.com/archivo/documento/CMS-6744070.

El Tiempo. (2010). Empresarios de la palma, a la cárcel por los desplazamientos en Urabá. Recuperado de: https://www.eltiempo.com/archivo/documento/CMS-7717280.

El Tiempo. (2010). Firman acuerdo de paz con los paramilitares entre 2002 y 2008. Recuperado de: https://www.eltiempo.com/archivo/documento/CMS-8601880.

Erazo, M. I., Jiménez, M. \& López, C. (2014). Empoderamiento y liderazgo femenino; su papel en la autogestión comunitaria en el corregimiento El Hormiguero - Valle del Cauca. Avances en Psicología Latinoamericana, vol. 32(1), pp. 149-157. doi: dx.doi.org/10.12804/apl32.1.2014.10.

Estrada, J. (2002). El Plan Colombia y la intensificación de la guerra: aspectos globales y locales. Bogotá: Universidad Nacional de Colombia.

Fals Borda, O. (1986). Retorno a la tierra. Historia doble de la Costa, Carlos Valencia Editores, tomo IV, Bogotá.

FAO. (s.f.). ¿Qué significa ser mujer rural? Recuperado de: http://www.fao.org/3/ah492s/ah492s01.pdf

FARC-EP y Gobierno de Colombia. (2016). Acuerdo final para la terminación del conflicto y la construcción de una paz estable y duradera. Recuperado de: https:/www.cancilleria.gov.co/sites/default/files/Fotos2016/12.11_1.2016nuevoacuerdofin al.pdf. 
FENSUAGRO. (2018). Memorias de represión, memorias de resistencia. Recuperado de: http://pachakuti.org/IMG/pdf/memorias_de_represion_memorias_de_resistencia__informe_fensuagro.pdf

Fundación Comité de Solidaridad con los Presos Políticos. (2004). Tortura en tiempos de seguridad democrática. Informe.

Fundación Paz y Reconciliación. (2016). Bacrim, neo-paramilitares y grupos postdesmovilización paramilitar. Recuperado de: https://pares.com.co/2016/03/31/bacrimneoparamilitares-y-grupos-post-desmovilizacion-paramilitar/.

Goffman, E., \& Guinsberg, L. (1970). Estigma: la identidad deteriorada. Buenos Aires: Amorrortu.

Guerra, Nuris Martínez, Carlos. Interseccionalidad: concepto adaptable a la realidad étnica de Colombia

Harvey, D. (2005). El nuevo imperialismo. Acumulación por desposesión. ¿Ciudad? CLACSO. Recuperado de: http://biblioteca.clacso.edu.ar/clacso/se/20130702120830/harvey.pdf

Hobsbawm, E. (1994). Identidad. Conferencia inaugural del congreso "Los nacionalismos en Europa: Pasado y presente". Recuperado de: http://espacio.uned.es/fez/eserv/bibliuned:filopoli-1994-3-47805E41-BBF2-4D8F-D9B7-

7AFE6F430F37/identidad.pdf.

Lancheros_col_1.pdf. 
León M. y Deere, C. (1997). La mujer rural y la reforma agraria en Colombia. Cuadernos de Desarrollo Rural, 38 y 39, 7-23.

Mariategui, J. (1918). Siete ensayos de interpretación de la realidad peruana. Ciudad? Editorial Minerva.

Martínez, N. (2020). Comunicación personal.

Márquez, S. (2020). Comunicación personal.

Medina García 2018: 313.

Meertens, D y Sánchez, G. (1983). Bandoleros, gamonales y campesinos. El Áncora editores. Bogotá.

Molano, A. (2012). Paramilitarismo y palma en el Catatumbo. Recuperado de: https://www.elespectador.com/noticias/judicial/paramilitarismo-y-palma-el-catatumboarticulo-330074.

Mondragón, H. (2002). La organización campesina en un ambiente de terror. Recuperado de: https://www.researchgate.net/publication/268275403_La_Organizacion_Campesina_en_un _Ambiente_de_Terror/link/5898a32892851c8bb6802760/download.

Moreno, A. (2020) Comunicación personal.

Movimiento Mundial de los Derechos Humanos. (2004). La "Seguridad Democrática": Desconoce los derechos humanos y socava las bases del Estado de Derecho. Recuperado de: https://www.fidh.org/es/region/americas/colombia/La-Seguridad-Democratica-Desconoce. 
Múnera, L. (1997). Relations de pouvolr et mouvementpopulate en Colombie (1968-1988), üniversité Catholique de Louvain, Instituí d’Études du Développement, L’Hartman, Academia Bruylant, Bélgica.

Muñoz, J. (2003). Aportes para el análisis de la política pública para el desarrollo de la mujer rural de 1994 en Colombia. Cuadernos de desarrollo rural, 50, 97-124.

Lugones, M. (2008). Colonialidad y Género. Tabula Rasa, Bogotá - Colombia, No.9: 73-101, julio-diciembre.

OXFAM Internacional. (2019). Defensoras de derechos agrarios, territoriales y medioambientales en Colombia. Arriesgando la vida por la paz. ISBN 978-1-78748-508-2.

Oxfam. (s.f). El trabajo invisible de las mujeres rurales en Colombia. Recuperado de: https://www.oxfam.org/es/colombia/el-trabajo-invisible-de-las-mujeres-rurales-encolombia.

Ramírez Bacca, Renzo. (2010). Estudios e historiografía del café en Colombia, 1970-2008. Una revisión crítica. Cuadernos de Desarrollo Rural, 7 (64), 13-31.

Ramos, M y Drago, M. (2013). Feminismo y soberanía alimentaria: voces de mujeres rurales del sur. Recuperado de: https://www.mundubat.org/wpcontent/uploads/archivos/201311/mundubat-16-p.pdf\#page=136.

Revista Semana. (2003). Desmovilización de AUC a finales de 2005. Recuperado de: https://www.semana.com/noticias/articulo/desmovilizacion-auc-finales-del-2005/59352-3. 
Revista Semana. (2007) Guía práctica para entender el escándalo de la parapolítica. Recuperado de: https://www.semana.com/on-line/articulo/guia-practica-para-entenderescandalo-para-politica/84455-3.

Revista Semana. (2011). Grito de amor y de protesta. Recuperado de: https://www.semana.com/nacion/articulo/grito-amor-protesta/249276-3.

Revista Semana. (2016). Bacrim, neo-paramilitares y grupos post-desmovilización paramilitar. Recuperado de: https://www.semana.com/opinion/articulo/ariel-avila-bacrimneoparamilitares-y-grupos-post-desmovilizacion-paramilitar/467330.

Revista Semana. (2016). La historia de los 19 soldados que se negaron a cometer falsos positivos. Recuperado de: https://www.semana.com/nacion/articulo/soldados-que-senegaron-a-cometer-un-falso-positivo/554942.

Revista Semana. (2017). El día que iniciaron las conversaciones secretas con las FARC hace cinco años. Recuperado de: https://www.semana.com/nacion/articulo/como-iniciaron-lasconversaciones-entre-las-farc-y-el-gobierno-colombiano-asi-empezo-todo-enrique-santoscalderon/516584.

Revista Semana. (2019). Colombia, el país donde más asesinan defensores ambientales. Recuperado de: https://sostenibilidad.semana.com/impacto/articulo/colombia-el-paisdonde-mas-asesinan-defensores-ambientales-en-el-mundo-hoy/53492

Revista Partido Comunista Colombiano. (2020)

Rey Sabogal, C. (2013). Análisis espacial de la correlación entre cultivo de palma de aceite y el desplazamiento forzado en Colombia. Cuad. Econ., Volumen 32, Número 61, p. 683 718. 
Rodríguez, Pilar. Feminismos Periféricos. I, Género, Etnicidad, Clase y Migración: Interseccionalidad y Pertenencia Translocalizacional. Conferencia impartida por FLOYA ANTHIAS, Catedrática de Sociología de la Oxford Brookes University, en el seminario Sexo, clase y raza, Universidad de Almería, 9 de mayo de 2005.

Ronderos, M. (2014). Guerras recicladas. Una historia periodística del paramilitarismo en Colombia. Editorial Aguilar. Bogotá.

Sánchez, L. (2020). Comunicación personal.

Salcedo, M. (2020). Comunicación personal.

Santos Zarco, L. (2019). Análisis de la Mujer Rural: La Violencia Machista y las Asociaciones Rurales y Feministas. Universidad de Valladolid. Recuperado de: https://uvadoc.uva.es/bitstream/handle/10324/42600/TFG-

G4181.pdf? sequence $=1 \&$ isAllowed $=\mathrm{y}$

Segura, N y Meertens, D. (1997). Desarraigo, género y desplazamiento interno en Colombia. Nueva Sociedad Nro. 148, pp. 30-43.

Sistema Único de Información Normativa. (1948). Decreto 1483 de 1948. Recuperado de: http://www.suin-juriscol.gov.co/viewDocument.asp?id=1295432.

Sotomayor, N. (2010). Formas de resistencia pacífica al conflicto armado en la localidad 20 de Sumapaz. Disertación de maestría. Universidad Distrital Francisco José de Caldas.

Vaicius, I. (2002). Una perspectiva hacia el entendimiento del Plan Colombia. En Estrada J. (comp.), El Plan Colombia y la intensificación de la guerra: aspectos globales y locales. Bogotá: Universidad Nacional de Colombia, pp. 21-31. 
Valencia, M. (2020). Comunicación personal.

Verdad Abierta. (2008). Desmovilización del Bloque Élmer Cárdenas. Recuperado de: https://verdadabierta.com/desmovilizacion-del-bloque-elmer-cardenas/.

Verdad Abierta. (2010). La historia detrás del Pacto de Ralito. Recuperado de: https://verdadabierta.com/la-historia-detras-del-del-pacto-de-ralito/.

Verdad Abierta. (2010). La parapolítica. Recuperado de: https://verdadabierta.com/la-parapolitica-sp-764685506/.

Verdad Abierta. (2010). Condenan al ex senador Castro Pacheco por parapolítica. Recuperado de: https://verdadabierta.com/condenan-al-ex-senador-castro-pacheco-porparapolitica/.

Verdad Abierta. (2011). La palma y los paramilitares en Chocó. Recuperado de: http://www.verdadabierta.com/paraeconomia/3512- la- palma- y- los- paramilitares- enchoco.

Verdad Abierta. (2015).¿Neo-paramilitares o paramilitares? Recuperado de: https://verdadabierta.com/neoparamilitares-o-criminales/.

Verdad Abierta. (2015). Veinte años de una guerra sin límites en Urabá. Recuperado de: https://verdadabierta.com/veinte-anos-de-una-guerra-sin-limites-en-uraba/.

Vuola 2012: 135.

Vuola, 2002: 139.

Weber, M. (1922) (ed 1996). Economía y sociedad. Fondo de Cultura Económica, México. 
Adell, R. y Robles, J. (2000). Reseña de "La construcción de los movimientos sociales". Revista Española de Investigaciones Sociológicas, 39, pp. 357-363.

Arango, C. y Zuluaga, G. Mujeres campesinas: resistencia, organización y agroecología en medio del conflicto armado. Cuadernos de desarrollo rural, 10 (72), 159-180. Bogotá.

Arizpe, L. (1986). Las mujeres campesinas y la crisis agraria en América Latina. Nueva Antropología, 30 (8), pp. 57-65.

Casa de la Mujer. (2007). Análisis socio demográfico de las víctimas del conflicto armado: Brechas de género. Bogotá.

Chetty S. (1996). The case study method for research in small- and médium - sized firms. International small business journal, 15 (1), pp. 73-85. doi.org/10.1177/0266242696151005

Defensoría del Pueblo. (2008). Promoción y monitoreo de los derechos sexuales y reproductivos de mujeres víctimas de desplazamiento forzado con énfasis en violencias intrafamiliar y sexual. Bogotá.

Díaz, D. (1999). Transformación de las relaciones de género en la Asociación Nacional de Usuarios Campesinos de Colombia - Unidad y Reconstrucción, ANUC-UR. Universidad de París I. París.

Eisenhardt, K. M. (1989). Building Theories from Case Study Research, Academy of Management Review, 14 ( 4), pp. 532-550.

Fajardo, D. (2014). Estudio sobre los orígenes del conflicto social armado, razones para su persistencia y sus efectos más profundos en la sociedad colombiana. Comisión Histórica del $\begin{array}{lllll}\text { Conflicto } & \text { y } & \text { sus }\end{array}$ 
http://www.altocomisionadoparalapaz.gov.co/mesadeconversaciones/PDF/Informe $\% 20 \mathrm{Co}$ misi_n $\% 20$ Hist_rica $\% 20 \mathrm{del} \% 20$ Conflicto $\% 20 \mathrm{y} \% 20$ sus $\% 20 \mathrm{~V}$ ctimas. $\% 20 \mathrm{La} \% 20 \mathrm{Habana}$ \%2C\%20Febrero\%20de\%202015.pdf.

Garretón, M. (2002). La transformación de la acción colectiva en América Latina. Revista de la Cepal, 76, pp. 7-24.

Grinnell, R. M. (1997). Sodal work research \& evaluation: Quantitative and qualitative approaches (Sa. ed.). Itaca: E. E. Peacock Publishers.

Harcourt, W. (2010). Desarrollo y políticas corporales. Debates críticos en género y desarrollo. Barcelona: Bellaterra.

https://prensarural.org/spip/spip.php?article2111.

Ibarra, M. (2007). Acciones colectivas de las mujeres en contra de la guerra y por la paz en Colombia. Revista Sociedad y Economía, 13, pp-66-86. Universidad del Valle, Cali.

Laraña, E. (1999). La construcción de los movimientos sociales. Alianza Editorial. Barcelona.

Martínez, P. (2006). El método de estudio de caso. Estrategia metodológica de la investigación científica. Pensamiento y Gestión, 20, pp. 165-193.

Matijasevic, M y Ruíz, A. (2012). Teorías del reconocimiento en la comprensión de la problemática de los campesinos y las campesinas en Colombia. Revista Colombiana de Sociología, 35 (2), pp. 111-137. 
Meertens, D. (1994). Mujer y violencia en los conflictos rurales. Universidad Nacional de

Colombia. $\quad$ Recuperado de: http://bdigital.unal.edu.co/39968/1/Mujer\%20y\%20violencia.pdf.

Melucci, A. (1966). Challenging Codes. Collective Action in the Information Age. Cambridge: Cambridge University Press.

Miller, A. (2005). Palabras y Resistencias de Mujeres del Putumayo en el Contexto del Conflicto Armado Colombiano. Revista de Ciencias Sociales, 12 (37), pp 85-114.

Molano, A. (2014). Fragmentos de la historia del conflicto armado (1920-2010). Comisión Histórica del Conflicto y sus Víctimas. Recuperado de: http://www.altocomisionadoparalapaz.gov.co/mesadeconversaciones/PDF/Informe\%20Co misi_n $\% 20$ Hist_rica $\% 20 \mathrm{del} \% 20$ Conflicto $\% 20 \mathrm{y} \% 20$ sus $\% 20 \mathrm{~V}$ ctimas. $\% 20 \mathrm{La} \% 20 \mathrm{Habana}$ \%2C $\% 20$ Febrero $\% 20 \mathrm{de} \% 202015 . \mathrm{pdf}$.

Mondragón, H. (2002). La organización campesina en un ambiente de terror. Recuperado de: https://www.researchgate.net/publication/268275403/download.

Olson, M. (1985). La lógica de la acción colectiva. Recuperado de: https://ses.unam.mx/docencia/2018II/OlsonMarcur1985 LaLogicaDeLaAccionColectiva.p df.

Prensa Rural. (2009). Qué es y por qué lucha Fensuagro. Recuperado de:

Ramírez, R. (2005). Sociedad, familia y género: El caso de los migrantes y exiliados colombianos en Suecia. Revista de Estudios Sociales, (21), 53-63. 
Revista Semana. (2009). ¿Cuál es la historia de Fensuagro? Recuperado de: https://www.semana.com/nacion/articulo/cual-historia-fensuagro/100690-3

Sampieri, R. et al. (2006). Metodología de la investigación. MacGraw-Hill Interamericana editores. México D.F.

Segura, N; Meertens, D. (1997). Desarraigo, género y desplazamiento interno en Colombia. Nueva Sociedad, 148, pp 30-43.

Siliprandi, E. (2010). Mujeres y agroecología. Nuevos sujetos políticos en la agricultura familiar. Investigaciones feministas, 1, pp. 125-137.

Strauss, A. y Corbin, J. (2002). Bases de la investigación cualitativa. Técnicas y procedimientos para desarrollar la teoría fundamentada. Editorial Universidad de Antioquia.

Suelt-Cock, V. (2017). Tierra y género. Dilemas y obstáculos en los procesos de negociación de la política de tierras en Colombia. Universitas Humanística, 84 (84). https://doi.org/10.11144/Javeriana.uh84.tgdo.

Touraine, A. (1987). El regreso del actor. Reseña. Recuperado de: https://s3.amazonaws.com/academia.edu.documents/32662537/207178370.Touraine _Los_movimientos_sociales_objeto_particular_o o problema_central_del_analisis_sociolog ico.pdf?AWSAccessKeyId=AKIAIWOWYYGZ2Y53UL3A\&Expires=1536884401\&Signa $\underline{\text { ture= }=\text { yfd3HKGSwS\%2F8389TokNiqnOwM5s\%3D\&response-content- }}$ disposition $=$ inline $\% 3 \mathrm{~B} \% 20 \mathrm{filename} \% 3 \mathrm{D} 207178370$ Touraine _Los_movimientos_soc.pdf 
